\author{
Monograph \\ urn:lsid:zoobank.org:pub:618B3AFF-6EA5-4803-BA7B-A3446CEF3F85
}

\title{
Systematics of the enigmatic South American Streblopus Van Lansberge, 1874 dung beetles and their transatlantic origin: a case study on the role of dispersal events in the biogeographical history of the Scarabaeinae (Coleoptera: Scarabaeidae)
}

\author{
Mario CUPELLO ${ }^{1, *}$, Cibele S. RIBEIRO-COSTA ${ }^{2}$ \& Fernando Z. VAZ-DE-MELLO ${ }^{3}$ \\ 1,2 Universidade Federal do Paraná, Departamento de Zoologia, \\ Laboratório de Sistemática e Bioecologia de Coleoptera, Centro Politécnico, \\ Jardim das Américas, CEP 81531-980, Curitiba, PR, Brazil. \\ ${ }^{3}$ Universidade Federal de Mato Grosso, Instituto de Biociências, Departamento de Biologia e \\ Zoologia, Av. Fernando Correa da Costa, 2367, Boa Esperança, Cuiabá, MT, 78060-900, Brazil. \\ ${ }^{1,2,3}$ Fellow of the Conselho Nacional de Desenvolvimento Científico e Tecnológico (CNPq). \\ *Corresponding author: mcupello@hotmail.com \\ ${ }^{2}$ Email: cibele.ribeirocosta@gmail.com \\ ${ }^{3}$ Email: vazdemello@gmail.com \\ ${ }^{1}$ urn:lsid:zoobank.org:author:BDB03C18-7095-4EAA-8BDD-03CB4F79676D
${ }^{2}$ urn:Isid:zoobank.org:author:1FCBEC2D-0ECE-4863-A9B6-C280193CA320
${ }^{3}$ urn:1sid:zoobank.org:author:2FF2B7D6-1A6B-43C1-9966-A1A949FB2B05
}

\begin{abstract}
Streblopus Van Lansberge, 1874 has been one of the most mysterious dung beetle groups of the Neotropical fauna, having a rather peculiar morphology, very few known specimens in collections and a difficult placement among the scarabaeine lineages. In this work, based on the examination of a recently collected series of specimens and a synthesis of some scattered, but deeply valuable, information available in the literature, we readdress many of the questions posed by past authors. It is shown that Streblopus is a relict genus composed of two currently living species of widely disjunct distribution, namely S. opatroides Van Lansberge, 1874, from patches of Atlantic Forest in the Brazilian states of Bahia and Espírito Santo, and S. punctatus (Balthasar, 1938), known from a few localities across SubAndean humid forests in the Peruvian and Ecuadorian Amazon Forest. We redescribe both and present in detail the evidence pointing to their validity as two independent species; a discussion of their remarkable sexual dimorphism is also given. The biogeography of Streblopus in South America is addressed, and we conclude that the present disjunct distribution of the genus is a consequence of the retreat of the tropical forest corridors that once connected the Atlantic Forest to the Amazon Basin through the South American Dry Diagonal during several periods of the Neogene, particularly until the Middle Miocene. Finally, we propose an African origin for the genus based on its close phylogenetic relationship with a group of Old World taxa - particularly Circellium Latreille, 1825 and Scarabaeini. Having diverged from those groups in the late Upper Cretaceous, we argue that the ancestor of Streblopus arrived in South America crossing the Atlantic Ocean by rafting. We present a synthesis of data from a wide variety of biological groups to support our ideas and contend that long-distance dispersal hypotheses should be taken more seriously by scarab beetle specialists.
\end{abstract}


Keywords. Africa, Atlantic Ocean, rafting, Circellium, Scarabaeini.

Cupello M., Ribeiro-Costa C.S. \& Vaz-de-Mello F.Z. 2020. Systematics of the enigmatic South American Streblopus Van Lansberge, 1874 dung beetles and their transatlantic origin: a case study on the role of dispersal events in the biogeographical history of the Scarabaeinae (Coleoptera: Scarabaeidae). European Journal of Taxonomy 603: 1-85. https://doi.org/10.5852/ejt.2020.603

\section{Introduction}

There is probably nowhere else in the world where the dung beetle fauna has been as intensively studied over the past decades as in the New World, particularly in the Neotropics. Chief among the aspects under investigation is the systematics of Neotropical taxa, as discussed in detail elsewhere (Vaz-de-Mello \& Cupello 2018). While the majority of these dung beetle groups have their more immediate phylogenetic relationships and biogeographical origin well understood, some few, but remarkable genera are yet completely mysterious as to their evolutionary history.

Although the highly speciose and widely distributed genera Cryptocanthon Balthasar, 1942, Bdelyrus Harold, 1869, Canthonella Chapin, 1930, Ontherus Erichson, 1947 and especially Eurysternus Dalman, 1824 could be listed among those puzzling groups, the most interesting cases concern some small, relictually distributed genera such as the monotypic Eudinopus Burmeister, 1840, endemic to open habitats in southern Bolivia and Argentina (Halffter \& Martínez 1966; Vidaurre et al. 2009), Attavicinus Philips \& Bell, 2008, from Mexico (Philips \& Bell 2008), and Bolbites Harold, 1868, from the Chacoan and Pampas grasslands from Bolivia south to Argentina and Uruguay (Vaz-de-Mello \& Grossi 2010), as well as the oligodiverse Anoplodrepanus Simonis, 1981, endemic to Jamaica (Matthews 1966; Howden 1976; Simonis 1981), Bdelyropsis Vulcano et al., 1960, from Central America and Venezuela (Howden 1971, 1976), Canthochilum Chapin, 1934, from the Antilles (Matthews 1966; Philips \& Ivie 2008), Tesserodoniella Vaz-de-Mello \& Halffter, 2006, from Chile (Vaz-de-Mello \& Halffter 2006), Streblopus Van Lansberge, 1874, from South American tropical forest habitats (Halffter \& Martínez 1966), and Zonocopris Arrow, 1932, a giant snail phoretic from South American open environments (Vaz-de-Mello 2007a).

Over the years, different authors have attempted to investigate the systematics of some of these isolated genera, and a general picture has emerged suggesting that many of them are in fact more closely related to groups distributed outside the American continent and, therefore, represent cases of either very ancient vicariant events, long-distance dispersals or relict distributions of once widely distributed taxa. The ancestors of the six New World species of Oniticellini, for instance, seem to have reached the continent from the Old World at different moments during the Cenozoic either via land-bridge range expansion through Beringia (for the continental species in the United States and Mexico, and with subsequent extinction of populations in several parts of Asia and North America) or possibly via transoceanic dispersal between Africa and the Caribbean (Zunino 1982; Philips \& Bell 2008; Philips 2016).

For Tesserodoniella, on the other hand, it has been hypothesized that the genus is closely associated with two Australian taxa, namely Tesserodon Hope, 1837 and Aptenocanthon Matthews, 1974, and this interesting distributional pattern would add to a vast body of known instances of affinities between Australasian and Southern South American elements (Vaz-de-Mello \& Halffter 2006). Indeed, Halffter \& Martínez (1967) and Matthews (1974) had already put forward the idea that many other dung beetle groups in the Australasian and Neotropical regions (besides some other isolated oceanic locations, such as the island of Mauritius) were more closely related to one another than to other taxa on their own continents, and Montreuil's Epilissini hypothesis (Montreuil 2010) is based on this very same premise (but also including groups in Africa and Southeast Asia). It should be noted, however, that many of these 
CUPELLO M. et al., Systematics of Streblopus and dung beetle biogeography

hypotheses do not find support in more recent phylogenetic studies of the dung beetle lineages based either on morphological (Tarasov \& Génier 2015; Tarasov et al. 2016) or on molecular data (Tarasov \& Dimitrov 2016). Nevertheless, these latter studies themselves found a multitude of transcontinental relationships among closely related groups that are likewise worthy of closer scrutiny.

Given that the dung beetles probably first evolved in Africa (Monaghan et al. 2007; Sole \& Scholtz 2010) during the Lower Cretaceous or late Upper Jurassic ( 116-152 million years ago, Gunter et al. 2016; but see Sole \& Scholtz 2010, Ahrens et al. 2014 and Davis et al. 2017 for diverging views), one might readily think that the disjunct distribution of any group of closely related lineages distributed across the southern hemisphere continents is the result of a very early vicariant event related to the breakup of Gondwana (e.g., Tarasov \& Génier 2015). Nevertheless, while this may indeed be a real general pattern to which many cases would fit, it is impossible to say without a particular historical analysis of the taxon being discussed whether its presence in the New World is due to that generalized Gondwanan vicariant event or to a later transoceanic dispersal (i.e., dating the origin of the Scarabaeinae clade is not the same as dating the origin of its subordinate lineages, and a biogeographical generalization for the whole subfamily may not hold true for a younger ramification of it; indeed, Cambefort (1991: 54) makes a similar point when he writes "[...] although dung beetles may date back to the late Mesozoic [...], their present status and biogeography mostly reflect events that took place during Miocene, Pliocene, and Pleistocene"). As discussed by Sole \& Scholtz (2010), several instances of successful long-distance dispersals are known among the Scarabaeinae, and while Tarasov \& Génier's observation that the dung beetles' relatively poor flight capability would prevent them from crossing long ocean distances may hold some truth, it is important to bear in mind that an alternative way of crossing oceans is through rafting (as indeed recognized by Gunter et al. (2016) in relation to the Malagasy fauna). Therefore, the possibility of the existence of a considerable interconnection between the dung beetle fauna of the southern continents via long-distance dispersal must not be ruled out, and it is much more preferable that each case be analysed individually. This is particularly important for some of the most contentious cases of phylogenetic relationships between New World and Old World dung beetles do not refer to ancient ramifications in the Scarabaeinae tree of life, but rather to much more recent speciation events, including the relationship between species within the same lineage that more certainly do not date back to the Mesozoic (like some of the Oniticellini examples discussed above).

The present study, thereby, is intended to continue that effort to understand the diversity of the isolated elements in the Neotropical Scarabaeinae fauna and their biogeographical origin by investigating one of the rarest and most elusive genera in the region, Streblopus Van Lansberge, 1874. The taxonomic history of this group is quite interesting to discuss. The first mention of the taxon found in the literature is in Harold's landmark revision of the genus Canthon Hoffmannsegg, 1817 (Harold 1868). While concluding a paragraph dealing with the relationships between Canthon and some Old World groups such as Anachalcos Hope, 1837 (=Chalconotus Dejean, 1833) and Epilissus Dejean, 1836, Harold mentioned that a specimen bearing Klug's then yet-unpublished name Colonychus in the Berlin museum would be a link between the African "Epirhinen" and Canthon and discussed the characteristics that differentiate the two genera. As shall be discussed, by providing a list of characters distinguishing Colonychus from Canthon, Harold (1868) made Colonychus an available name, even though no species were assigned to the genus. Despite its availability, with just one exception (Kolbe 1905, 1907), no authors have used this name again as valid.

A few years later, Van Lansberge (1874a) proposed the new genus and species Streblopus opatroides based on an unknown number of both male and female specimens from the then-Brazilian province (now state) of Bahia, and mentioned that the new genus was possibly the same as the one mentioned by Harold (1868) as "Colonychus Klug". He considered S. opatroides to be "excessively ambiguous", because, according to him, while the species would be close to Deltochilum Eschscholtz, 1822, it also 
showed tarsi and a mesoventrite ("mesosternum") typical of the "Minthophilides" [sic], the pygidium of Byrrhidium Harold, 1869 and Coproecus Reiche, 1841, elytra and posterior legs as in Mentophilus Castelnau, 1840, and the base of the pronotum and the anterior legs of Onitis Fabricius, 1798. In sum, his new species showed a mosaic of characteristics that rendered its classification among the known dung beetle groups rather complicated, and Van Lansberge (1874a) only guessed that it was possibly close to Mentophilus and Byrrhidium. Later in that year, Van Lansberge (1874b) further elaborated his classification and considered Streblopus as part of the "Epirides" along with Mentophilus, Coproecus, Epirinus Dejean, 1833 and Labroma Sharp, 1873, whereas Byrrhidium would be part of the "Epilissides"; together, "Epirides" and "Epilissides" constituted the "Menthophilides", which was the second section of the tribe "Canthonides" along with the "true Canthonides" ("Canthonides vrais"), where Deltochilum and Canthon were classified.

With the exception of Gillet's and Lucas' catalogues (Gillet 1911; Lucas 1920), nothing would be written again on Streblopus until the late 1930s. In his study of the New World Canthonini (= Deltochilini), Paulian $(1938,1939)$ redescribed S. opatroides in fine detail and added the Brazilian state of Espírito Santo, just south of Bahia, to the known distribution range of the species, as well as Oxapampa, in the Pasco Region of Peru, on the other side of South America. Like Van Lansberge (1874a, 1874b) before him, Paulian (1939) considered Streblopus a mysterious genus as to its relationships, remarking that while its elytral striae and mesotibiae would indicate a proximity to the "Pinotides" (= Dichotomiini), its thorax to "Onitides" (= Onitini), and its metaventrite (= "metasternum") to Australian "Minthophilides", the shape of the posterior legs would make it a Canthonini.

Almost simultaneously with Paulian's work, Balthasar (1938) described the new genus and species Streblopoides punctatus based on a single specimen of unstated sex from Huancabamba (mispelled as "Huancamba"), in the Peruvian region of Piura, and related the new taxon to Streblopus due to their "Deltochilum-like" general appearance. However, according to him, both genera were different in the shape of maxillary palpi, the absence in Streblopoides of pronotal basal foveae, and by the shape of pygidium, mesocoxae and epipleura. It is clear, nonetheless, that Balthasar did not have access to specimens of $S$. opatroides during the preparation of his work and based his entire discussion on Van Lansberge's (1874a) rather brief and vague original description of the species, as he mentioned that he could not know whether the antennae of both species were similar since Van Lansberge did not describe the number of antennomeres in S. opatroides. As we shall discuss, the single individual of the latter species that Balthasar certainly had access to during his lifetime was a male from his personal collection mislabelled as having being collected in Honda, Colombia, and which now bears a label with Balthasar's handwriting identifying it tentatively as Streblopoides punctatus. Since Balthasar did not mention any specimens from Colombia in his 1938 work, it is clear that he acquired that specimen only after the description of $S$. punctatus and, even so, he could not correctly identify it as a $S$. opatroides. Not having compared both Streblopoides to Streblopus first hand, Balthasar's proposal of a new genus had a rather weak basis.

Indeed, this was noted as early as in the 1950s, when Pereira \& Martínez (1956), in their review of the then New World Canthonini (= Deltochilini), remarked that, judging from Balthasar's description, they could not find any justification for considering Streblopoides and Streblopus as two different genera. Nevertheless, since they had not seen specimens of the first taxon in person, they did not propose a formal synonymy between those names. That would change 10 years later, when Halffter \& Martínez (1966), after examining one of the male syntypes of Streblopus opatroides and a Peruvian female of Streblopoides punctatus collected in 1949, concluded that the two species differed little from one another and that no "fundamental character" (their words) would position them in different genera. They proposed, therefore, a formal synonymy between Streblopus and Streblopoides, with the first name being valid. However, Halffter \& Martínez (1966) went even further and speculated on whether both 
CUPELLO M. et al., Systematics of Streblopus and dung beetle biogeography

species names could represent, in fact, just a single species, as only a handful of specimens were known to them - only three males identified as $S$. opatroides and two females (including Balthasar's holotype) as $S$. punctatus - and the characters used to differentiate them could potentially turn out to be sexual secondary characters within a single species. Even so, given the disjunct distribution range of both putative species, one distributed in the Brazilian Atlantic Forest and the other in Peru (Paulian's record of S. opatroides from Peru was deemed incorrect), Halffter \& Martínez (1966) took a more conservative approach and considered both species valid. They stressed, however, that only with the discovery of females in the Atlantic Forest and males in Peru could their decision be confirmed.

Since then, very little has been reported specifically about Streblopus in the literature apart from CarvajalLópez et al.'s new record of S. punctatus from Ecuador (Carvajal-López et al. 2011) and the inclusion of $S$. opatroides in Tarasov \& Génier's phylogenetic study of Scarabaeinae (Tarasov \& Génier 2015). Outside the literature, however, our knowledge on the genus has greatly increased over the past two decades, during which a considerable volume of new specimens of both sexes was collected in Brazil, Peru and Ecuador and provided answers to the questions first posed by Halffter \& Martínez (1966) about the delimitations of $S$. punctatus and S. opatroides. Moreover, the increasing number of publications addressing the higher-level phylogeny of the Scarabaeinae has shown that much of what was written during the $20^{\text {th }}$ century about the subfamily's tribal-level classification and phylogeny was mistaken, and a new general picture of dung beetle evolutionary history has arisen. In this paper, we present new data on the morphology and distribution of Streblopus based on the examination of these recently collected series of specimens and put forward new hypotheses on the evolution and biogeography of the genus forged in the light of the aforementioned new discoveries about the high-level phylogeny of the Scarabaeinae.

In particular, we discuss the biogeographical implications of Tarasov \& Génier's finding that Streblopus is closely related to some Old World dung beetle lineages (Tarasov \& Génier 2015). We will contend that should this proposal be correct, then the presence of Streblopus in South America is best explained by a dispersal event that occurred sometime during the Upper Cretaceous or early Cenozoic through rafting across the Atlantic Ocean in the same way as hypothesized for several other organisms, both animals and plants. We hope this discussion will stimulate researchers to study the evolution of dung beetles (and other insects) from a historical narrative perspective, not just as a search for general patterns of distribution.

\section{Material and methods}

For the preparation of this paper, the following 33 collections were searched for specimens of Streblopus (curators or contact persons in parentheses):

\footnotetext{
$\mathrm{BMNH}=$ The Natural History Museum, London, United Kingdom (Max Barclay)

$\mathrm{CEAH}=$ Coleção Entomológica Adolph Hempel, Instituto Biológico, São Paulo, Brazil (Sergio Ide)

CEIOC = Coleção Entomológica do Instituto Oswaldo Cruz, Rio de Janeiro, Brazil (Jane Costa)

CEMT = Seção de Entomologia da Coleção Zoológica da Universidade Federal de Mato Grosso, Cuiabá, Brazil (Fernando Z. Vaz-de-Mello)

$\mathrm{CMNC}=$ Canadian Museum of Nature, Ottawa, Canada (François Génier)

CNCI = Canadian National Collection of Insects, Arachnids and Nematodes, Ottawa, Canada (Patrice Bouchard and Serge Laplante)

DZUP = Coleção Entomológica Padre Jesus Santiago Moure, Departamento de Zoologia, Universidade Federal do Paraná, Curitiba, Brazil (Lucia Massutti de Almeida)

FSCA = Florida State Collection of Arthropods, Gainesville, Florida, United States (Paul Skelley)

INPA = Instituto Nacional de Pesquisas da Amazônia, Manaus, Brazil (Marcio Luiz de Oliveira)
} 


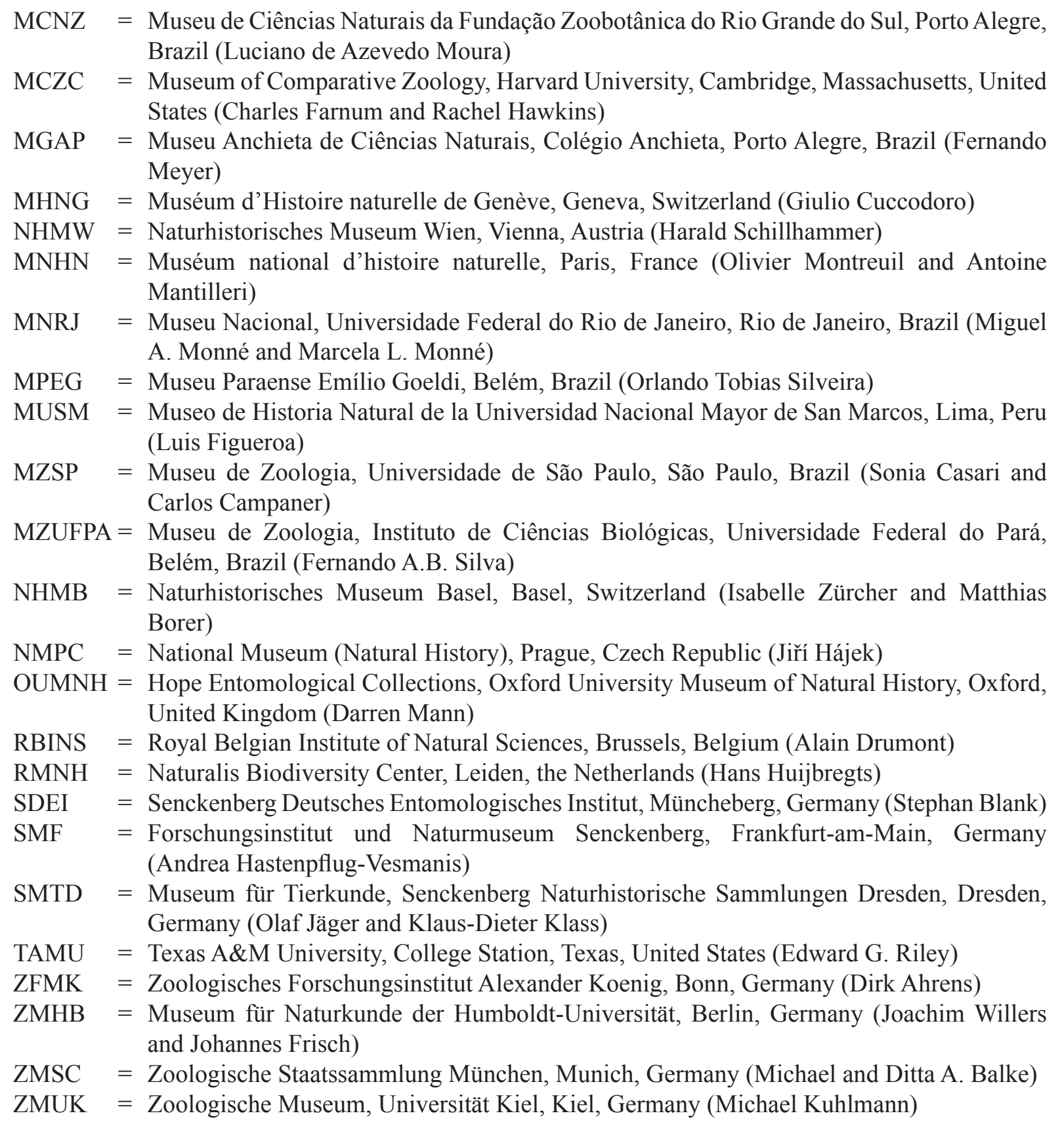

Of these, only nine originally held specimens of Streblopus: BMNH, CEMT, CMNC, MNHN, MNRJ, MUSM, MZSP, NMPC and RBINS. The only MNRJ specimen, however, a male S. opatroides prepared by the first author after several decades of storage in an envelope, was destroyed along with the rest of the institution's 5-million-specimen entomological collection in the great fire that consumed the main building of the museum on the evening of the $2^{\text {nd }}$ of September, 2018. On the other hand, we know from the literature that at least two additional institutional collections house specimens of Streblopus, namely the Instituto de Ciencias Biológicas, Escuela Politécnica Nacional (Quito, Ecuador), and the Museo de Zoología de la Universidad Técnica Particular de Loja (Loja, Ecuador) (Carvajal-López 2012; Chamorro et al. 2019). Apart from these, we are aware of no specimens of Streblopus deposited in any other museum. 
The morphological terminology adopted here follows standard references in dung beetle systematics such as Edmonds (1972), but as in a previous publication (Cupello \& Vaz-de-Mello 2018), we adopt the terminology employed by Beutel \& Lawrence (2005) and Lawrence et al. (2010) for the ventral and pleural sclerites of the beetle body (i.e., what is traditionally referred to as propleura, mesosternum, metasternum, mesepisternon and metepisternon in the taxonomic literature on Scarabaeinae is here called hypomeron, mesoventrite, metaventrite, mesanepisternon and metanepisternon, respectively). For the male genitalia, we mostly follow the terminology of Tarasov \& Génier (2015) except for our use of the term raspule (sensu Zunino 1972; Medina et al. 2013), which was referred to as "bristle" by Tarasov \& Génier (2015). Finally, the spermatheca terminology follows López-Guerrero \& Halffter (2000); that of the labrum follows Edmonds (1972), but Dellacasa et al. (2010) and Halffter (1961) were also consulted; the terminology for the genital sclerite is based on Medina et al. (2013); wing venation follows Kukalovà-Peck \& Lawrence $(1993,2004)$ aided by the interpretation of those two papers by Tarasov \& Génier (2015); see also Cupello \& Vaz-de-Mello (2018) for the terminology of the microsculpture of the tegument.

Using an ocular micrometer, specimens were measured as follows: total length (TL), greatest width of elytra (EW) and greatest width of pronotum (PW). For each variable, we specify, in millimetres, the average $(\mathrm{AV})$ and range with maximum $(\mathrm{MX})$ and minimum $(\mathrm{MN})$ values.

For each species, the geographical distribution is described in three different ways. The first is a general description of the species' distribution, citing relevant biomes where they occur. The second is according to the division of the globe in ecoregions as proposed by Olson et al. (2001) (an interactive map with information about these ecoregions is available online at WWF 2006). Finally, the third way is based on the political division of each country. In this latter case, countries and first order subdivision (e.g., states, provinces or departments) are presented in a geographical order (i.e., in a sequence 'north-south' and 'west-east'), while lower divisions are given in alphabetical order. Information on geographical distribution is mainly based on specimen labels. Information found in the literature - which is often less reliable than specimen label data - is also included; in those cases, the locality is written in italics in the 'Distribution' section for that species.

Species taxa are here interpreted according to the Biological Species Concept (Mayr 1940, 1942, 1963, 1970, 1996, and elsewhere; see also Cupello \& Vaz-de-Mello 2018 for a full discussion on this topic). We adopt, therefore, a realistic stance on the nature of the species category; in short, species are reproductive communities bonded together by means of interbreeding and isolated from other such reproductive communities as a consequence of reproductive isolation maintained by isolation mechanisms (see the aforementioned Mayr papers for a list of such mechanisms). The different supraspecific categories, however, are not real in that they do not reflect any particular real biological property of the taxa they rank specific to any of those categories (like being a reproductive community is an exclusive property of the species category); therefore, we have no yardstick to assign any particular supraspecific taxon to either the generic, the subgeneric or the tribal category, for instance. The supraspecific taxa, on the other hand, are real as far as they represent real supraspecific evolutionary individuals, namely clades. Here, therefore, any clade that has at least one shared biological property (in this paper, basically a morphological one, since nothing is known about the behaviour, genetics or any other biological aspects of Streblopus) that we consider will benefit from being highlighted and that, in this way, will facilitate communication among biologists (e.g., by facilitating ready identification) will be named and categorized (i.e., it will be treated as a taxon in the Linnean hierarchy). This clarification is important for our discussion on the synonymy between Streblopus and Streblopoides as proposed by Halffter \& Martínez (1966); otherwise, the reader would not know on what grounds our decision was based. 


\title{
Results
}

\author{
Phylum Arthropoda von Siebold, 1848 \\ Subphylum Hexapoda Blainville, 1816 \\ Class Insecta Linnaeus, 1758 \\ Order Coleoptera Linnaeus, 1758 \\ Suborder Polyphaga Emery, 1886 \\ Superfamily Scarabaeoidea Latreille, 1802 \\ Family Scarabaeidae Latreille, 1802 \\ Subfamily Scarabaeinae Latreille, 1802 \\ Genus Streblopus Van Lansberge, 1874
}

Colonychus Harold, 1868: 10.

Streblopus Van Lansberge, 1874a: 9-10.

Streblopoides Balthasar, 1938: 215-216.

Colonychus - Van Lansberge 1874a: 10 (as possible synonym of Streblopus). — Kolbe 1905: 552; 1907: 27. - Gillet 1911: 42 (as synonym of Streblopus). — Lucas 1920: 197 (as synonym of Streblopus). Paulian 1939:26 (as synonym of Streblopus). - Blackwelder 1944:203 (as synonym of Streblopus). Pereira \& Martínez 1956: 99 (as a supposed preoccupied synonym of Streblopus). - Halffter 1961: 226, 229 (as synonym of Streblopus). - Vulcano \& Pereira 1964: 580 (as a supposed nomen nudum referring to Streblopus). - Halffter \& Martínez 1966: 152 (as a supposed nomen nudum referring to Streblopus). — Krajcik 2006: 163 (as synonym of Streblopus). — Chamorro et al. 2019: 234 (as a supposed nomen nudum referring to Streblopus). — Cupello \& Vaz-de-Mello 2019: 168-171 (as synonym of Streblopus).

Streblopus-VanLansberge 1874b:187,189._Karsch 1887:1.—Ritsema 1888:209.—Gillet 1911:42._ Lucas 1920: 617._Olsoufieff 1935:34._Paulian 1938:234; 1939:26._Balthasar 1941:345; 1951: 330. — Blackwelder 1944: 203. — Pereira \& Martínez 1956: 94, 99, 182. — Halffter 1961: 229-230, 253; 1974: 257; 2003: 22. — Vulcano \& Pereira 1964: 580; 1967: 548-549. — Halffter \& Matthews 1966: 260. — Halffter \& Martínez 1966: 103, 152-163, figs 13-21; 1967: 79; 1968: 210; 1977: 34, 43. — Matthews 1971: 49. — Martínez \& Halffter 1972: 33. — Halffter \& Edmonds 1982: 201. — Hanski \& Cambefort 1991: 472. — Vaz-de-Mello 2000: 195. — Medina \& Scholtz 2005: 154. Krajcik 2006: 163; 2012: 249. - Scholtz et al. 2009: 566. - Carvajal-López et al. 2011: 122, 316. — Vaz-de-Mello et al. 2011: 6, 11, 18, 25, 33, 40, 45. - Carvajal-López 2012: 195. — Chamorro et al. 2018: 98; 2019: 10, 234. - Cupello \& Vaz-de-Mello 2019: 168-171.

Streblopoides - Balthasar 1941:346; 1951: 331. — Blackwelder 1944: 203. — Pereira \& Martínez 1956: 99. — Halffter 1961: 229; 1974: 257 (as synonym of Streblopus). — Vulcano \& Pereira 1964: 580. — Halffter \& Matthews 1966: 260. - Halffter \& Martínez 1966: 103, 153-154, 158 (as synonym of Streblopus); 1967: 79 (as synonym of Streblopus); 1977: 34, 43 (as synonym of Streblopus). Krajcik 2006: 163 (as of dubious validity). - Chamorro et al. 2019: 234 (as synonym of Streblopus). — Cupello \& Vaz-de-Mello 2019: 168-169 (as synonym of Streblopus).

\section{Type species}

Colonychus: Never fixed (see discussion below). - Streblopus: Streblopus opatroides Van Lansberge, 1874, by original monotypy (Van Lansberge 1874a: 9-10). - Streblopoides: Streblopoides punctatus Balthasar, 1938, by original monotypy (Balthasar 1938: 215-216).

\section{Etymology}

Colonychus: Dubious. Possibly from the Latin prefix 'col-', meaning 'with', and the Greek word 'onychus', meaning 'claw' (Brown 1956). Masculine. - Streblopus: Dubious. Possibly derived from 
CUPELLO M. et al., Systematics of Streblopus and dung beetle biogeography

the Greek word 'Streblos' for 'twisted, crooked, wrinkled' (Brown 1956). Masculine. - Streblopoides: Derived from Streblopus in reference to the close relationship between Balthasar's new genus and Van Lansberge's.

\section{Differential diagnosis}

Streblopus is possibly the most readily differentiable genus of the New World dung beetle fauna. As all identification keys that included Streblopus have noted (Paulian 1938; Pereira \& Martínez 1956; Vulcano \& Pereira 1967; Halffter \& Martínez 1977; Vaz-de-Mello et al. 2011), the posteromedian dentiform process of the pronotum of both species is unique among the Scarabaeinae (Figs 1A-C, 3A, C-D, 12A-B) and can be confidently used to separate the genus from the other groups in the subfamily. The general aspect of the body, which is very elongate, flattened and shows neither cephalic nor pronotal horns, also adds to the peculiar appearance of the genus (Figs 1A-C, 3A, C-D), as well as the shape of its labial palpi, whose basal palpomere is unusually expanded (Fig. 11D). Indeed, Streblopus is so distinctive that it is difficult to point out any genera with which it could be confused. From the Deltochilini, apart from the characters listed above, Streblopus differs by its mesotibiae being abruptly expanded at the apex in males (Fig. 18A, C); from Deltochilum, in particular, a genus that was once said to be similar to Streblopus (Van Lansberge 1874a; Balthasar 1938) and with which it shares a wide pseudepipleura, Streblopus is different, among many other features, by the absence of tubercles at the apex of the elytra. Its slender metatibiae (Fig. 20A-D), in turn, will separate Streblopus from Dichotomiini and Coprini, while the presence of tarsal claws (among many other characters) differentiates the genus from the Eucraniini and the absence of three pairs of sharp clypeal teeth will separate it from Scarabaeini. Finally, Streblopus is different from the Eurysternini in not having a visible scutellum, its mesocoxae are obliquely positioned (Fig. 13C-F) and the labial palpi are 3-articulated (Fig. 11D), whereas Eurysternus, the only genus of its tribe, has a visible scutellum, parallel mesocoxae and 2-articulated labial palpi (see Génier 2009 for more details). Although certainly far from being exclusive to Streblopus, the labrum having the anterior margin deeply emarginated (Fig. 8A-D), the protarsi being absent in both sexes (Figs 15A-H, 16C), the metacoxae having a lateral spur covering the epipleura (Fig. 19A), the hind wing having a deep notch at the area of the anal fold (Fig. 21F), the asymmetrical parameres (Fig. 23A-H) and the reduced sclerites of the internal sac (Figs 24A-F, 25A-E) are also remarkable features of this genus.

\section{Redescription}

HEAD. Transverse, with apex ranging from clearly emarginated (males of $S$. opatroides) to truncate (females of S. punctatus); emargination, when present, flanked by two small teeth; remainder of outer edge simply rounded, with no accessory teeth or notch between clypeus and paraocular areas ('genae') (Fig. 5A-D). Suture between clypeus and paraocular areas present and well-marked, with a tenuous tumescence (more evident in males) on clypeus adjacent to suture (Fig. 5A-D); fronto-clypeal suture vestigial, present very shortly and only at laterals adjacent to eyes (Fig. 5A-D). Eyes with dorsal surface wide, largest width as wide as one-fifth to one-fourth of interocular space; with a short (S. punctatus) or pronounced (S. opatroides) canthus (Fig. 5E-F). Entire dorsal surface of head covered by small umbilicate punctation, progressively denser from apex of clypeus towards frons and paraocular area; dorsal surface almost entirely flat, without any traces of horns, tubercles or elevations; a very tenuous depression present only behind apical emargination of clypeus and in paraocular areas in front of eyes. Clypeal process transverse, with apex either rounded (Fig. 16A) or acuminate (Fig. 16B). Antennae 8- or 9-articulated (funicle with 3 or 4 articles) (Fig. 7A-B). Labrum with lateral projections well developed and with anterior labral margin deeply U-emarginated; epipharynx with well-developed median brush and well-delimited lateral files (Fig. 8A-D). Mandibles (Fig. 9A-C), maxillae (Fig. 10A-C) and labium (Fig. 11A-C) typical of dung beetles, without any notable variation, except for shape of 3-articulated labial palpi, with basal palpomere largely expanded and almost twice as long as second and third palpomeres combined (Fig. 11D). 
Thorax. Pronotum transverse, convex, with no elevations, grooves or depressions (Fig. 12A-B); lateral foveae tiny, but clearly impressed; posterior foveae absent; lateral and anterior edges marginate, anterior margin with a membranous area covering base of frons; lateral edges sinuous in both dorsal and lateral views; postero-lateral angles strongly projecting in an acuminate (or slightly rounded) projection; posterior edge highly sinuous, with a strong flange projecting backwards at centre covering base of elytral suture;
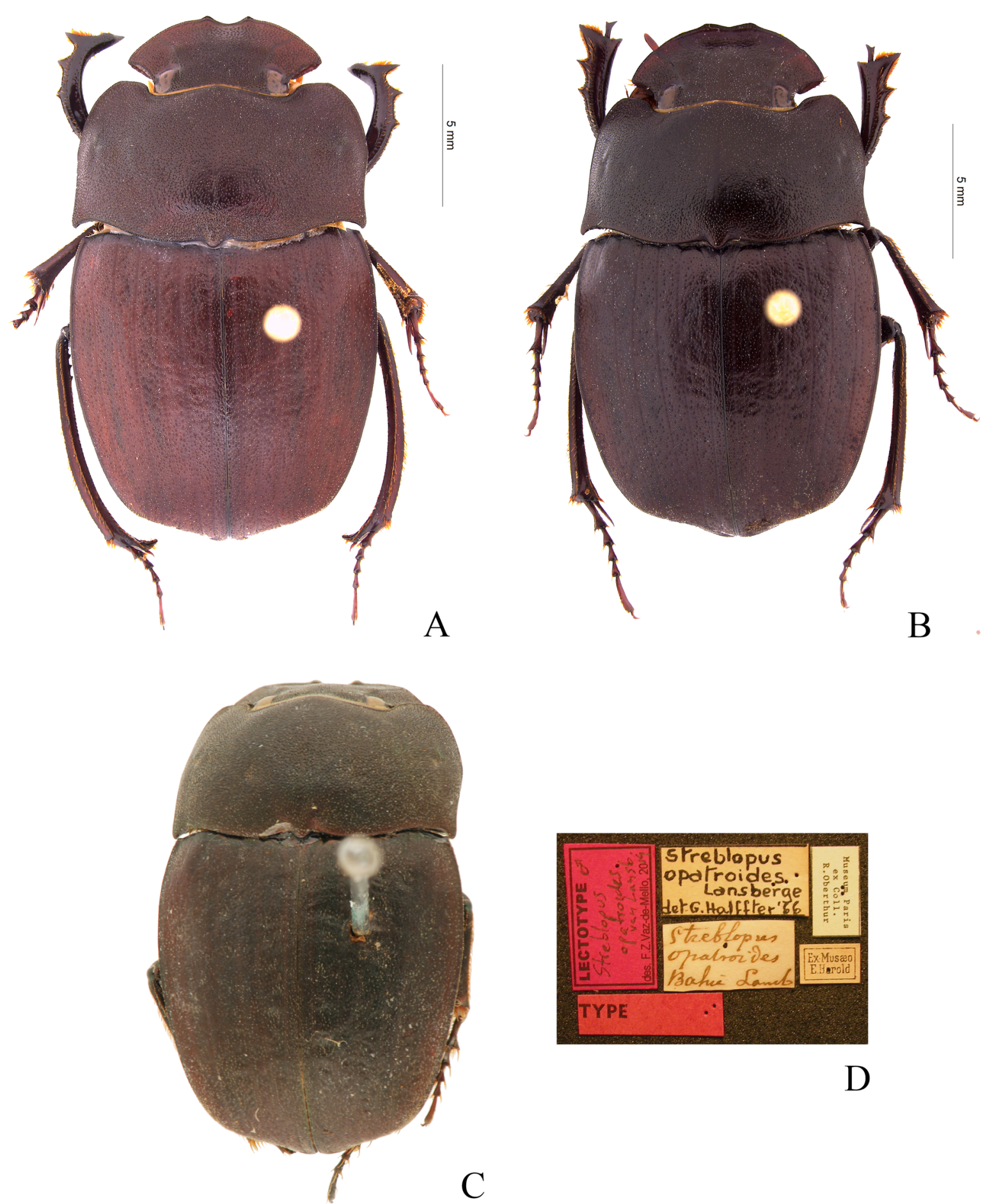

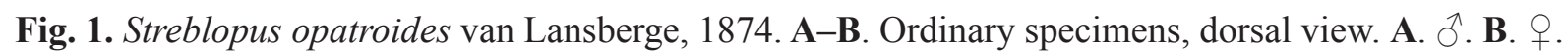

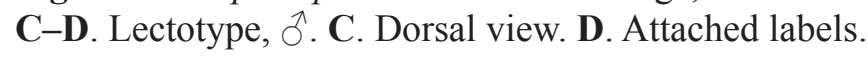


surface of pronotum covered by umbilicate punctation, varying in density between species. Hypomeron with anterior region covered by small umbilicate punctures similar to and bearing setae slightly longer than those of head and pronotum, and posterior region with punctures with setae much longer than on rest of tegument (Fig. 13A); hypomeral carina completely absent; anterior region of hypomeron not excavated, posterior region declivous (Fig. 13A). Prosternum, mesoventrite, mesanepisterna and metanepisterna entirely covered by umbilicate punctation, varying in density between species (Fig. 13B-F); tegument between punctures smooth or with a very diffuse rivulose microsculpture. Mesoventrite wide, with a broad transverse groove at centre (Fig. 13B). Meso-metaventral suture arched (Fig. 13B). Metaventrite covered by umbilicate punctation, denser towards anterior lobe and sides; centre almost devoid of any punctation; posterior region clearly depressed, varying in degree between sexes (Fig. 13C-F).

LEGS. With a highly marked sexual dimorphism and intrasexual allometric variation. All femora and tibiae with ventral surface covered by umbilicate punctation (Figs 14A-B, 17A-F, 18A-D, 19B-E, 20A-D). Protarsi lacking in both sexes. Protibiae with three acute teeth on apical half of exterior edge; basal half marked by a row of smaller denticles (Fig. 15A-H). Mesocoxae obliquely orientated to one another, with surface covered by umbilicate punctation, ranging in density between species (Fig. 13C-F). Meso- and metafemora linear and lacking both anterior and posterior margins (Figs 17A-F, 19B-E). Mesotibiae slender, but abruptly expanded near apex (Fig. 18A-D). Mesotarsi long and slender, at least as long as mesotibiae; basal and apical mesotarsomeres subequal in length and as long as mesotarsomeres II-IV combined. Metacoxae with external spur covering epipleura (Fig. 19A, red arrow). Metatrochanters with a sexually-dimorphic brush of long setae at posterior edge (Fig. 19B-E). Metatibiae slender, longer than metafemora (Fig. 20A-D). Metatarsi long, at least as long as half-length of metatibiae; metatarsomeres I-IV more or less equivalent in length (tarsomeres slightly shorter towards apex); metatarsomere V very long, almost as long as combined length of metatarsomeres II-IV. Meso- and metatarsal claws curved, well developed.

ELYTRA. With a broad pseudepipleura delimited by a short carina adjacent to stria VII; epipleura very narrow (Fig. 21A). With nine fine and well-delimited striae, seven on disc and two on pseudepipleura; striae interrupted by umbilicate punctures along their entire length. Striae I and IX, II and VIII, and III and IV or V connected to one another at apex of elytra; stria VIII absent at base of pseudepipleura. Elytral tegument with umbilicate punctation and with well-delimited alveolar microsculpture between umbilicate punctures. Elytral umbilicate punctures of subequal width or with variable width. Scutellary impression absent; scutellum not visible from above, entirely covered by base of elytra.

ABDOMEN. With six ventrites covered by umbilicate punctation. Ventrites I-IV with punctation more clearly marked at their anterior half; ventrite V evenly punctate; ventrite VI evenly punctate at sides and smooth or with punctures very sparse at centre. Abdomen very short at centre, with length subequal to separation between meso- and metacoxae. Ventrite VI as long as ventrites III-V combined. Pygidium very short and deflected towards venter, surface covered by umbilicate punctures; completely marginate, with basal margin slightly raised (Fig. 22C); prepygidium grooved at centre, surface lacking umbilicate punctation (Fig. 22C).

Terminalia. Aedeagus: Parameres largely asymmetrical, right paramere with clear apical projection (Fig. 23A-H); in dorsal view, with lateral edges straight or curved; in lateral view, ventral region straight or inclined towards apex, with either well-delimited or tenuous pair of ventral keels. Internal sac with only three sclerites: axial, subaxial and superior right peripheral sclerites (Figs 24A-F, 25A-E); superior right peripheral sclerite with well-delimited superior ring and broad, long inferior lobe ('cable') with triangular area more sclerotized near edge (Figs 24E, 25E); axial and subapical sclerites only loosely connected, easily separable. With well-developed raspule covered by tiny scales (Figs 24A-C, 25A-C).Genital segment: With well-developed medial sclerotized plate and lateral sclerotized plates 
(Fig. 26A-B). - Spermatheca: C-shaped, both externally and internally smooth, with or without pair of apical hooks (Fig. 27A-C).

SEXUAL DIMORPHISM. Male: Metaventrite strongly excavated posteriorly; concavity marked anteriorly by strong spur (Fig. 13C, E). Profemora robust, strongly enlarged at centre (Fig. 14A, C); with anterior margin raised at centre into one or two strong spurs (Fig. 14A, C); trochantofemoral articulation with raised edge forming a short spine or not. Protibiae robust, curved inwards and downwards, with ventral carina

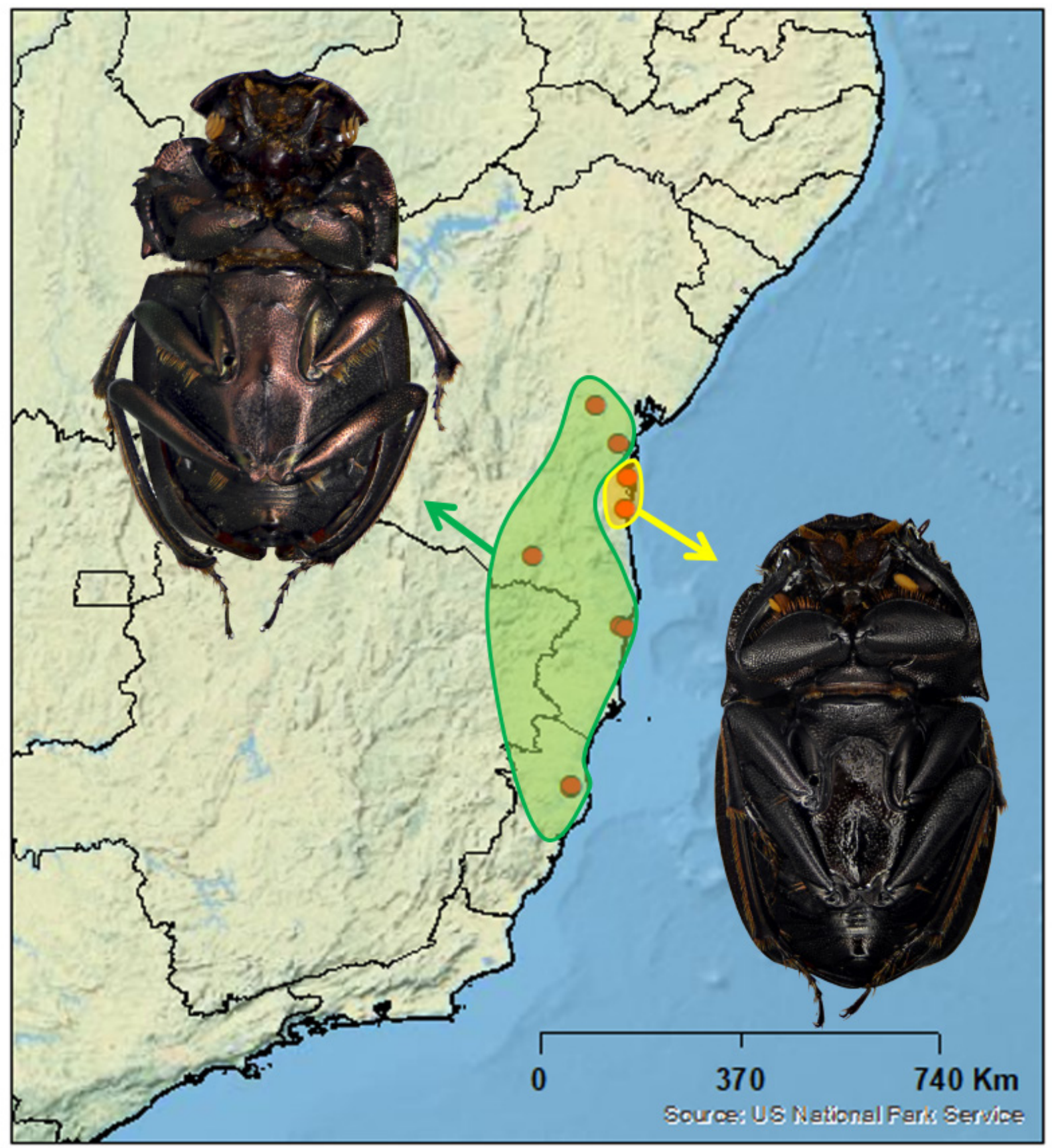

Fig. 2. Geographical variation in Streblopus opatroides van Lansberge, 1874. Individuals from a few localities in southeast Bahia (Maraú and Uruçuca) have a different ventral colouration from individuals belonging to other populations, being much darker and not showing the typical red metallic colouration seen in specimens from other localities in Bahia and Espírito Santo. 
CUPELLO M. et al., Systematics of Streblopus and dung beetle biogeography

interrupted by a longitudinal row of strong teeth; when fully closed, protibiae completely cover anterior edge of profemora; protibial spur present or not (Figs 15A, C, E, G, 16C); apical region of protibiae truncate and expanded inwards into long spur, with two transverse rows of setae (one covering anterior edge of apical lateral teeth, the other covering long spur) (Fig. 16C). Mesotibiae with internal angle of apical edge strongly projecting (Fig. 18A, C). Metatrochanter with wide brush of long setae, covering almost entire posterior edge (Fig. 19B, D). Metatibiae with apical edge strongly projecting inwards (Figs 19E, 20C, E); metatibial spur very short, rudimentary, much shorter than basal metatarsomere (Fig. 20E). Abdomen, in lateral view, contracted, concave (Fig. 22A). - Female: Metaventrite only shallowly excavated posteriorly, without indentation marking anterior margin of concavity (Fig. 13D, F). Profemora more linear, anterior margin simple, not raised (Fig. 14B, D); trochantofemoral articulation not developed into spur. Protibiae gracile, only slightly bent inward, not bent downwards (Fig. 15B, D, F, H); internal angle of apex projected into short spur (Fig. 15B, D, F, H); ventral carina simple, not interrupted by row of teeth; at apex, ventral carina marked by tuft of long setae. Mesotibiae with apical expansion, a result of a slight expansion of both internal and external edges, not only internal one (Fig. 18B, D). Metatrochanter with thin brush of long setae on posterior edge (Fig. 19C, E). Metatibiae with apex not expanded inwards, but with sharp spine at internal angle (Fig. 20D, F); metatibial spur well developed, very long, longer than basal metatarsomere (Fig. 20F). Abdomen, in lateral view, flat (Fig. 22B).

\section{Distribution}

As discussed in detail below, the distribution of Streblopus is clearly relict. While one species, S. punctatus, is known from some few sub-Andean localities in eastern Amazonia in Peru and Ecuador, the other, $S$. opatroides, is known from a larger number of places, but which cover a more limited range in the Atlantic Forest along the Brazilian states of Bahia and Espírito Santo. The genus, therefore, is present in - and limited to - the two major tropical forest ecosystems of South America east of the Andes, and its two species are separated by more than $2000 \mathrm{~km}$ of open and drier landscapes composing the Cerrado, in the central area of the South American Dry Diagonal (Fig. 4).

\section{Ecology}

Almost nothing is known about the biology of Streblopus. The specimens gathered over the past years at CEMT and CMNC were mostly collected using pitfall traps baited with human faeces; no specimens are known to have been collected using other types of bait (except literature records for pig dung) or traps. Judging from its morphology, especially the shape of its metatibiae, which are slender and long in both species, we assume the genus should be a roller (something Halffter \& Martínez (1966: 157) had already hypothesized) and possibly belongs to the functional Pattern IV of Halffter \& Edmonds' classification of dung beetle nesting behaviour (Halffter \& Edmonds 1982). Also based on the morphology, the genus is almost certainly nocturnal, as indicated by the large size of the dorsal surface of its eyes (Raine et al. 2019; Tocco et al. 2019) and the dark dorsal colouration, without any or with only few traces of metallic sheen (Hernández 2002; Feer \& Pincebourde 2005).

\section{Remarks}

As discussed in the Introduction, the first name by which the genus was referred to in the literature was Colonychus by Harold (1868). Although it was only six years later that Van Lansberge (1874) established the name Streblopus, almost all authors except Kolbe $(1905,1907)$ have been using Van Lansberge's name instead of Colonychus, mostly treating the latter as either a nomen nudum (Vulcano \& Pereira 1964; Halffter \& Martínez 1966) or an available preoccupied name (Pereira \& Martínez 1956). However, since Harold (1868) did not intend to establish a new nominal genus nor included a nominal species in it, one is led to ask whether Colonychus is available or not and, if so, whether it is indeed a synonym of Streblopus. If both questions have a positive answer, then the validity of Streblopus would 

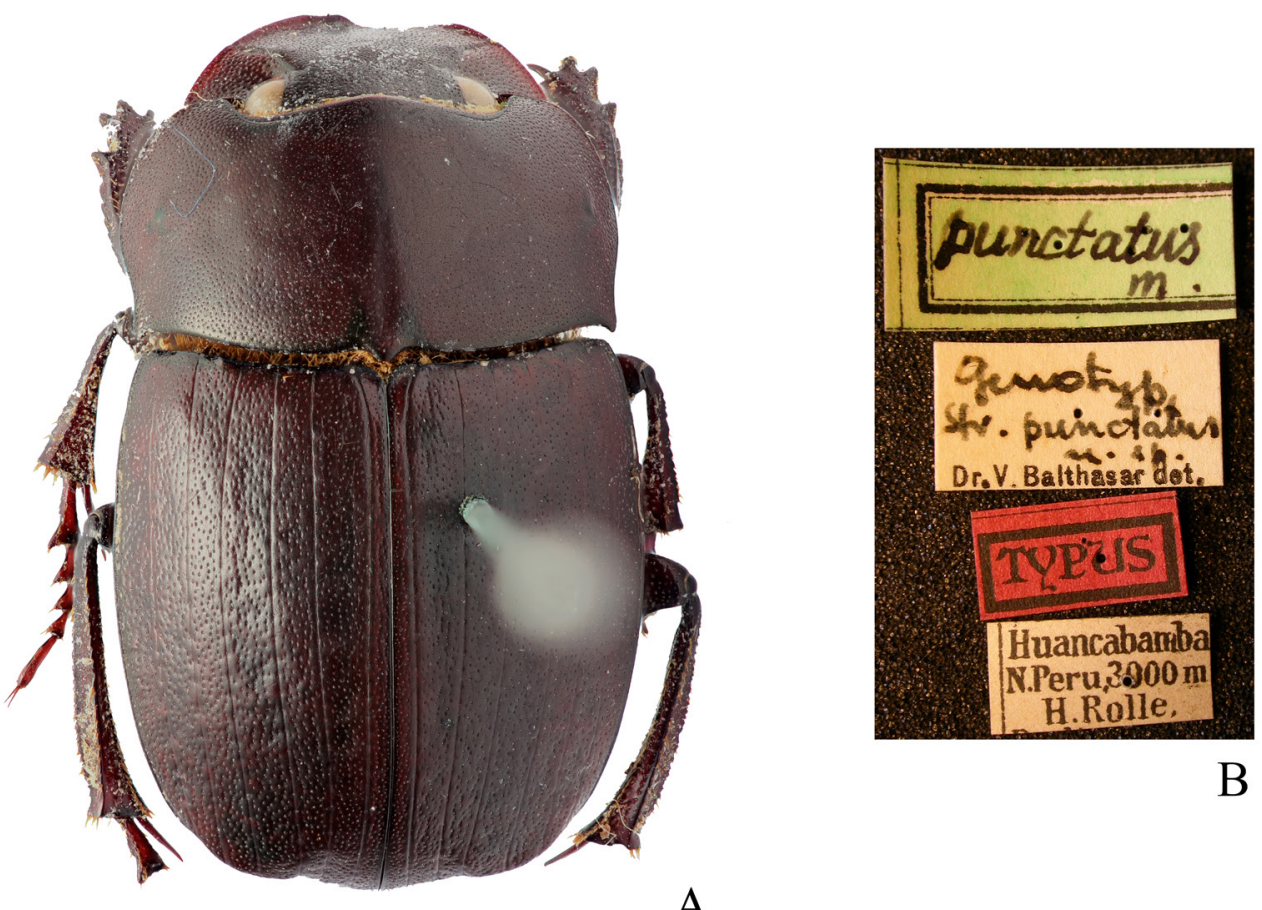

B

A
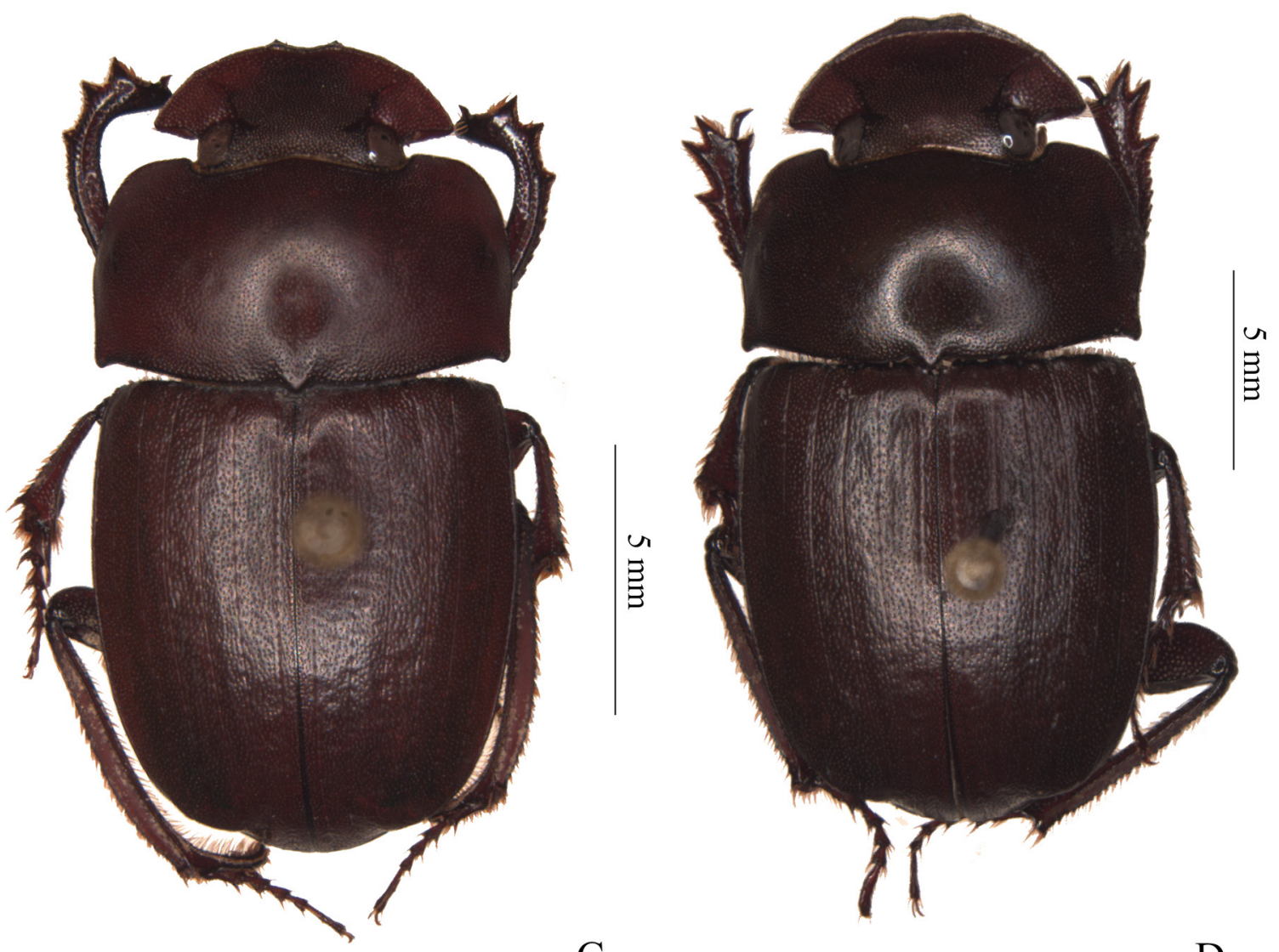

$\mathrm{C}$

Fig. 3. Streblopus punctatus (Balthasar, 1938). A-B. Holotype, $q$. A. Dorsal view. B. Attached labels. C-D. Ordinary specimens, dorsal view. C. $\overbrace{}^{\top}$. D. $q$. 
CUPELLO M. et al., Systematics of Streblopus and dung beetle biogeography

be threatened in favour of Colonychus, something that would disturb a nomenclatural stability that has reigned for almost 150 years.

As for the availability of Colonychus, Harold (1868: 10) cited the name in his discussion on the affinities of some Old World genera of Scarabaeinae with the New World genus Canthon, the group he was revising in that paper. There, Harold mentioned that a specimen bearing Klug's then-unpublished name Colonychus in the Berlin museum could be a link between the African "Epirhinen" and Canthon, and discussed the characteristics that differentiate the two genera, stating the following:

"In between these ['Epirhinen'] and Canthon, there may be, however, placed a yet undescribed genus, which was indicated as Colonychus by Klug at the Berlin museum, and which is characterized by absent protarsi, elytra surpassing the abdomen, very slightly laterally compressed metatarsi and angularly inwards-dilated apices of the tibiae"; in the original German: "Zwischen diesen ['Epirhinen'] und Canthon dürfte aber eine noch unbeschriebene, im Berliner Museum von Klug als Colonychus verzeichnete brasilianische Gattung sich einreihen, die durch fehlende Vordertarsen, den Hinterleib überragende Flügeldecken, seitlich nur sehr wenig flachgedrückte Hinterfüsse und am Ende nach innen hackig erweiterte Schienen ausgezeichnet ist" (Harold 1868: 10).

Therefore, although Harold clearly did not intend to formally describe the new genus Colonychus (even attributing its authorship to the German entomologist Johann Christoph Friedrich Klug (1775-1856) and not citing the genus in his catalogue of the world Scarabaeinae the following year, Harold 1869), he expressly presented characters that both describe the genus and differentiate it from related groups. In doing so, Harold (1868) complied with all the availability criteria established by the Articles 10, 11 and 12 of the ICZN Code and, therefore, made Colonychus an available name (ICZN 1999). It is particularly important to stress here that the fact that Harold did not assign any nominal species to Colonychus does not interfere with our conclusion, since neither the inclusion of a nominal species nor the fixation of a type species are necessary conditions for a nominal genus published before 1931 to be available under the provisions of the current Code. The fact that Article 69.3 recognizes the possibility of a genus being established without any included species and introduces the concept of "subsequent monotypy" confirms this interpretation.

But while certainly available, is Colonychus a synonym of Streblopus as sustained by all authors who have cited the former name since the $19^{\text {th }}$ century? Since no type species has ever been fixed for Colonychus, it is impossible to answer this question objectively, but several facts indicate that this is indeed the case. Firstly, although rather schematic, Harold's description of Colonychus is consistent with the morphology of Streblopus, as is the geographical origin cited (Brazil). More importantly, Van Lansberge (1874a) himself recognized the possibility of Colonychus being a synonym of Streblopus in the original publication of the latter name (he cited "Colonychus Klug in litt." followed by a question mark after the description of his new genus), and this synonymy has been accepted by all authors ever since (Gillet 1911; Lucas 1920; Paulian 1939; Blackwelder 1944; Pereira \& Martínez 1956; Vulcano \& Pereira 1964; Halffter \& Martínez 1966; Krajcik 2006).

In June 2016, the first author visited the ZMHB and looked without success for the Klug specimen cited by Harold (1868); in fact, no specimens of Streblopus were found either there or in any other German collection surveyed by us. Halffter \& Martínez (1966), however, having studied the Harold collection housed in the MNHN, found a male S. opatroides labelled "Colonychus / ex Musaeo E. Harold, ex Collection Oberthur" [sic]. This specimen was re-examined by the first author at the MNHN in September 2019 and we can confirm its species identity and the label information provided by Halffter \& Martínez (1966), transcribing the latter as follows (italics indicate handwritten data, slashes separate lines): 1 . "Colónyčhus", 2. "Ex-Musæo / E. Harold”, 3. "Museum Paris / ex Coll. / R.Oberthur", 4. "Streblopus / 
opatroides / Lansberge / det. G. Halffter '66". If not the Klug specimen cited by Harold (1868) and not found by MC in the ZMHB (and it does not seem to be, since the handwriting of the Colonychus label is not similar to Klug's), at least this male's identity as a member of Colonychus was not doubted by Harold. Indeed, it is possible that Harold himself was the author of this specimen's Colonychus label and that he based the identification on a comparison with the Klug specimen in Berlin. If correct, this indicates that Colonychus does refer to the same genus taxon as Streblopus and that both names are, therefore, subjective synonyms. It is important to note that Paulian (1939), who also studied material at

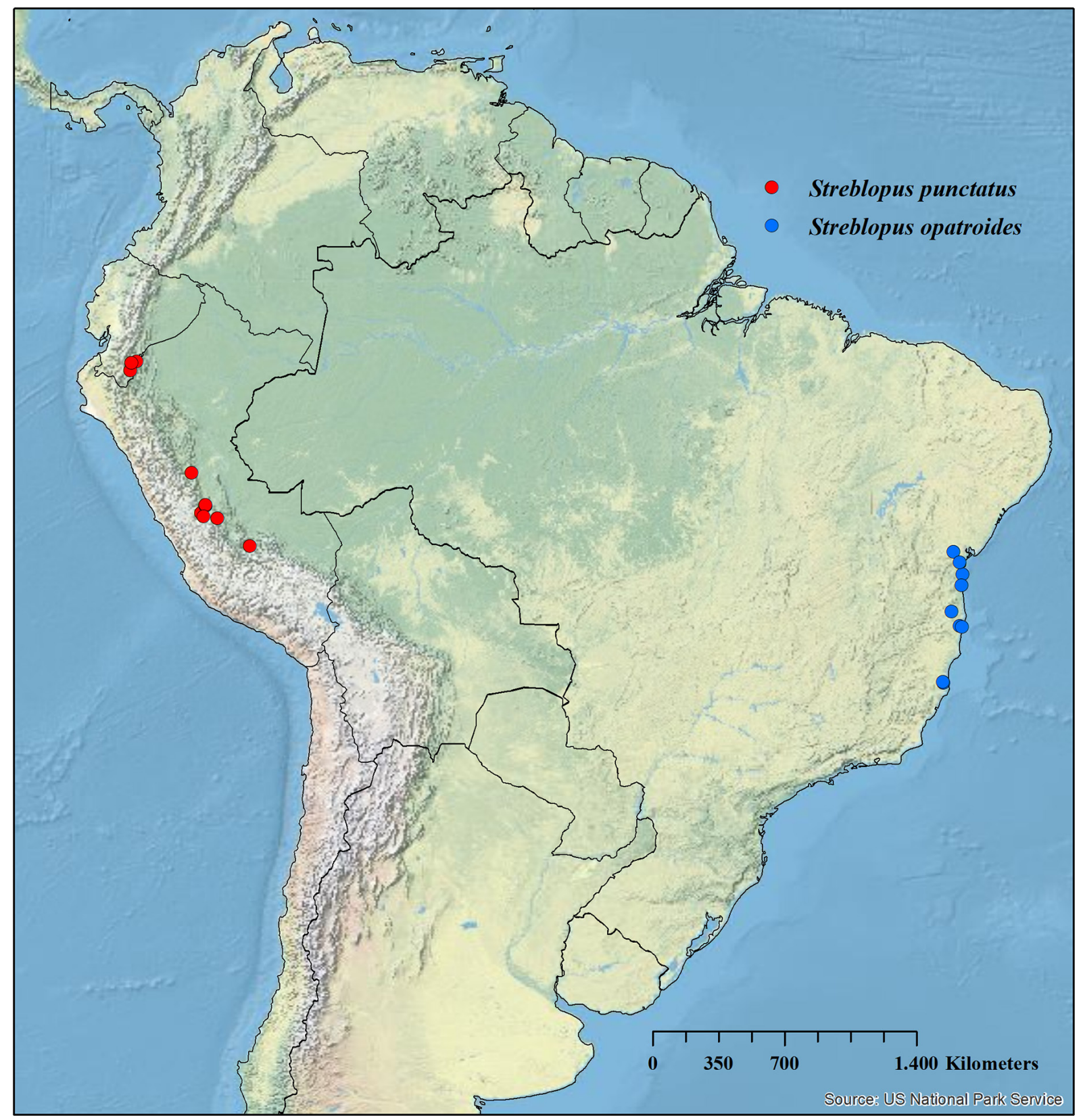

Fig. 4. Distribution of Streblopus van Lansberge, 1874. Note how the two species are widely separated by the vast South American Dry Diagonal stretching between Amazonia and the Atlantic Forest. During several different times over the Neogene, forest corridors connected the two biomes and the populations of Streblopus could move from one to the other. When the forest retreated, the distribution of the genus became relict. 
CUPELLO M. et al., Systematics of Streblopus and dung beetle biogeography

the MNHN, did not mention the "Colonychus specimen" examined by Halffter \& Martínez (1966) and found by us there, probably because Harold's collection only went to the MNHN in 1952, when the René Oberthür collection was incorporated into that museum (Horn et al. 1990b).

Being available and a senior synonym of Streblopus, Colonychus has nomenclatural priority over the former nominal genus and would have to be used as the valid name for the genus taxon that includes S. opatroides and S. punctatus. A final allegation against the use of Colonychus comes from Pereira \& Martínez (1956), who argued the name is preoccupied, but who did not state what senior homonym would that be. After searching both in the Nomenclator Zoologicus (Anonymous 2004) and on Google, we were unable to find any Colonychus other than Harold's. It seems, therefore, that Pereira \& Martínez's (1956) characterization of Colonychus as a junior homonym is incorrect.

In sum, Colonychus Harold, 1868 is an available name, a senior subjective synonym of Streblopus Van Lansberge, 1874 and, not being preoccupied, would have to be used as the valid name for the genus following the Principle of Priority. We are of the opinion, however, that using Colonychus as valid after a period of 150 years of an almost unanimous use of Streblopus as the valid name of the genus, and relegating the latter to invalidity, would not serve the Code's goal of nomenclatural stability and, therefore, should not be put in practice. In our opinion, reversal of priority, as established in the Code's Article 23.9, is the best way to preserve stability in this case. While complying with the conditions of Article 23.9.1.2, unfortunately this case does not comply with Article 23.9.1.1, since Kolbe (1905, 1907) cited Colonychus in passing as a valid genus in two rather brief discussions about the generic composition of Canthonini. Consequently, we are not free to use Articles 23.9.1 and 23.9.2 to consider Colonychus a nomen oblitum and, in this way, definitely preserve Streblopus as valid. We have decided, therefore, to invoke Articles 23.9.3 and 82.1.3 and referred this case to the International Commission on Zoological Nomenclature and asked for the conservation of Streblopus by suppressing Colonychus for the purposes of the Principle of Priority (Cupello \& Vaz-de-Mello 2019). Until the Commission rules on this case, the use of the junior synonym, Streblopus, should be maintained according to Article 23.9.3.

\section{Identification key to the species of Streblopus Van Lansberge, 1874}

1. Clypeus of males strongly emarginated at apex, emargination flanked by two tiny, but evident teeth (Fig. 5A); females with only tenuous emargination and teeth (Fig. 5B). Eye canthus long, reaching centre of eyes in lateral view (Fig. 5D). Clypeal process rounded at apex (Fig. 6A). Antennae 9-articulated (Fig. 7A). Pronotum entirely covered by dense umbilicate punctation (Fig. 12A). Metaventrite of males with broad concavity on posterior region (Fig. 13C). Protibiae of females with lateral teeth equally distant from one another and pointed more or less laterally (Fig. 15B, F). Protibial spur present only in females; spur straight and apically bifurcated (Fig. 15B, F). Mesofemora of males with brush of setae at basal half of posterior edge (Fig. 17A). Mesotibiae of males with short apical expansion (Fig. 18A); mesotibiae of females with apical edge deeply emarginated (Fig. 18B). Metafemora of males with long spur at posterior edge (Fig. 19B); both sexes glabrous on posterior edge (except for tuft of setae on surface of male posterior spur). Metatibiae of males with a longitudinal row of sharp teeth at base (Fig. 20A); females without such teeth (Fig. 20B). Elytra covered by dense umbilicate punctation and with distal calluses only slightly projected (Fig. 21D); epipleural carina entirely interrupted by umbilicate punctures (Fig. 21B) (Atlantic Forest in the Brazilian states of Bahia and Espírito Santo) .........Streblopus opatroides Van Lansberge, 1874

- Clypeus of males only tenuously emarginated at apex and flanked by two fairly tenuous teeth (Fig. 5C); females with apex of clypeus straight or only tenuously emarginated, teeth absent or only tenuously marked (Fig. 5D). Eye canthus short, not reaching centre of eyes in lateral view (Fig. 5E). Clypeal process triangular, acuminate at apex (Fig. 6B). Antennae 8-articulated (Fig. 7B). Pronotum with centre only sparsely covered by tiny umbilicate punctures (Fig. 12B); umbilicate punctures progressively denser towards sides. Metaventrite of males with a narrower concavity on posterior 
region (Fig. 13E). Protibiae of females with two most distal teeth closer to one another than to proximal teeth; all teeth pointed distinctly forwards (Fig. 15D, H); protibial spur present in both sexes; female spur curved apically, not bifurcated (Fig. 15D, H). Mesofemora of males with posterior edge entirely glabrous or with a few sparse setae (Fig. 17C, E). Mesotibiae of males with long apical expansion (Fig. 18C); metatibiae of females with rounded apical edge (Fig. 18D). Metafemora of males with a short spur near metatrochanter; both sexes with posterior edge with long setae, which form a welldefined brush in males (Fig. 19D-E). Metatibiae of both sexes without lateral teeth (Fig. 20C-D). Elytra covered by sparse umbilicate punctation and with distal calluses strongly projecting (Fig. 21E); epipleural carina smooth or with only some sparse and tiny punctures (Fig. 21C) (Sub-Andean areas in the Peruvian and Ecuadorian Amazon Forest) .........Streblopus punctatus (Balthasar, 1938)

Streblopus opatroides Van Lansberge, 1874

Figs 1-2, 4, 5A-B, E, 6A, C, 7A, 8A-B, 9-11, 12A, 13A-D, 14A-B, 15A-B, E-F, 16A, 17A-B, $18 \mathrm{~A}-\mathrm{B}, 19 \mathrm{~A}-\mathrm{C}, 20 \mathrm{~A}-\mathrm{B}, \mathrm{E}-\mathrm{F}, 21 \mathrm{~A}-\mathrm{B}, \mathrm{D}, \mathrm{F}, 22,23 \mathrm{~A}-\mathrm{D}, 24,26 \mathrm{~A}, 27 \mathrm{~A}, 28$

Streblopus opatroides Van Lansberge 1874a: 10.

Streblopus opatroides - Ritsema 1888: 209. — Gillet 1911: 42. — Lucas 1920: 617. — Paulian 1939: 26-27. — Balthasar 1941: 345; 1951: 331. — Blackwelder 1944: 203. — Pereira \& Martínez 1956: 99. — Vulcano \& Pereira 1964: 580; 1967: 549. — Halffter \& Martínez 1966: 153-162, 165, figs 13-17. — Vaz-de-Mello 2000: 195. — Krajcik 2006: 163; 2012: 249. — Molano-Rendón \& MedinaUribe 2010: 692. — Vaz-de-Mello et al. 2011: 66, fig. 161. — Carvajal-López 2012: 195. — Medina et al. 2013: 461, 463, 473, fig. 65. - Audino et al., 2014: supplementary data 3. - Ratcliffe et al. 2015: 196. - Tarasov \& Génier 2015: 55, 64, 76, figs 4-7, 9, 30d-f, 35p, 44c. - Chamorro et al. 2019: 234. — Cupello \& Vaz-de-Mello 2019: 168-171.

\section{Material examined}

Lectotype (here designated)

BRAZIL - O'; Bahia; "LECTOTYPE § / Streblopus / opatroides / van Lansb. / des. F.Z.Vaz-de-Mello, 2014" [FZVM's handwriting], "Streblopus / opatroides / Lansberge / det. G. Halffter '66" [Gonzalo Halffter's handwriting], "Streblopus / opatroides / Bahia Lansb" [Van Lansberge's handwriting], "Museum Paris / ex Coll. / R. Oberthur", "Ex-Musæo / E. Harold", "TYPE"; genital capsule extracted and glued to a paper card, ex Edgar von Harold and R. Oberthür collections (Fig. 1C-D); MNHN.

\section{Paralectotypes}

BRAZIL • +; "Streblopus / opatroides / Lansb / Brésill" [Van Lansberge's handwriting], "cf. Col.Hefte / XII, 1874, p. 10" [unknown handwriting], "Colonychus / Har." [unknown handwriting], "type / (etiq. de l'auteur" [unknown handwriting], "J.J. Gillet det., vend.: / Streblopus / opatroides Lansb. / R.M.H.N. Belg.10.640" [unknown handwriting], "Ex-Typis", "PARALECTOTYPE + / Streblopus opatroi- / des Van Lansberge / labelled by Cupello, 2019" [MC's handwriting]; ex J.J. Gillet collection; RBINS • Remaining paralectotypes unknown.

Other material $(40 \hat{\partial} \hat{\partial}, 24$ 우)

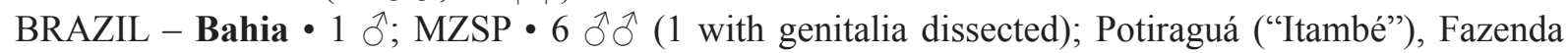
Independência; $15^{\circ} 42^{\prime} 39^{\prime \prime}$ S, 39³4'08" W; 245 m a.s.1.; 5 Feb. 2009; J.G. Mota-Souza leg.; pitfall baited with human faeces; CEMT -5 đิ̊; Maraú, Área de Proteção Ambiental (APA) da Baía de Camamu; $14^{\circ} 09^{\prime} 38.3^{\prime \prime} \mathrm{S}, 39^{\circ} 00^{\prime} 23.3^{\prime \prime} \mathrm{W} ; 27$ Nov. 2014; C.M.Q. Costa et al. leg.; pitfall baited with human faeces; CEMT $\bullet 1$ J, 1 q (left antenna, mouthparts and genitalia dissected); Porto Seguro; 15 Jul. 1990; E. and P. Grossi leg.; ex Everardo and Paschoal Grossi collection; CEMT • 1 ơ; Porto Seguro; Jul. 1993; E.

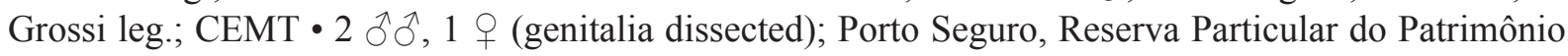
Ambiental (RPPN) Estação Veracel (“RPPN / Esta 500 Vera Cel”); Dec. 2004; J. Louzada leg.; ex W.D. 
Edmonds collection; TAMU $\bullet 2$ 2 (1 with genitalia and right wing dissected); Porto Seguro, RPPN

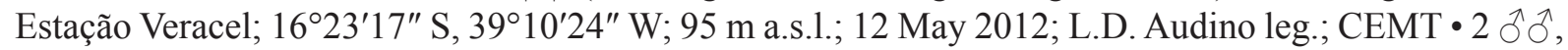

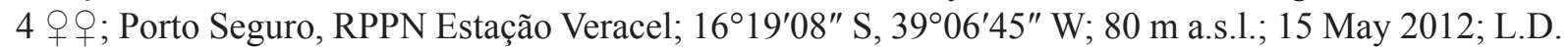
Audino leg.; CEMT -3 $\widehat{\lambda}, 5$ 우 (1 with genitalia dissected); Porto Seguro, RPPN Estação Veracel; 16²2'33" S, 3908'54" W; 95 m a.s.1.; 18 May 2012; L.D. Audino leg.; CEMT • 1 §’; Porto Seguro, RPPN Estação Veracel; 16²3'16" S, 39¹0'01" W; 65 m a.s.1.; 3 Jun. 2012; L.D. Audino leg.; CEMT •

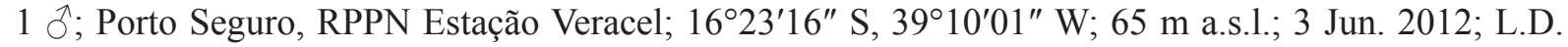
Audino leg.; TAMU • 1 q; Santa Teresinha, Serra da Jiboia; 1251'11.3" S, 39²8'32" W; 800 m a.s.1.; 8 Jun. 2007; Rafael and Xavier Francisco leg.; hand collection; ex Everardo and Paschoal Grossi collection; CEMT $\bullet 9$ ô (1 with left antenna, mouthparts, both posterior wings and genitalia dissected, 2 with genitalia dissected); Uruçuca, Parque Estadual da Serra do Conduru; 14²9'42.6" S, 3908'17.2" W; 27 Sep. 2014; C.M.O. Costa et al. leg.; pitfall baited with human faeces; CEMT • 1 q; Uruçuca, Parque Estadual da Serra do Conduru; 14²9'42.6" S, 3908'17.2" W; 27 Sep. 2014; C.M.O. Costa et al. leg.; pitfall baited with human faeces; DZUP • 1 సं; Valença, Cachoeira do Candengo; 3 Mar. 1987; Johann Becker (“J.B.") leg.; MNRJ. - Espírito Santo • 1 क; Descourtilz leg.; ex Fry collection; BMNH • 1 え (genitalia dissected); Linhares; Oct. 2004; P.C. Grossi leg.; ex Everardo and Paschoal Grossi collection; CEMT • 1 ô (genitalia dissected); Linhares, Fazenda Lagoa do Macuco; $19^{\circ} 03^{\prime} 50^{\prime \prime}$ S, 39 58 $43^{\prime \prime}$ W; 10 m a.s.1.; 27 Jan. 2000; F. Génier and S. Ide leg.; pitfall baited with dung; CEMT • 1 \%; Linhares, Reserva Natural Vale ("ResNatVal”); 1904'33" S, 3952'39" W; 7 Apr. 2016; F. Cassar leg.; pitfall with human faeces; CEMT • 1 \%; Linhares, Reserva Natural Vale ("ResNatVal"); 1906'18" S, 39॰57'52" W; 25 Jul. 2016; F. Cassar leg.; pitfall with human faeces; CEMT 1 ô, 1 q; Linhares, Reserva Natural Vale ("ResNatVal"); 1906'21" S, 3956'44" W; 25 Jul. 2016; F. Cassar leg.; pitfall with human faeces; CEMT • 1 O; Linhares, Reserva Natural Vale ("ResNatVal"); 1908'06" S, 3953'20" W; 25 Jul 2016; F. Cassar leg.; pitfall with human faeces; CEMT. - Rio Grande do Norte 1 o; ; Natal; dubious record; ex Boucomont and Van Lansberge collections; MNHN.

UNKNOWN LOCALITY • 1 \%; MNHN • 1 ঐ (possibly identified by Harold as Colonychus); ex Edgar von Harold and R. Oberthür collections; MNHN • 1 ô; ex E. Candèze collection; RBINS.

\section{Erroneous record}

COLOMBIA $・ 1$ đ; Tolima, Honda; ex Balthasar collection; NMPC.

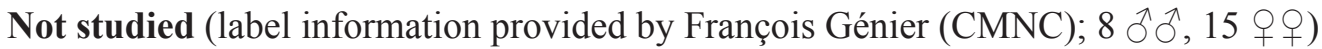

BRAZIL - Espírito Santo • 3 ภð, 9 우; Linhares, Fazenda Lagoa do Macuco; 1903'50" S, 39 58'43" W; 10 m a.s.1.; 25 Jan. 2000; F. Génier and S. Ide leg.; in Bruce Gill, Trond Larsen and

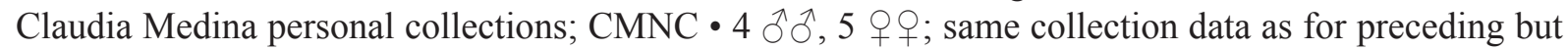
27 Jan. 2000; in Philippe Moretto personal collection; CMNC 1 ô, 1 क ; same collection data as for preceding but 28 Jan. 2000; in Bruce Gill personal collection; CMNC.

\section{Etymology}

As noted by Max Barclay (pers. comm. to MC, Sep. 2019), the specific name 'opatroides' is a clear reference to the overall morphological similarity, particularly of the shape of the pronotum, of this species to the widespread Opatrum Fabricius, 1775 tenebrionids. Such a similarity is, of course, completely analogous. According to Gemminger (1870), Opatrum (or Hopatrum) comes from the Greek word meaning 'same father' (or eodem patre, in Gemminger's Latin translation of the name).

\section{Redescription}

Measurements. Males $(27$ spec.): TL: AV 14.05, MX 17.25, MN 10.5. EW: AV 9.29, MX 11.68, MN 8.0. PW: AV 8.22, MX 10.69, MN 6.9. - Females (22 spec.): TL: AV 14.32, MX 15.9, MN 12.0. EW: AV 9.39, MX 10.56, MN 8.64. PW: AV 8.49, MX 9.92, MN 7.28. 
Colouration. Antennal club with yellowish tegument and pubescence. Dorsal and especially ventral colouration variable, presumably geographically: mostly populations with dorsum mostly light to dark brown, with reddish and olivaceous silky reflections throughout tegument, but particularly at outer limits of head and pronotum, at base and outer limits of elytra and throughout pygidium; venter, including surface of legs, completely covered by strong reddish sheen; populations in southeast Bahia with dorsum and venter completely devoid of, or with very discreet, silky sheen, almost completely dark brown, sometimes venter almost entirely black.

HEAD. Canthus long, digitiform (Fig. 5E). Clypeal process a short transverse carina, rounded at apex (Fig. 6A). Antennae with 9 articles; first article of funicle evidently shorter than rest of funicle combined
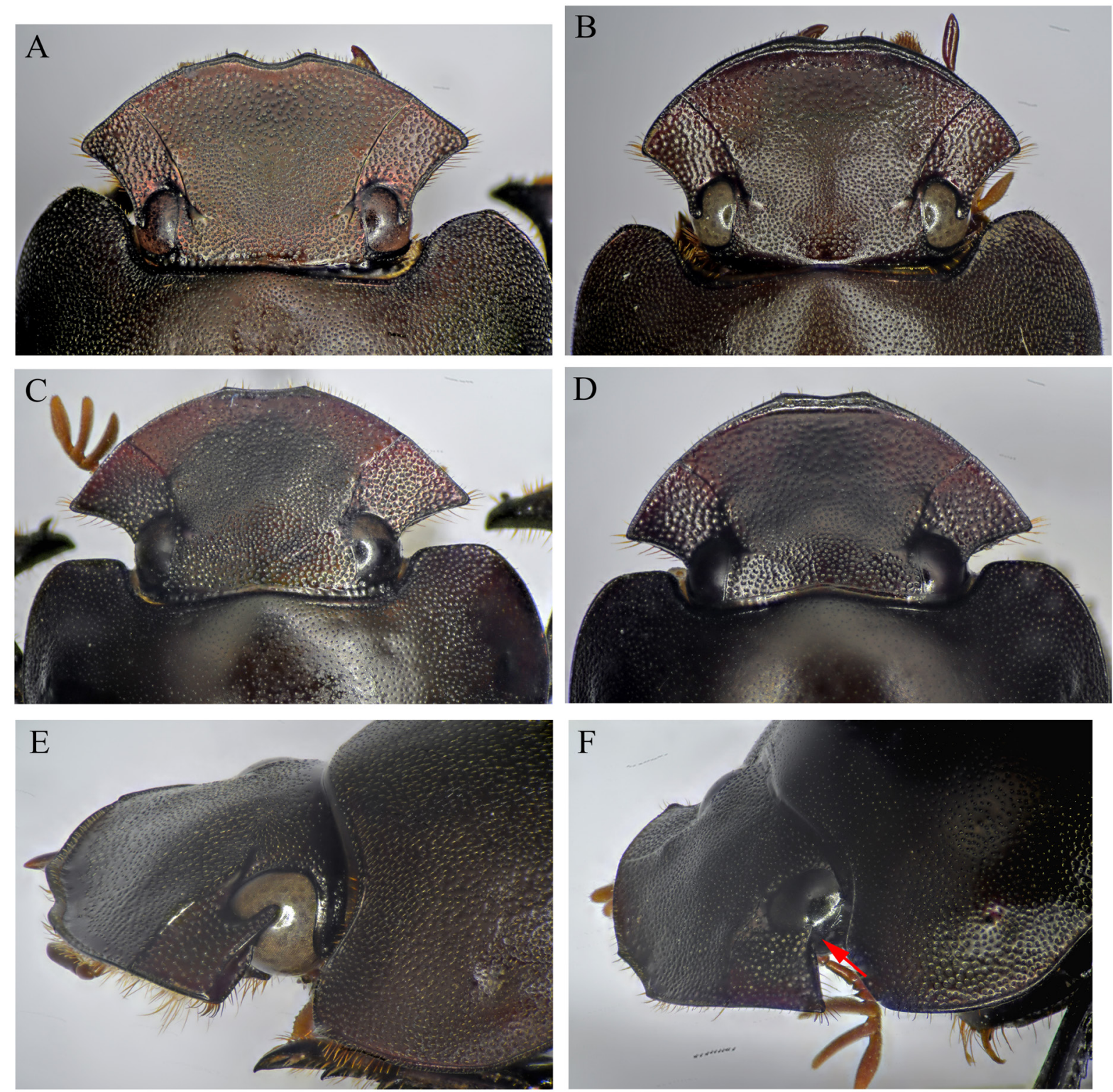

Fig. 5. Head. A-D. Dorsal view. A-B. Streblopus opatroides van Lansberge, 1874. A. đ. B. $q$. C-D. S. punctatus (Balthasar, 1938). C. O. D. . . Note how the emargination of the apex of the clypeus varies between the species and sexes, being greater in males of $S$. opatroides than in males of S. punctatus and females of both sexes. E-F. Lateral view. E. S. opatroides. F. S. punctatus. Red arrow indicates the canthus. Observe that the canthus is much longer in $S$. opatroides than in $S$. punctatus. 
(Fig. 7A). Labrum with anterolateral projections well projected and with external margin softly rounded; anterior labral margin broad, anterolateral projections widely separated; epipharynx with long medial brush and median area not so densely covered by long, thin setae, which leave a broad, glabrous central area (Fig. 8C-D).

Thorax. Pronotum with entire surface covered by dense umbilicate punctation; punctation denser from centre towards sides and anterolateral angles, but punctures never confluent (Fig. 12A); umbilicate punctures covering even margins; tegument between punctures with diffuse microsculpture. Prosternum, mesoventrite, mesanepisterna, metanepisterna and metaventrite entirely covered by dense umbilicate punctation and diffuse microsculpture between punctures (Fig. 13B-D); umbilicate punctation less dense towards anterior and posterior region of metaventrite.

Legs. Trochantofemoral articulation sexually dimorphic (see below). Mesocoxae with most of surface covered by umbilicate punctation, except anterior half with wide areas of smooth tegument. Mesofemora with or without brush of setae on posterior edge depending on sex (see below) (Fig. 17A-B); ventral surface covered by dense umbilicate punctation, denser near posterior edge; tegument between umbilicate punctures with diffuse microsculpture, except near posterior edge, which is sexually dimorphic (see
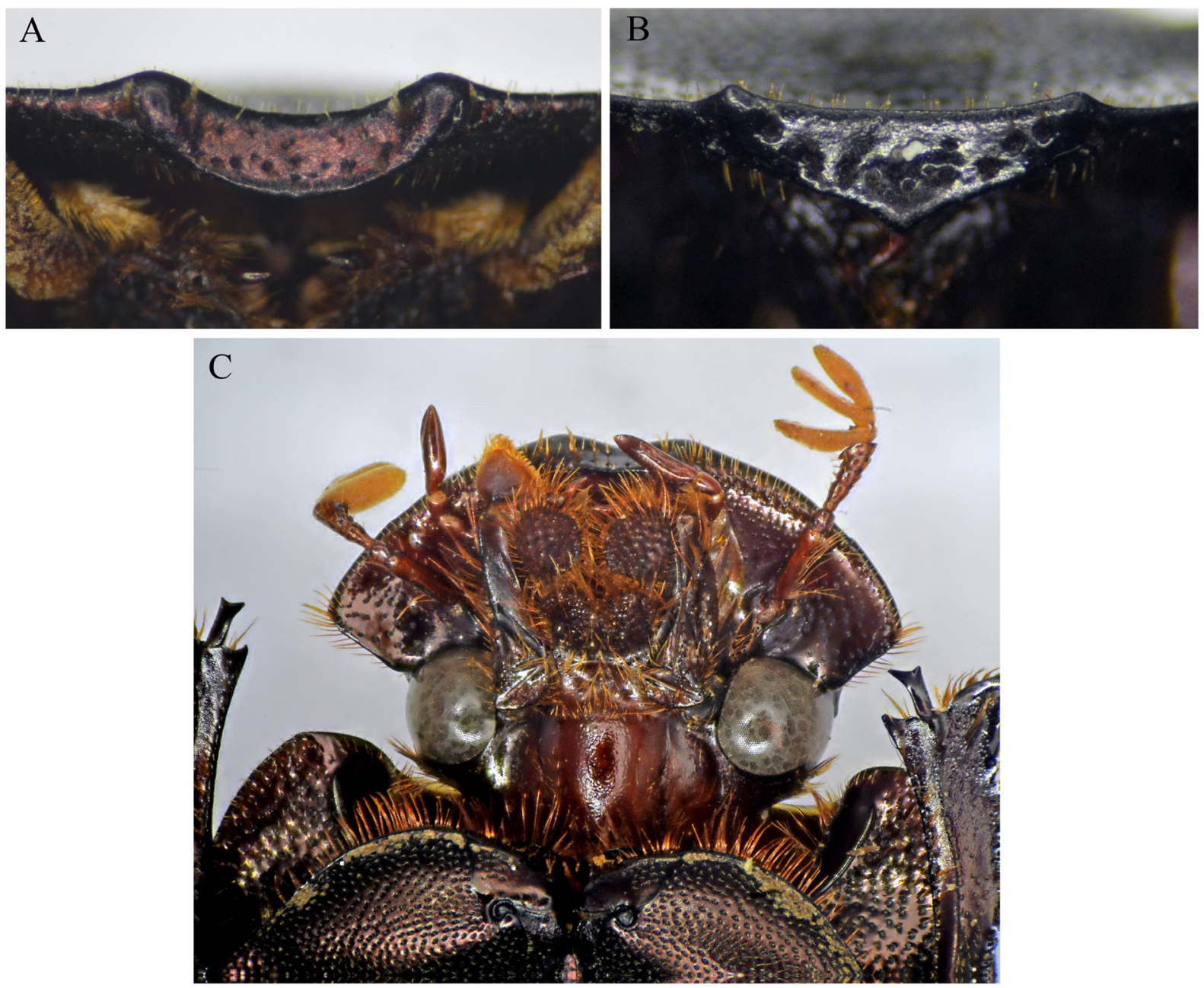

Fig. 6. Head. A-B. Clypeal process. A. Streblopus opatroides van Lansberge, 1874. B. S. punctatus (Balthasar, 1938). C. Ventral view of head, S. opatroides. 
below). Metafemora with posterior edge glabrous and without crenulation in both sexes (except brush of setae at male metafemoral spur); ventral surface with umbilicate punctation evenly distributed across most of surface, punctation denser near posterior edge (Fig. 19B-C). Metatibiae with ventral surface without umbilicate punctures or with umbilicate punctures limited to apical region (Fig. 20A-B).

WINGS. Elytra with striae fine, but always clearly impressed, never discontinuous; tegument covered by umbilicate punctation and well-delimited alveolar microsculpture between umbilicate punctures; alveoli sometimes ill-delimited and microsculpture more diffuse; lateral carina (pseudepipleural carina) completely interrupted by row of umbilicate punctures (Fig. 21B); apices of elytra not strongly deflected; distal calluses only slightly projected (Fig. 21D). Hing wing with a deep notch at area of anal fold; venation as in Fig. 21F.

Terminalia. Aedeagus: Right paramere with discreet, though still clearly discernible, apical projection (Fig. 23A-D); parameres, in dorsal view, with external edges curved (Fig. 23A); in lateral view, ventral region with well-projected keel and clear inclination towards apex (Fig. 23B-C). Internal sac with well-

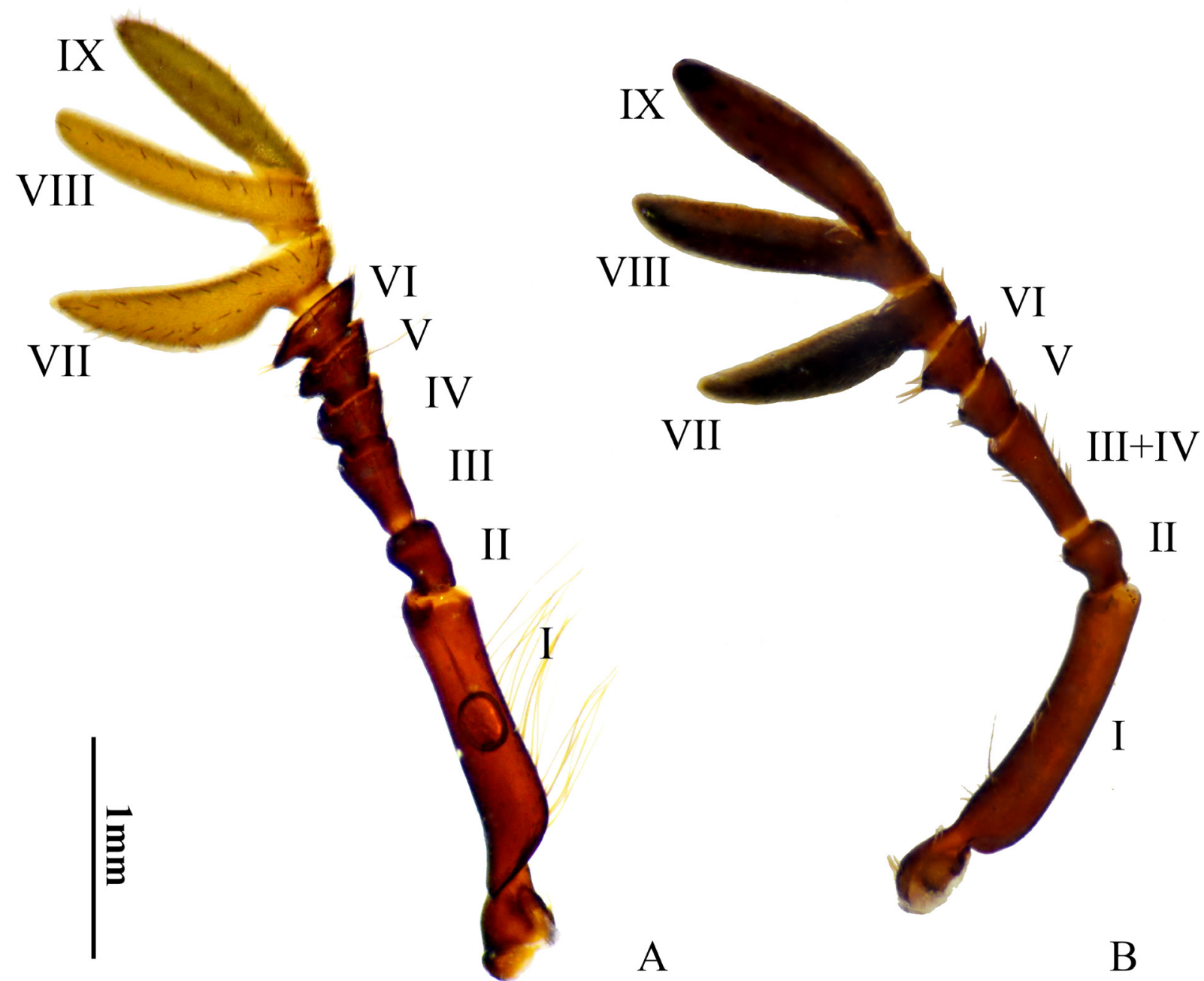

Fig. 7. Antennae. A. Streblopus opatroides van Lansberge, 1874. B. S. punctatus (Balthasar, 1938). Note the differences between the two species concerning the colour of the apical flagellomeres and the number and shape of the articles. In S. punctatus, the suppression of arthrogenesis between ancestral articles III and IV has resulted in a reduction of the total number of antennomeres from 9 to 8 . 

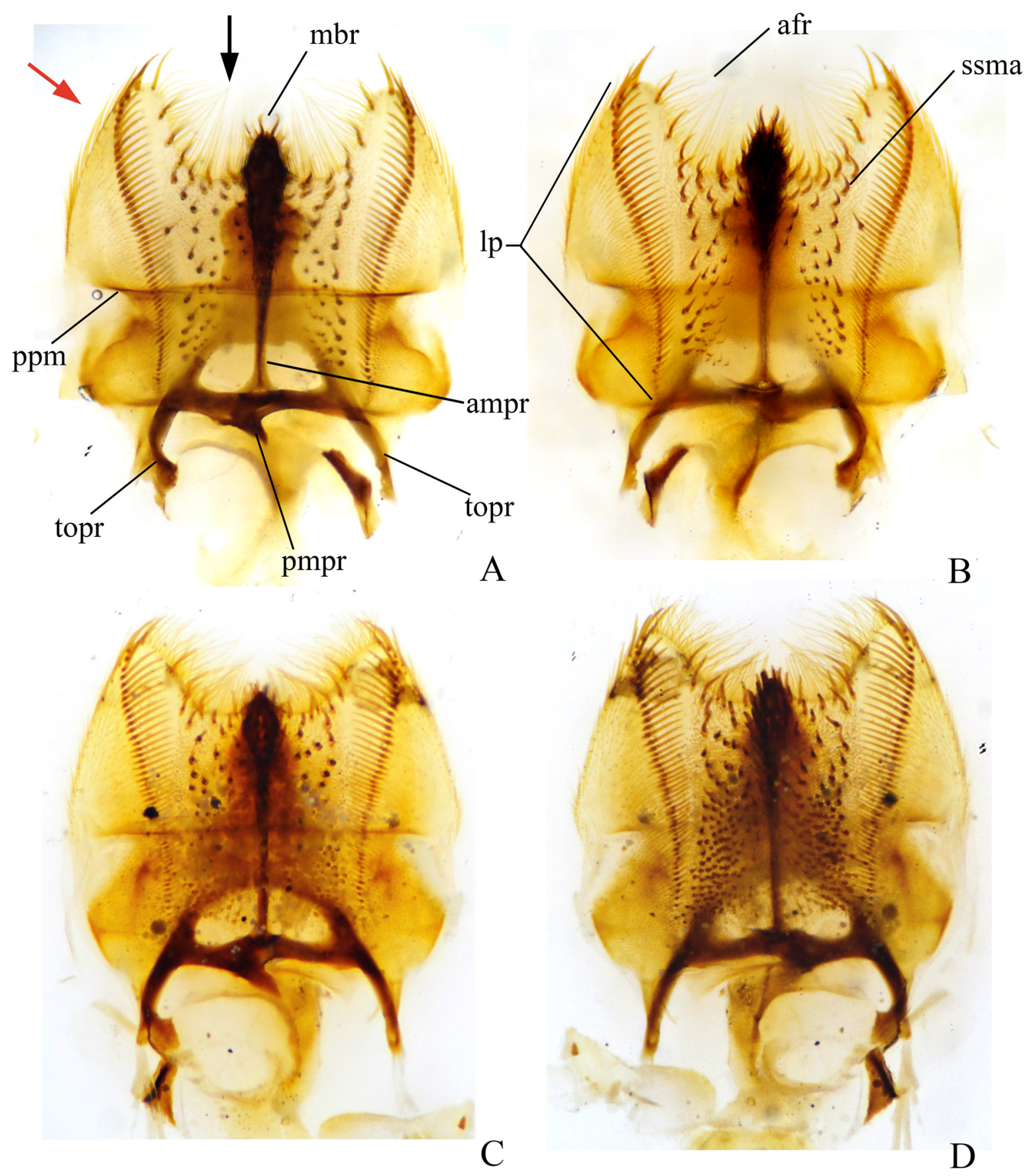

Fig. 8. Labrum. A-B. Streblopus opatroides van Lansberge, 1874. A. Aboral surface (dorsal view). B. Oral surface (ventral view; epipharynx). C-D. S. punctatus (Balthasar, 1938). C. Aboral surface. D. Oral surface. Note the many differences between the two species, particularly the much denser and shorter setation of the median area in S. punctatus, the much longer median brush of S. opatroides and the dissimilarities in the shape of the anterior epypharingeal margin. The black arrow shows the anterior margin of the labrum, while the red arrow indicates the anterolateral region. Abbreviations: $a f r=$ apical fringe of labrum; ampr = antero-median process of labral suspensorium; if $=$ lateral files; $\mathrm{mbr}=$ medial brush of labrum; pmpr = postero-median process of labral suspensorium; ppm = proplegmatium; ssma $=$ socketed setae of median area; topr $=$ tormal process of labral suspensorium. 


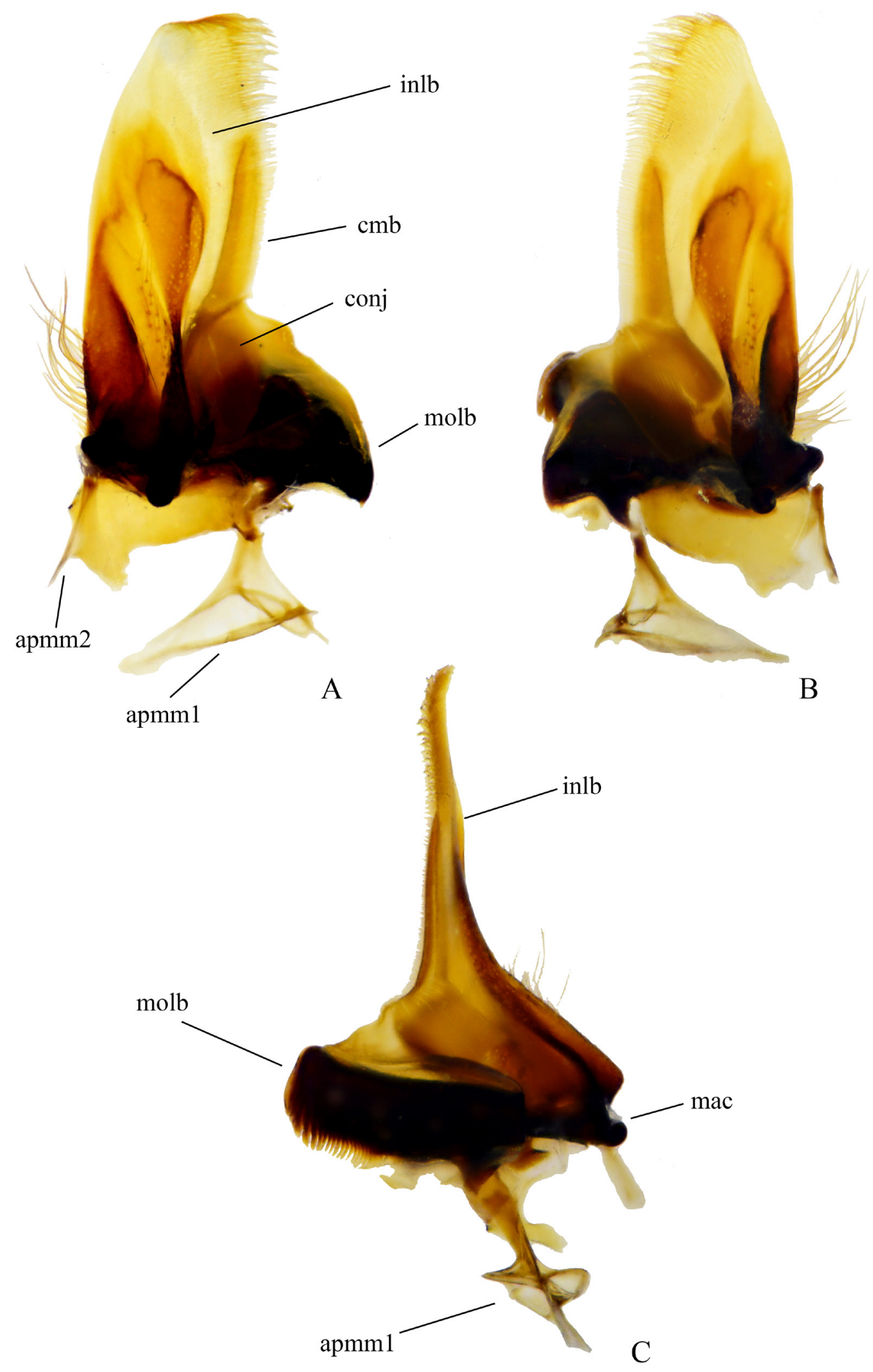

Fig. 9. Mandibles of Streblopus opatroides van Lansberge, 1874. A-B. Ventral view. A. Left mandible. B. Right mandible. C. Lateral view of right mandible. Abbreviations: apmm = apodemes of mandibular muscles; $\mathrm{cmb}=\mathrm{comb}$ of incisor lobe of mandible; conj = conjunctivus of mandible; inlb = incisor lobe of mandible; mac $=$ mandibular acetabulum; molb $=$ molar lobe of mandible. 
delimited and sclerotized sclerites: axial and subaxial sclerite similar in shape, both simply curved, falciform, axial sclerite shorter than subaxial (Fig. 24E-F). - Genital segment: Medial sclerotized plate (MSP) not so sclerotized, lateral arches concave; posterior arms of MSP only slightly indicated and with no clear emargination between them (Fig. 26B). - Spermatheca: Broad, in particular basal branch, without pair of apical hooks (Fig. 27A).

Sexual dimorphism. Male: Clypeus evidently emarginated at apex, with two tiny, but evident teeth flanking emargination (Fig. 5A). Metaventrite with deep and wide excavation on posterior region, marked anteriorly by strong spur (Fig. 13C). Profemora with anterior margin raised at centre into two strong spurs (Fig. 14A); trochantofemoral articulation with raised edge forming short spine. Protibiae as described above for genus; protibial spur absent (Fig. 15A, E). Mesofemora with basal half of posterior edge covered by brush of long setae (may be absent in very worn specimens) (Fig. 17A); area covered by brush of setae crenulated; near posterior edge, umbilicate punctures surrounded by dense alveolar microsculpture. Mesotibiae with internal edge with two longitudinal rows of long, dense setae (Fig. 18A). Metafemora with long spur on posterior edge, spur wavy and with brush of long setae at its external face (Fig. 19B). Metatibiae with row of sharp teeth at base on internal edge (Fig. 20A). - Female: Clypeus only slightly emarginated at apex, with rudimentary teeth flanking emargination (Fig. 5B). Metaventrite with shallower, narrower excavation on posterior region, with no anterior spur (Fig. 13D). Profemora more linear, anterior margin simple, not raised (Fig. 14B); trochantofemoral articulation not developed into spur. Protibiae with lateral teeth decreasing in size from apical to basal tooth; all lateral teeth apart from one another and always clearly directed laterally (Fig. 15B, F); protibial spur present, articulate,

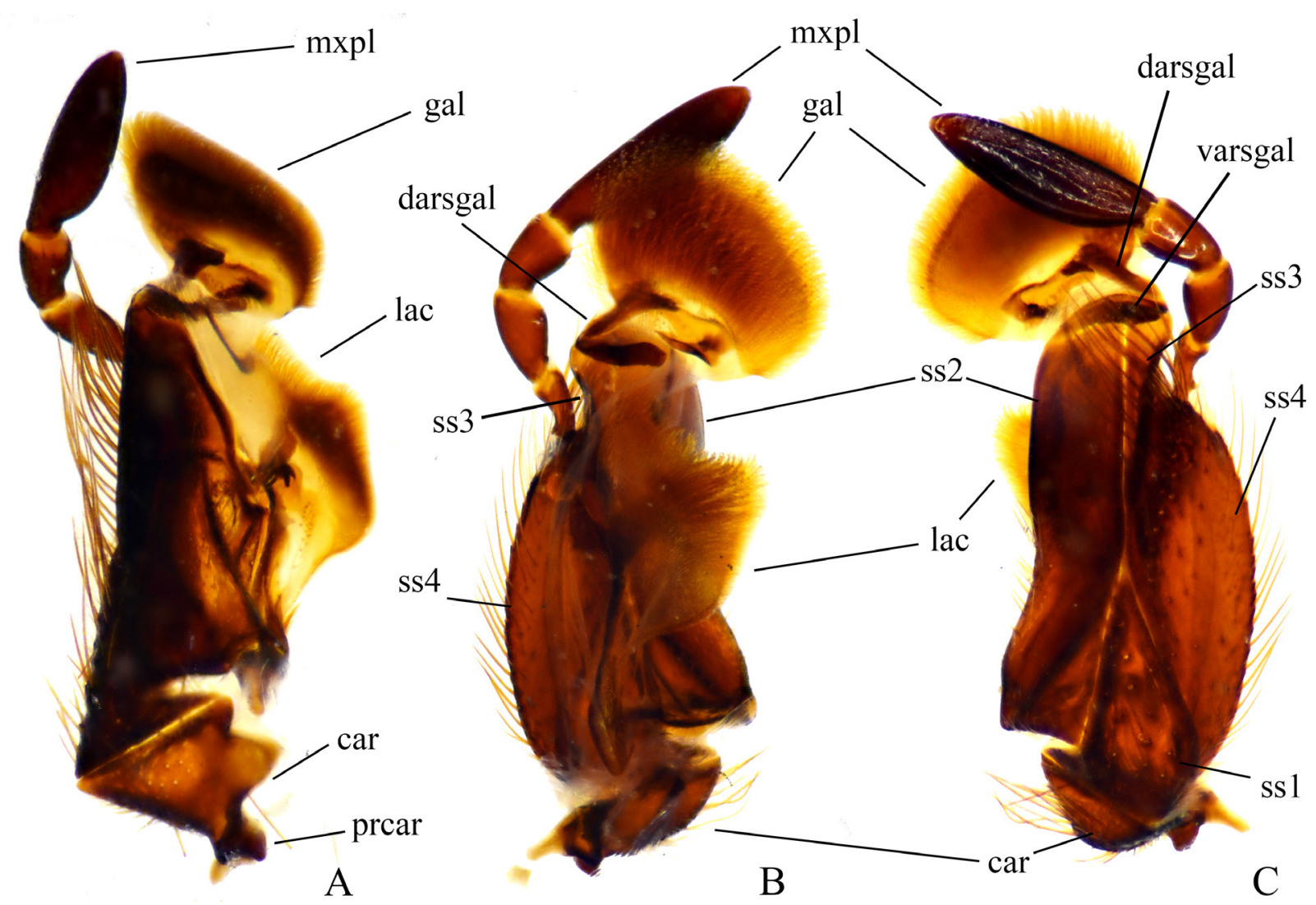

Fig. 10. Maxillae of Streblopus opatroides van Lansberge, 1874. A. Dorsal view with extended lacinia. B. Dorsal view. C. Ventral view. Abbreviations: car = cardo; darsgal = dorsal articular sclerite of galea; gal = galea; lac = lacinia; $\mathrm{mxpl}=$ maxillary palpus; prcar $=$ articular process of cardo; $\mathrm{ss} 1-4=$ stipal sclerite $1-4$; varsgal $=$ ventral articular sclerite of galea . 

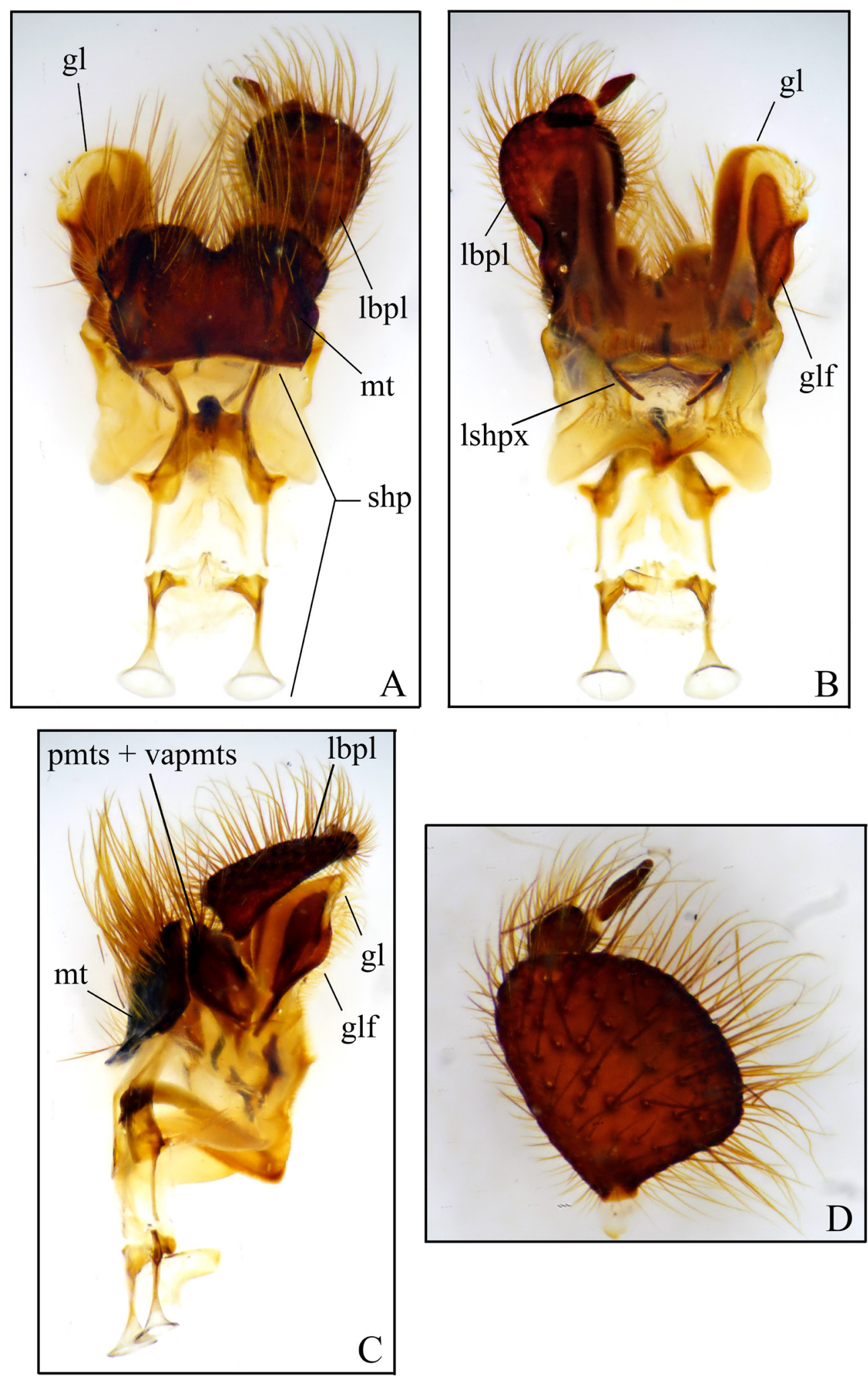

Fig. 11. Labium of Streblopus opatroides van Lansberge, 1874 (left palpus removed). A. Ventral view (aboral surface). B. Dorsal view (oral surface). C. Lateral view. D. Removed left palpus. Note the unusual shape of the palpus, with the basal palpomere remarkably enlarged. Abbreviations: $\mathrm{gl}=\mathrm{glossa}$; glf = glossal flap; lbpl = labial palp; 1shpx = lateral hypopharyngeal sclerite; $\mathrm{mt}=$ mentum; pmts $=$ premental sclerite; $\operatorname{shp}=$ suspensorium of hypopharynx; vapmts = ventral angles of premental sclerites. 
bifurcated at apex, internal branch of bifurcation much longer than external branch, which is only indicated (Fig. 15B, F). Mesofemora lacking brush of setae on posterior edge (Fig. 17B); near posterior edge umbilicate punctures surrounded by diffuse microsculpture (as in rest of tegument of mesofemora). Mesotibiae with internal edge with sparse setae not forming a clear row (Fig. 18B). Metafemora simple, lacking posterior spur (Fig. 19C). Metatibiae smooth at base, without row of sharp teeth (Fig. 20B).
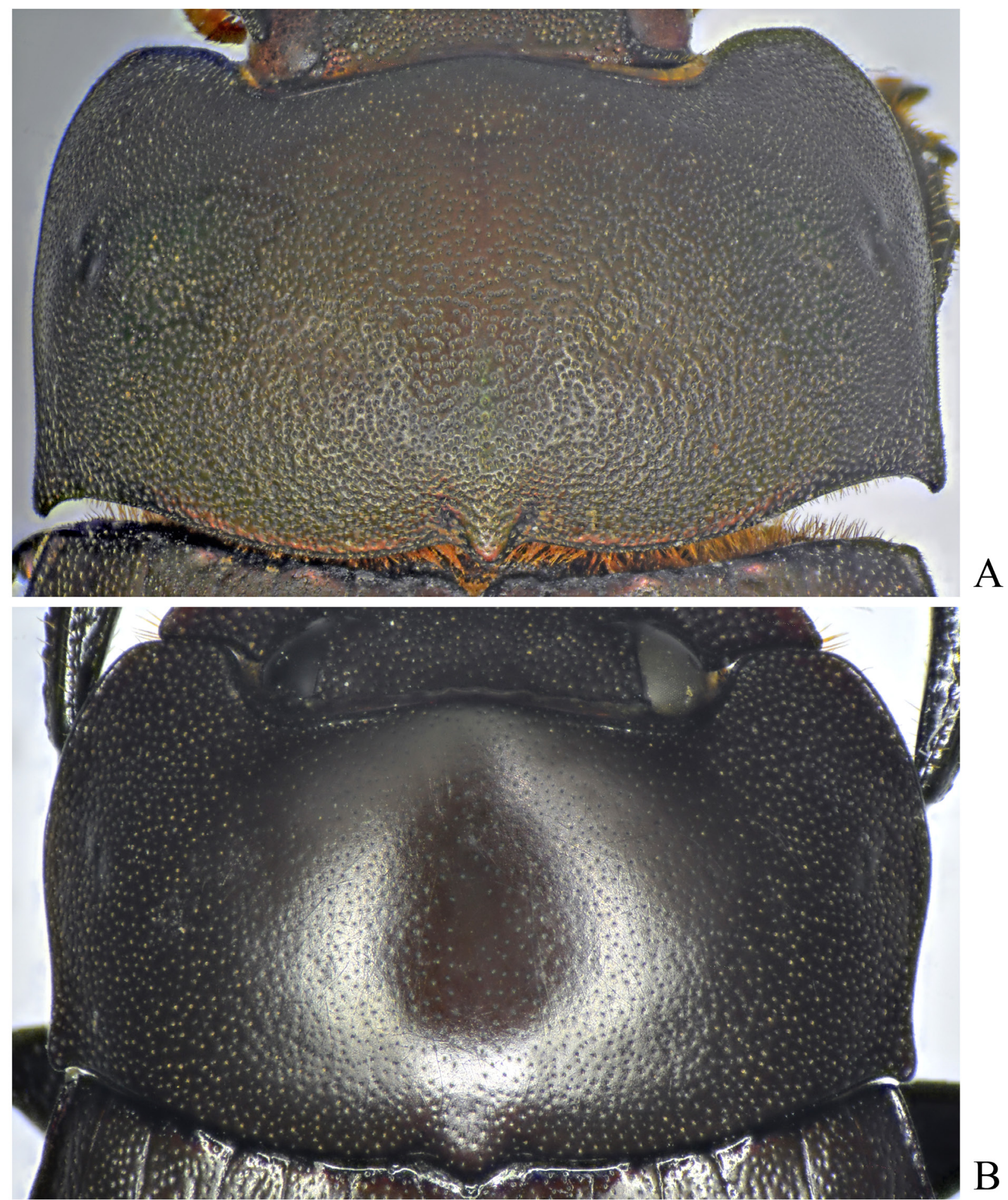

Fig. 12. Pronotum. A. Streblopus opatroides van Lansberge, 1874. B. S. punctatus (Balthasar, 1938). Note the differences in the umbilicate punctation and colour between the species. 


\section{Distribution}

Patches of coastal lowland Atlantic Forest in the Brazilian states of Bahia and Espírito Santo (Fig. 4).

Ecoregions. Bahia Coastal Forests.

Collection sites. Brazil - Bahia: Maraú (Área de Proteção Ambiental Baía de Camamu), Porto Seguro (Reserva Particular do Patrimônio Natural Estação Veracel), Potiraguá, Santa Teresinha, Uruçuca (Parque Estadual da Serra do Conduru), Valença; Espírito Santo: Linhares (Reserva Natural Vale).

\section{Intraspecific variation}

The most remarkable geographical variation presented by $S$. opatroides concerns colouration, particularly that of the venter (Fig. 2). Throughout much of the distribution of the species, including the only population known from Espírito Santo (Linhares) and several localities in Bahia (Porto Seguro, Potiraguá, Santa Teresinha and Valença), populations of $S$. opatroides show silky reflections of reddish and olivaceous tonalities over much of the predominantly brown dorsum, particularly at the outer limits of the head and pronotum, at the base and outer limits of the elytra, and on the entire pygidium, while

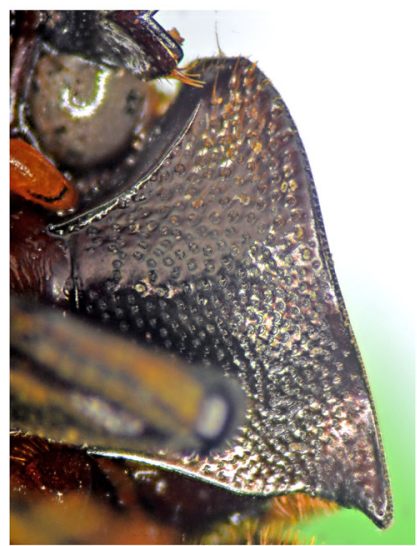

A

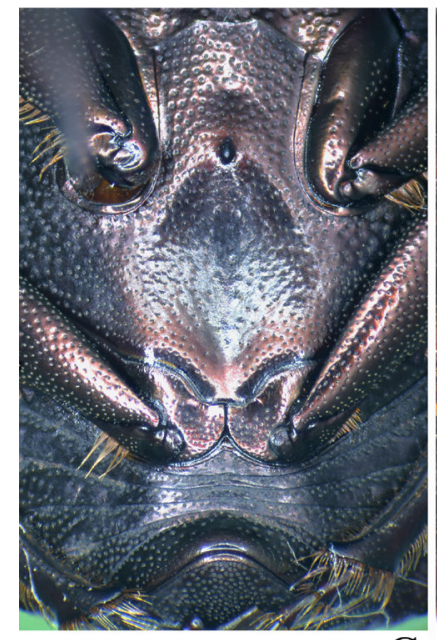

$\mathrm{C}$

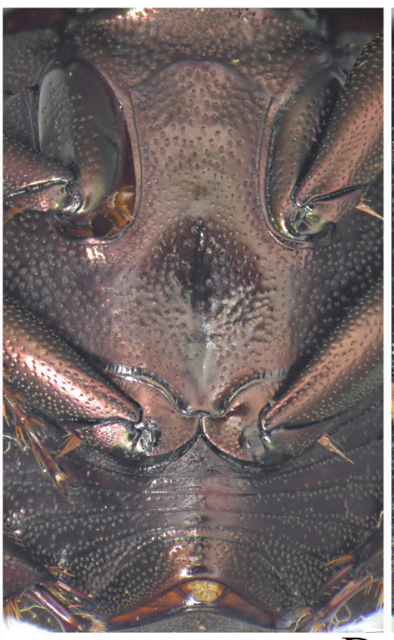

$\mathrm{D}$

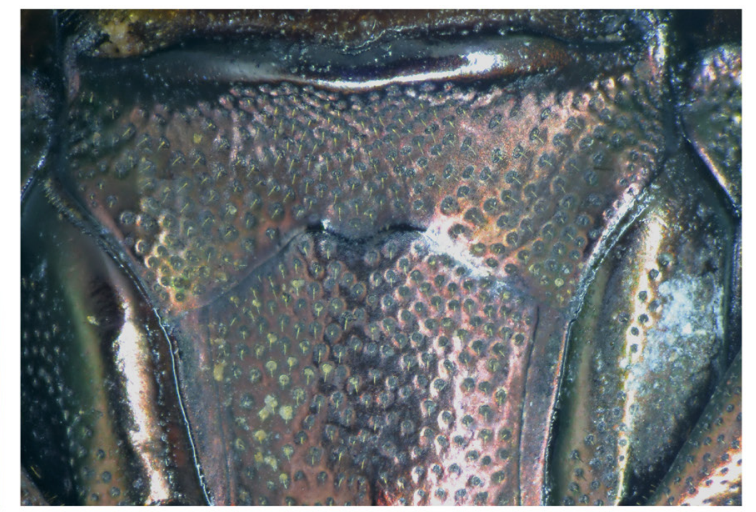

$\mathrm{B}$

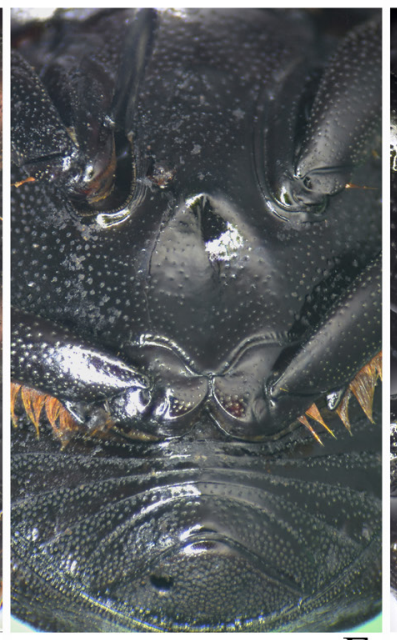

$\mathrm{E}$

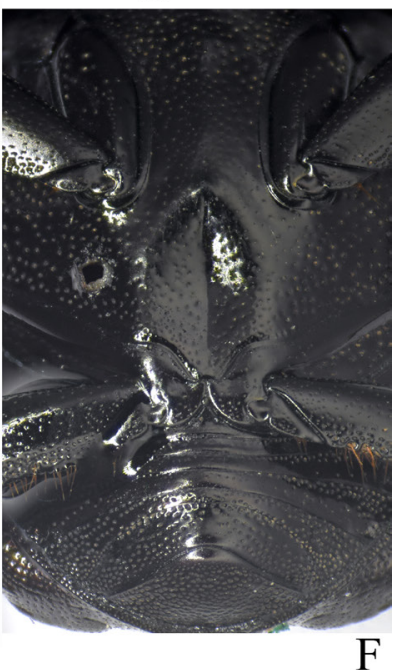

$\mathrm{F}$

Fig. 13. Venter. A-B. Streblopus opatroides van Lansberge, 1874. A. Hypomeron. B. Mesoventrite and anterior region of metaventrite. C-F. Metaventrite and abdomen. C-D. S. opatroides. C. $\widehat{\diamond}$. D. .. E-F. S. punctatus (Balthasar, 1938). E. O. F. O. Note in particular the distinction between the species and sexes in the shape of the concavity of the posterior region of the metaventrite. 
the venter bears a strong reddish metallic sheen covering the legs, hypomeron, prosternum, meso- and metaventrites and abdominal ventrites (Fig. 2). In a very limited region in southeast Bahia, however, more specifically in Maraú and Uruçuca, specimens are always much darker, show at most only some discreet reddish and olivaceous reflections on the dorsum and, most interestingly, completely lack the ventral metallic sheen seen in the other populations; instead, their venter is usually dark brown, sometimes even entirely black (Fig. 2). Unless this colour variation evolved in the mentioned populations during the $20^{\text {th }}$ century (which does not seem to be the case, since Harold's $19^{\text {th }}$ century specimen of Colonychus shows this darker ventral colouration), the lectotype and only known paralectotype of $S$. opatroides, whose provenance labels state only "Bahia" and "Brésil", respectively, most probably did not come from the southeastern region of that state, since their venter shows the more typical metallic colouration of the other populations of the species.

Initially, we investigated the possibility that the populations of southeast Bahia could represent a different species than $S$. opatroides, but our results show that this is probably not the case, since no other morphological or phenological features were shown to vary along with the ventral colouration. Indeed, for some yet unknown reason, dung beetle populations in the Atlantic Forest, especially in its more or less northern half, seem to be particularly prone to exhibit geographical colour variation, and some species such as Sylvicanthon obscurus (Schmidt, 1920) (Cupello \& Vaz-de-Mello 2018), Canthon (Goniocanthon) smaragdulus (Fabricius, 1781) (Nunes et al. 2018) and Phanaeus (Notiophanaeus) splendidulus (Fabricius, 1781) (Edmonds 1994; Edmonds \& Zídek 2012; and personal observations

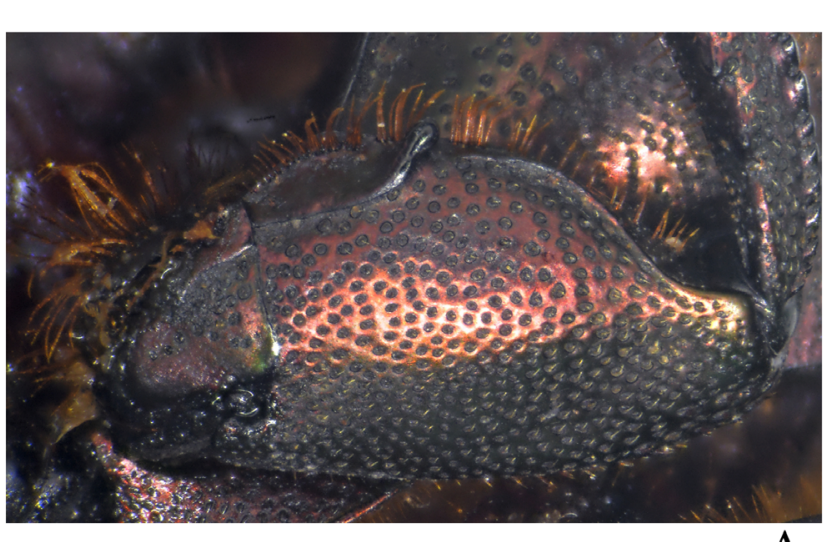

A

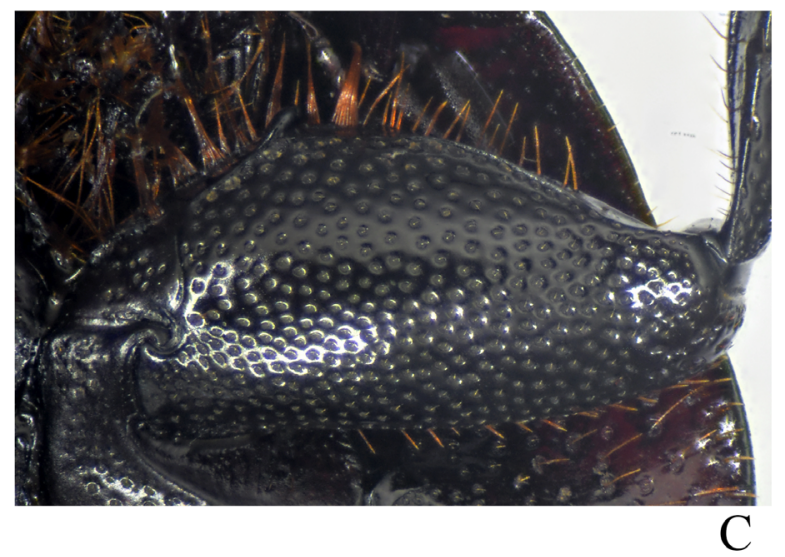

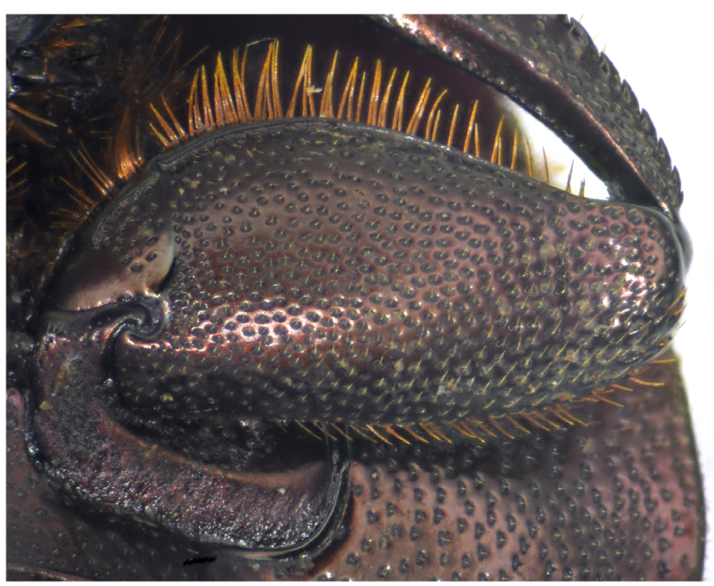

$\mathrm{B}$

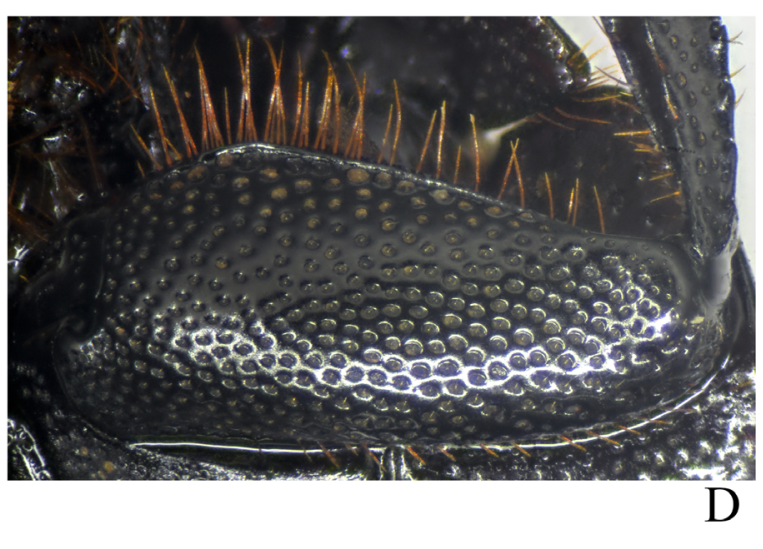

Fig. 14. Profemora. A-B. Streblopus opatroides van Lansberge, 1874. A. §. B. ․ C-D. S. punctatus (Balthasar, 1938). C. O. D. $q$. Note the differences between the species and sexes in relation to the overall shape of the profemora and the presence of spurs on the anterior edge in males. 
of the authors) are well-studied examples of this phenomenon. We believe that the interpopulational variation seen in $S$. opatroides is, therefore, just another instance of this general pattern, and future collections will reveal whether there exists a geographical intergradation between the two colour phases of $S$. opatroides observed in this paper and, if not, whether intermediate populations show individuals of both possibly-discrete phases.

Apart from colour, the only other noteworthy variation observed in S. opatroides concerns allometric differences in the sexual secondary characteristics of males. As usual in Scarabaeinae, smaller males

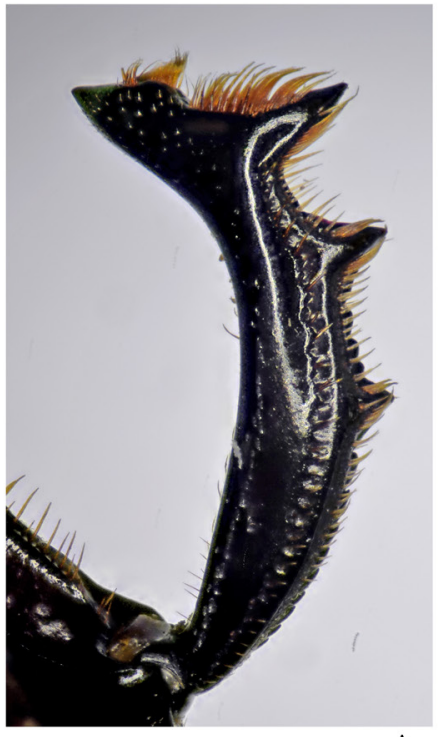

A

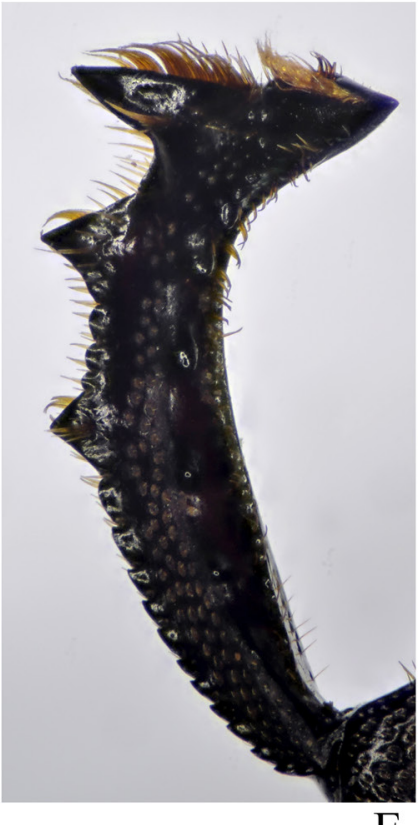

$\mathrm{E}$

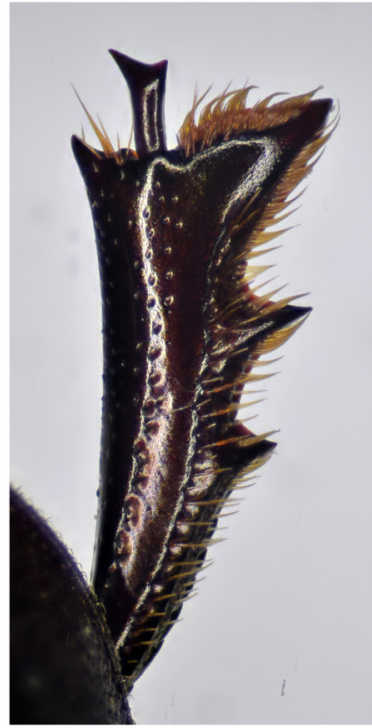

B

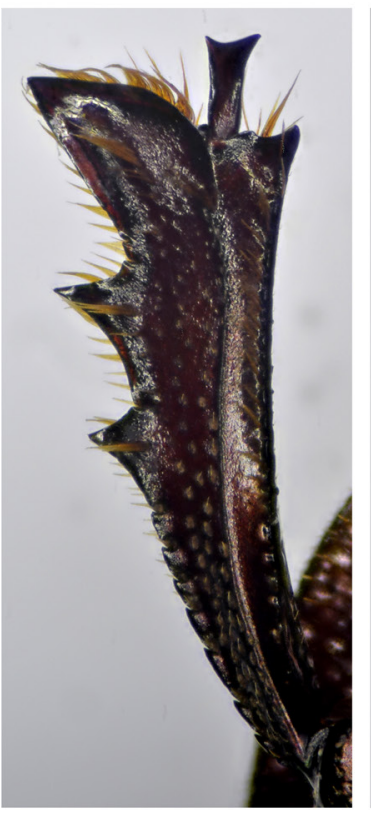

$\mathrm{F}$

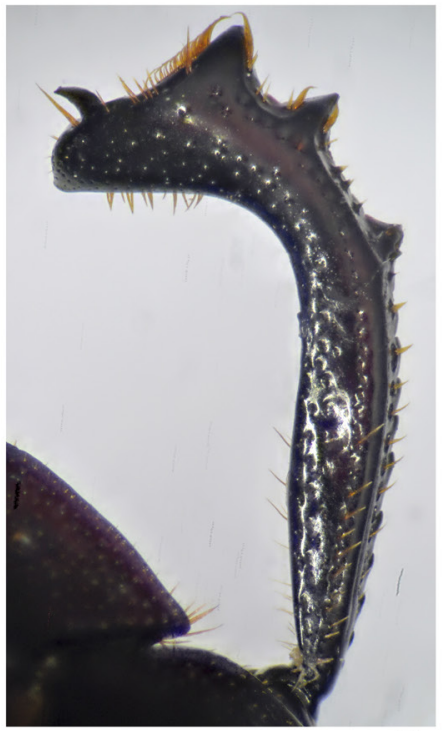

$\mathrm{C}$

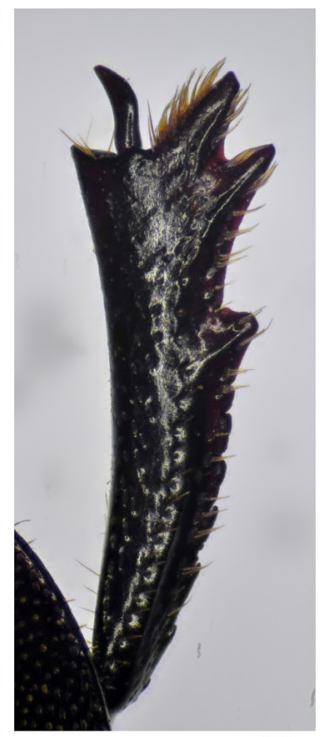

$\mathrm{D}$

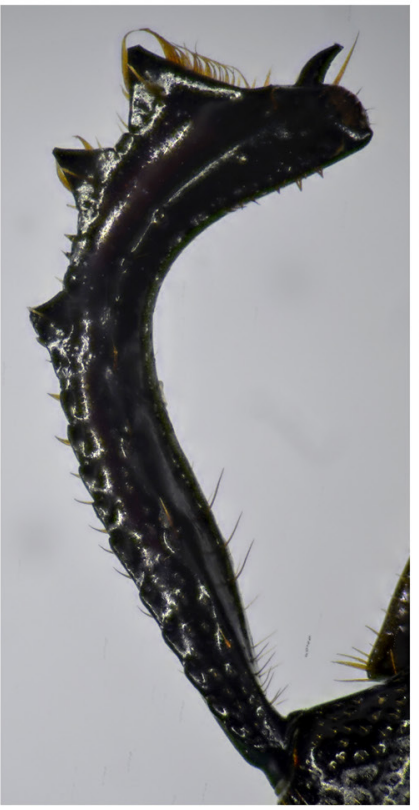

$\mathrm{G}$

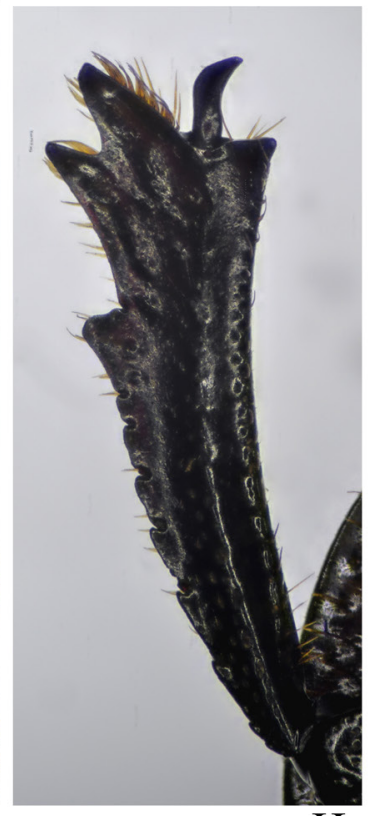

$\mathrm{H}$

Fig. 15. Protibiae. A-D. Dorsal view. A-B. Streblopus opatroides van Lansberge, 1874. A. §. B. ㅇ.

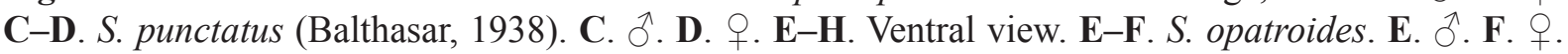
G-H. S. punctatus. G. ${ }^{\lambda}$. H. $q$. Notice the many differences between the species and sexes, in particular the presence of a protibial spur in males of $S$. punctatus (and its absence in $S$. opatroides) and the different shapes of the spurs and of the lateral teeth in females of the two species. 


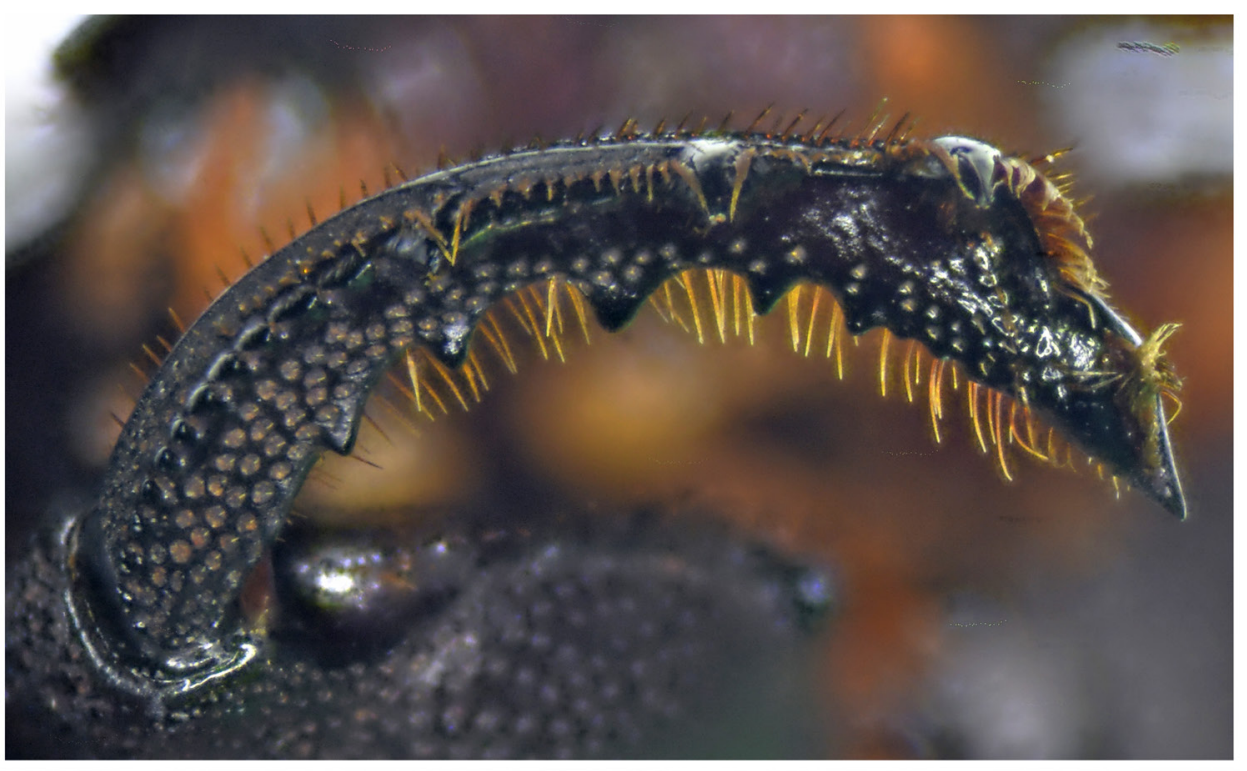

A

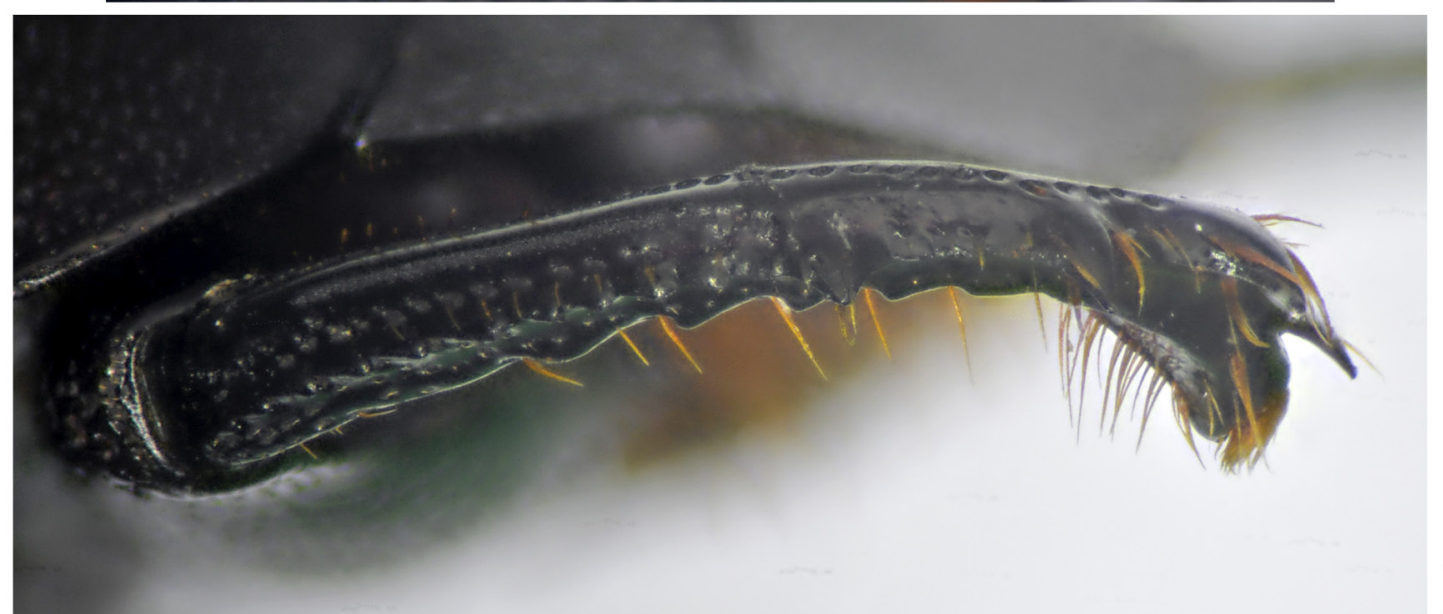

$\mathrm{B}$

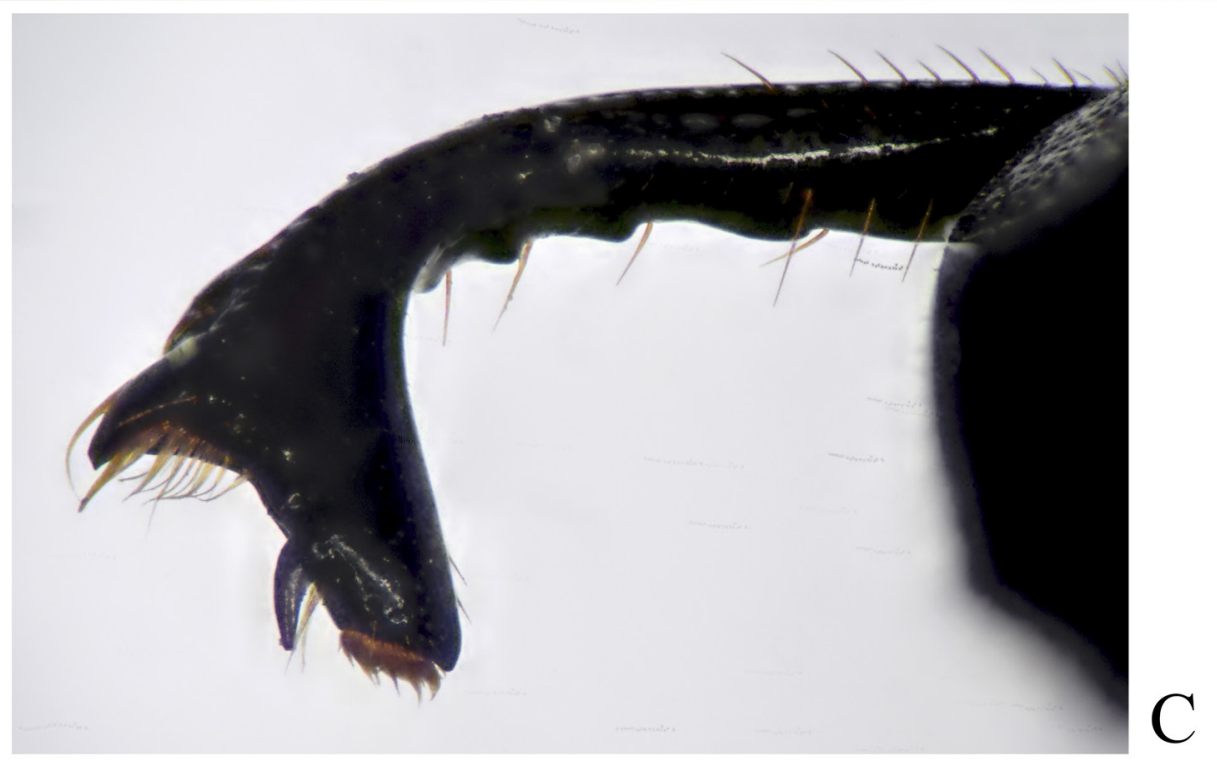

Fig. 16. Protibiae. A-B. Lateral view. A. Streblopus opatroides van Lansberge, 1874. B. S. punctatus (Balthasar, 1938). Note the how the protibia of $S$. opatroides is much more curved than that of S. punctatus. C. Frontal view of the protibia of S. punctatus. Note the presence of a protibial spur. 
have such features disproportionally less developed than larger males and, consequently, the smaller the males, the more similar they are to females. Thereby, in small males, profemora tend to have lessdeveloped anterior spurs (sometimes only one tiny spur is present instead of two), protibiae tend to be less twisted, the metafemoral spur tends to be shorter and protibiae tend to be less projected apically. However, no allometric variation was observed in the shape of the paramera or of the internal sac sclerites.

\section{Remarks}

It is remarkable that, although only relatively few specimens are known for this species, and most of them collected in the $21^{\text {st }}$ century, a large amount of mislabelling and many erroneous geographical records are found in collections and the literature. The NMPC male allegedly collected in Honda (Tolima, Colombia), for instance, is certainly mislabelled; this wrong provenance information was probably what led Vladimir Balthasar to identify it, with uncertainty, as S. punctatus ("Streblopoides cf. punctatus", as stated on one of its labels). Additionally, the MNHN male labelled "Natal", which possibly refers to the capital city of the Brazilian state of Rio Grande do Norte, is also probably incorrect as no other
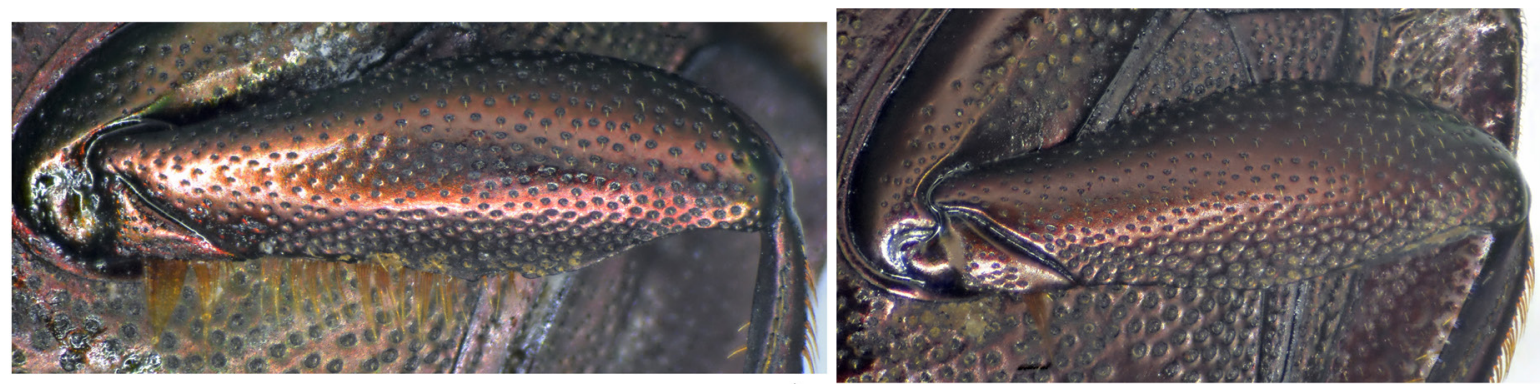

A
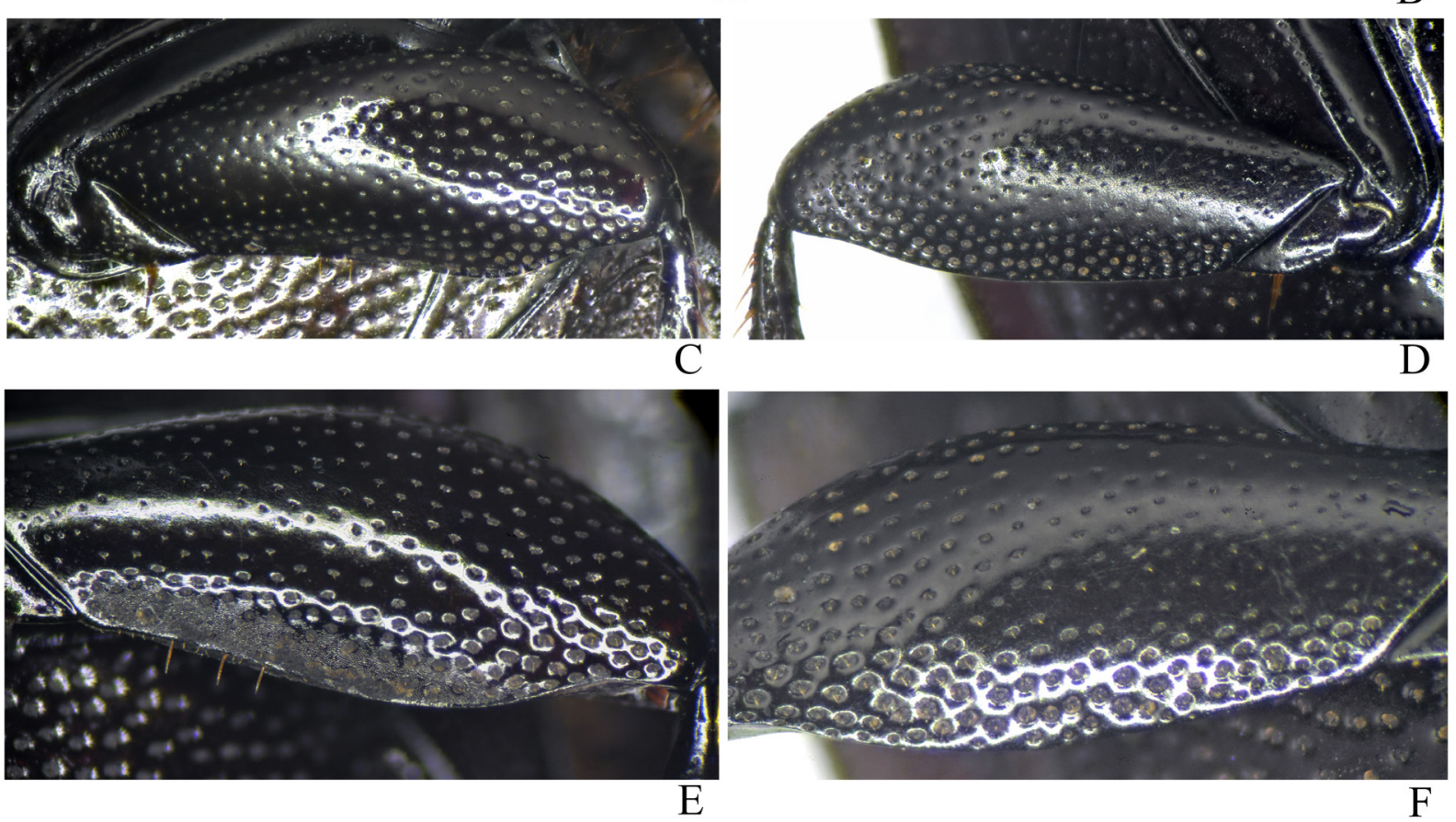

Fig. 17. Mesofemora. A-B. Streblopus opatroides van Lansberge, 1874. A. O̊. B. ๆ. Note the sexual dimorphism in the presence of a long row of setae on the posterior edge of the male mesofemur. C-F. S. punctatus (Balthasar, 1938). C. O. D. ․ . E-F. Detail of posterior region of metafemora. E. $\supset$. F. $q$. Note the strong alveolar microsculpture present near the posterior edge in males and the high concentration of umbilicate punctures in the same region in females. 

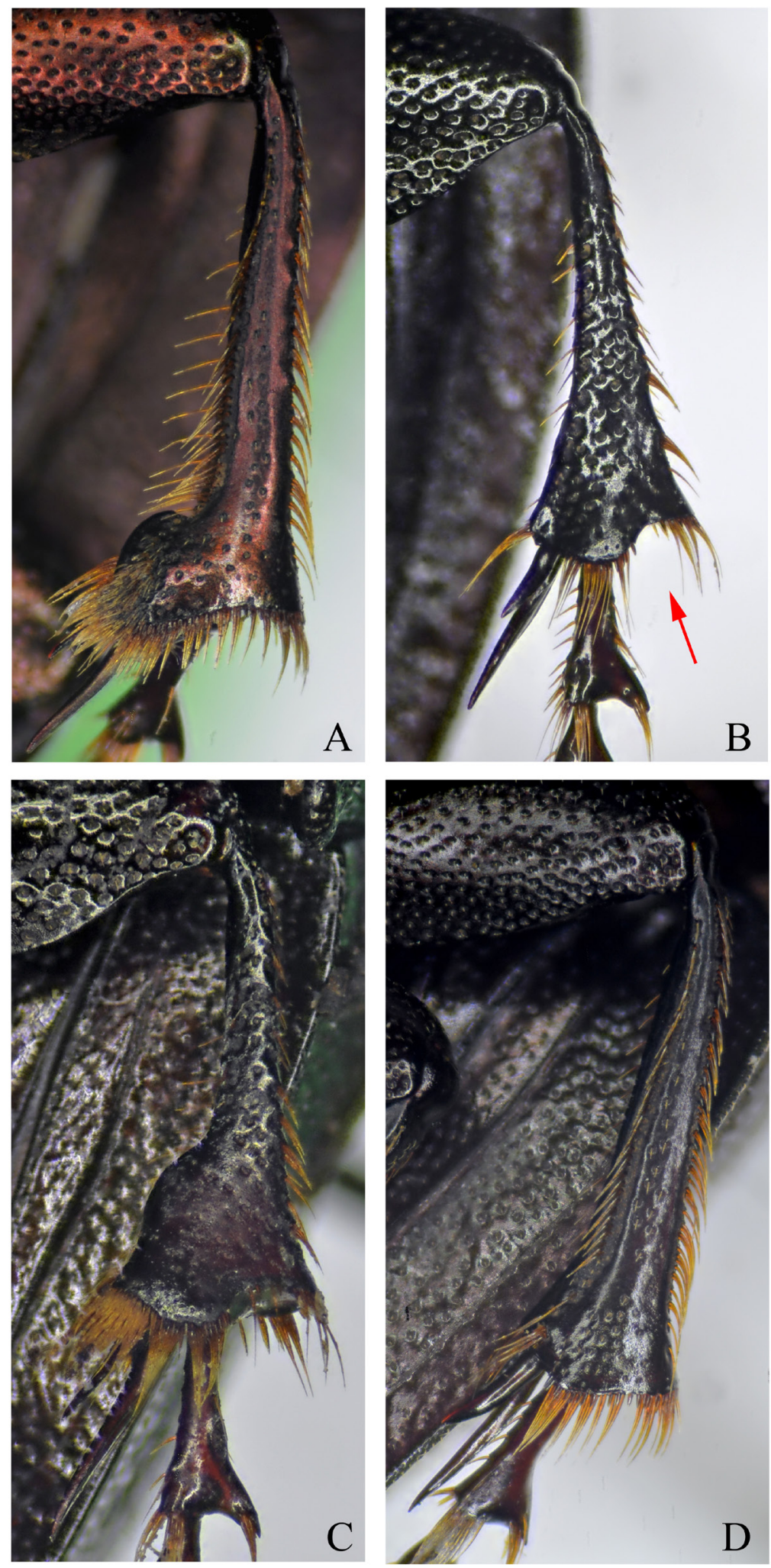

Fig. 18. Mesotibiae. A-B. Streblopus opatroides van Lansberge, 1874. A. ̊̊. B. ๆ. C-D. S. punctatus (Balthasar, 1938). C. O. D. . . Observe that females of S. opatroides differ from those of S. punctatus by having a deep emargination at the apical edge of the mesotibiae (red arrow shows emargination). 
specimens are known from the region north of Bahia State. As for the literature, Paulian's (1939) record of $S$. opatroides from Oxapampa (Pasco, Peru) is certainly incorrect and possibly refers to either a misidentified S. punctatus or a mislabelled S. opatroides; although this specimen originally belonged to the Boucomont collection, which is currently housed in the MNHN (Horn et al. 1990a), neither we nor Halffter \& Martínez (1966) were able to locate it. The incorrect record given by Paulian (1939) was repeated by Balthasar $(1941,1951)$, Pereira \& Martínez $(1956)$, Vulcano \& Pereira $(1964,1967)$ and as recently as Ratcliffe et al. (2015). As noted earlier by Halffter \& Martínez (1966), this species should be removed from the list of Peruvian dung beetles.

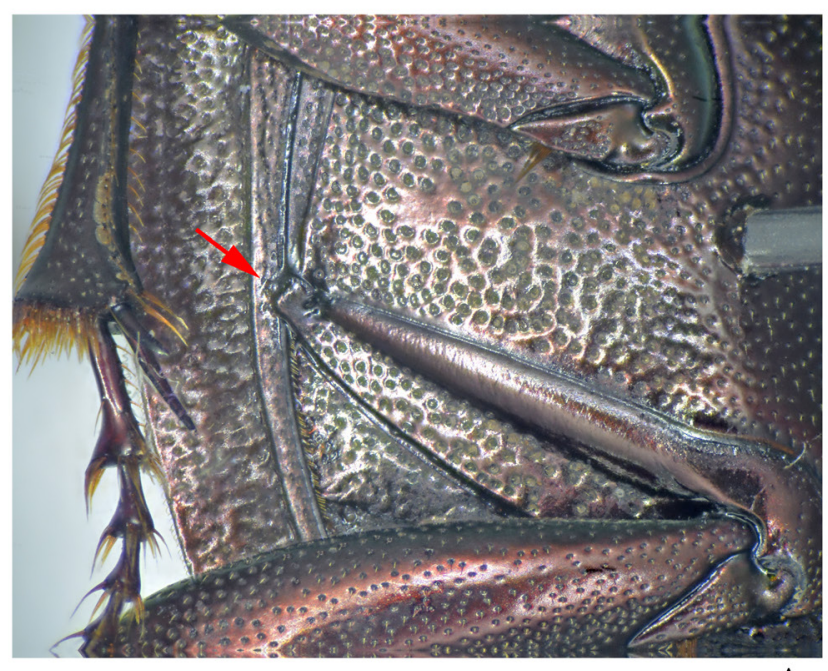

A
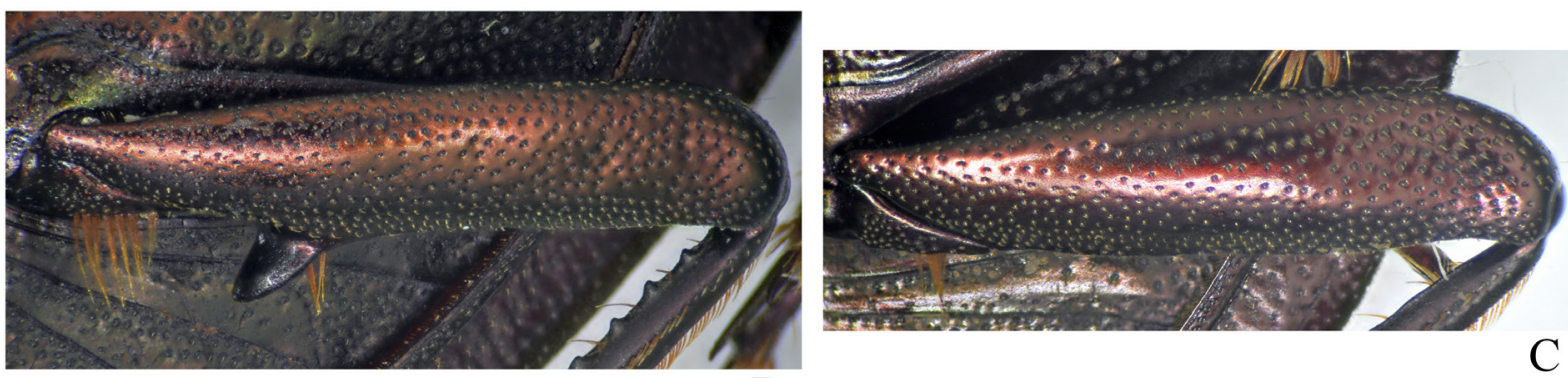

B

$\mathrm{C}$
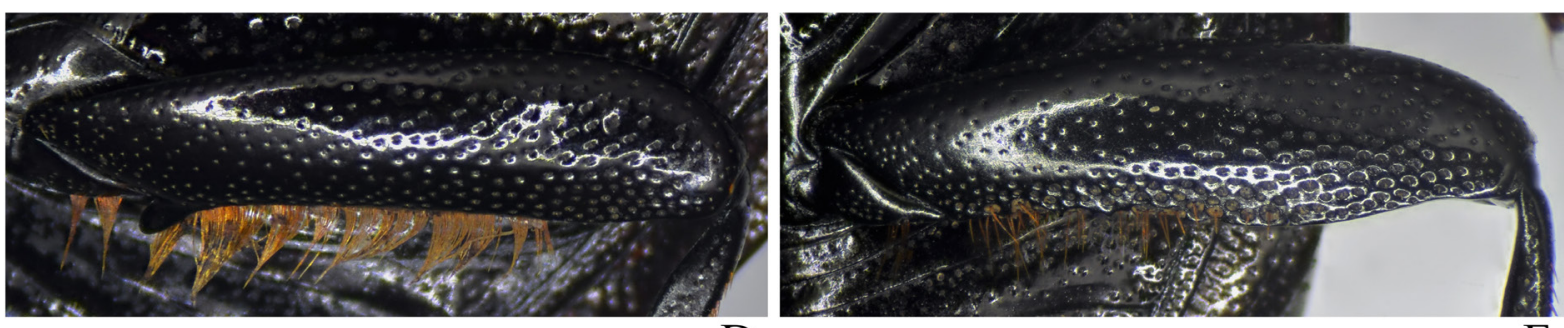

$\mathrm{D}$

$\mathrm{E}$

Fig. 19. Posterior legs. A. Metacoxa of Streblopus opatroides van Lansberge, 1874. Arrow shows the lateral spur present in both sexes of both species. Note also that the spur covers the epipleura and possibly maintains the elytra pressed against the body, thus avoiding loss of water or the entry of sediment beneath the elytra in a similar way to that hypothesized for the metanepisternal tab of the Phanaeini and other tunneller groups (Edmonds 1972; Cupello \& Vaz-de-Mello 2016). B-E. Metafemora and

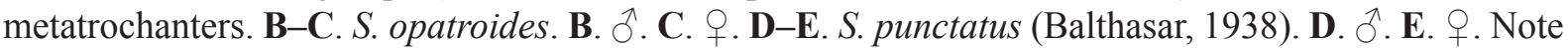
the strong sexual dimorphism and the many differences between the species. 
Although only one syntype was found by Paulian (1939), Halffter \& Martínez (1966) and ourselves in the MNHN, the museum that currently houses the Van Lansberge collection (Horn et al. 1990b), the original type series of S. opatroides certainly consisted of more than one specimen, since Van Lansberge (1874a)
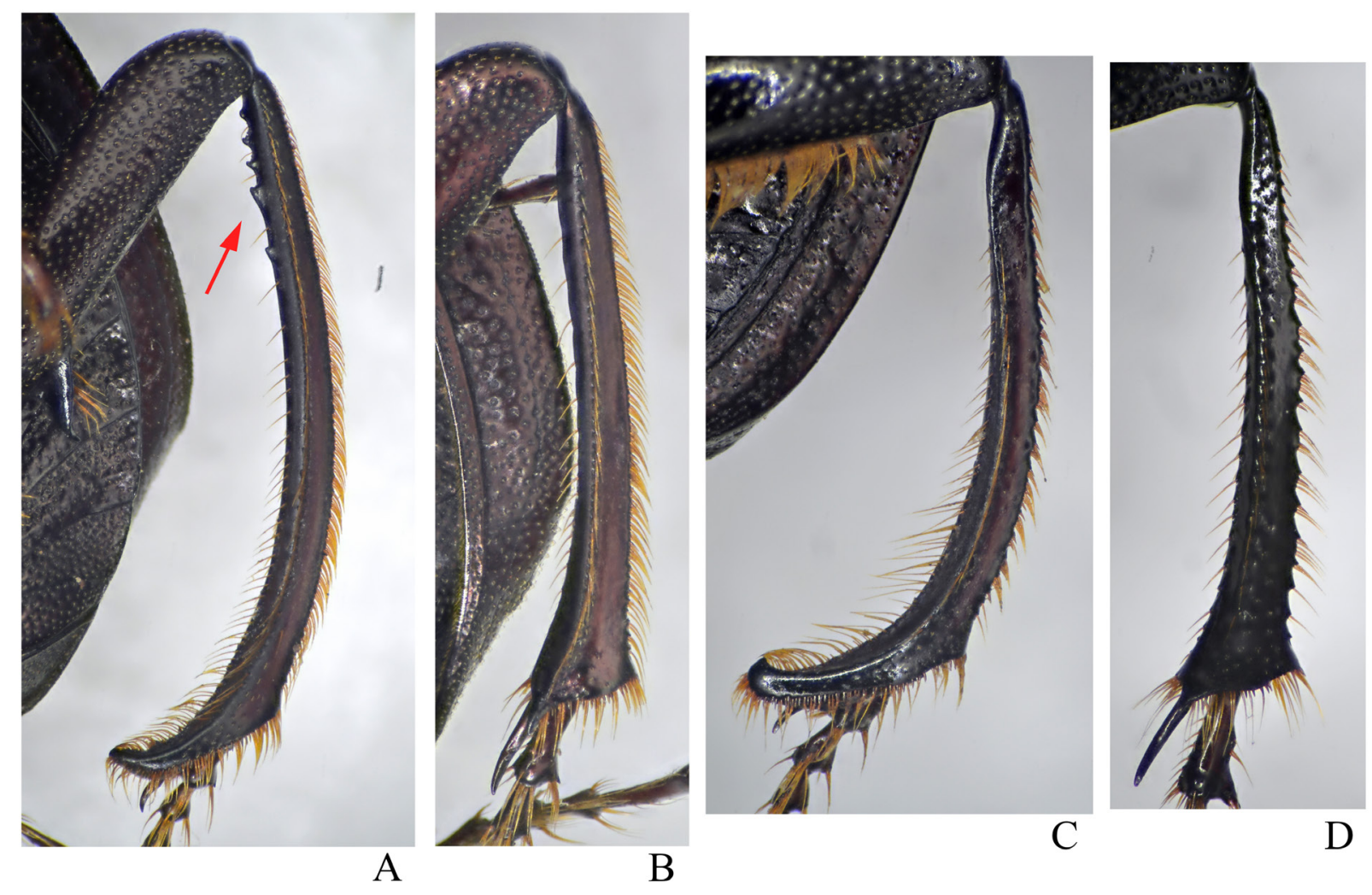

A
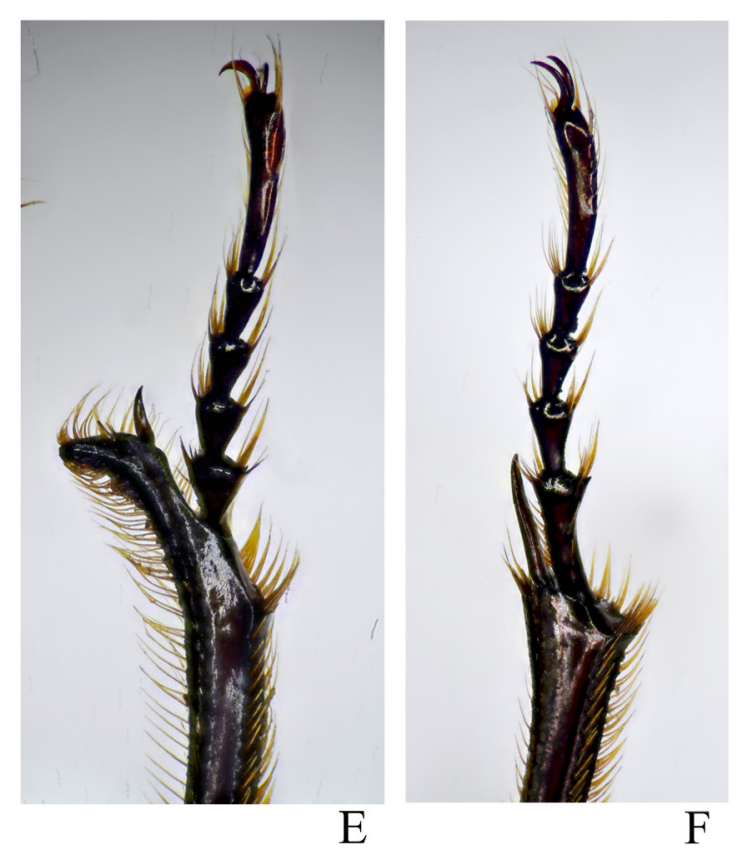

Fig. 20. Posterior legs. A-D. Metatibiae. A-B. Streblopus opatroides van Lansberge, 1874. A. O. B. . . C-D. S. punctatus (Balthasar, 1938). C. O. D. q. Note the strong sexual dimorphism and the many differences between the species. E-F. Metatarsi and apex of metatibia of S. opatroides. E. O. F. + . Observe how much shorter the male metatibial spur is in comparison to that of the female. 


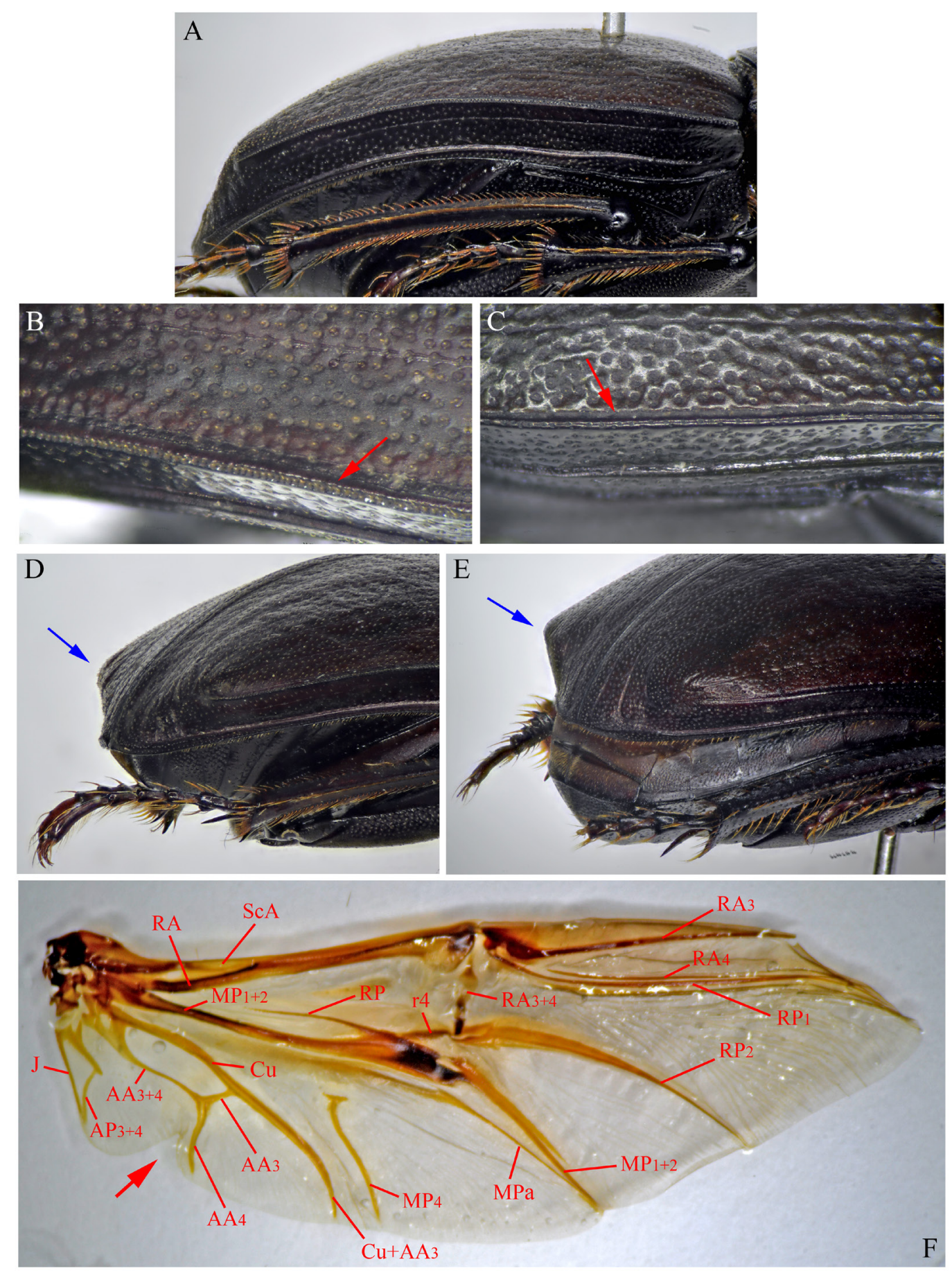

Fig. 21. Wings. A-E. Elytra. A. Lateral view of elytra of Streblopus opatroides van Lansberge, 1874. Note the very wide pseudepiplera and narrow epipleura. B-C. Pseudepipleural carina (indicated by red arrows). B. S. opatroides. C. S. punctatus (Balthasar, 1938). Observe that the pseudepipleural carina in $\mathrm{B}$ is completely interrupted by umbilicate punctures, whereas the pseudepipleural carina in $\mathrm{C}$ is almost completely smooth, with very tiny and isolated punctures. D-E. Lateral view of apex of elytra. D. S. opatroides. E. S. punctatus. Note how the distal calluses (shown by blue arrows) of S. punctatus are much more strongly projecting than those of S. opatroides. F. Right hind wing of Streblopus opatroides. Red arrow shows the notch of the anal fold. Abbreviations: $\mathrm{AA}=$ anal anterior; $\mathrm{AP}=$ anal posterior; $\mathrm{Cu}=$ cubitus; $\mathrm{J}=$ jugal; $\mathrm{MP}=$ media posterior; $\mathrm{MPa}=$ accessory MP; $\mathrm{r}_{4}=$ cross-vein $\mathrm{r}_{4}$ (cross-vein connecting veins $\mathrm{RA}_{3+4}$ and $\mathrm{RP}_{2}$ ); $\mathrm{RA}=$ radius anterior; $\mathrm{RP}=$ radius posterior; $\mathrm{ScA}=$ subcosta anterior. 
discussed the sexual dimorphism of the species (and it is worth noting that, based on his description, he correctly differentiated the sexes). Indeed, a second syntype was found by MC in the RBINS originating from the J. Thomson collection, whose Scarabaeoidea were incorporated into the RBINS in 1878 (Horn et al. 1990b). Notwithstanding our ignorance as to the whereabouts of the other syntypes, we decided to designate the only male syntype known to us, the MNHN specimen, as the lectotype of $S$. opatroides. We could recognize these two specimens as part of the type series because they both bear identification labels clearly handwritten by Van Lansberge (see examples of Van Lansberge's handwriting in Horn et al. 1990b). However, it is interesting to note that the lectotype came to the MNHN not via the Van Lansberge collection, but rather the Edgar von Harold and R. Oberthür collections, meaning that Harold probably received this specimen directly from Van Lansberge after the latter's studies for the description of the species.

The BMNH specimen from Espírito Santo was collected by the 19th-century French naturalist JeanThéodore Descourtilz (1796-1855), who from 1829 until his death lived in southeastern Brazil and travelled extensively, particularly in search of birds, across that region (Sick 1997). Before arriving at the BMNH, that specimen belonged to the collection of Alexander Fry (1821-1905), who lived and worked in Rio de Janeiro until 1854 (Max Barclay, pers. comm. to MC, Sep. 2019) and developed his Coleoptera collection largely by purchasing specimens. Therefore, it is not difficult to imagine that Fry bought his specimen of $S$. opatroides directly from Descourtilz while they were both living in the same region or through some intermediate. Be it as it may, the Fry collection was eventually bequeathed to
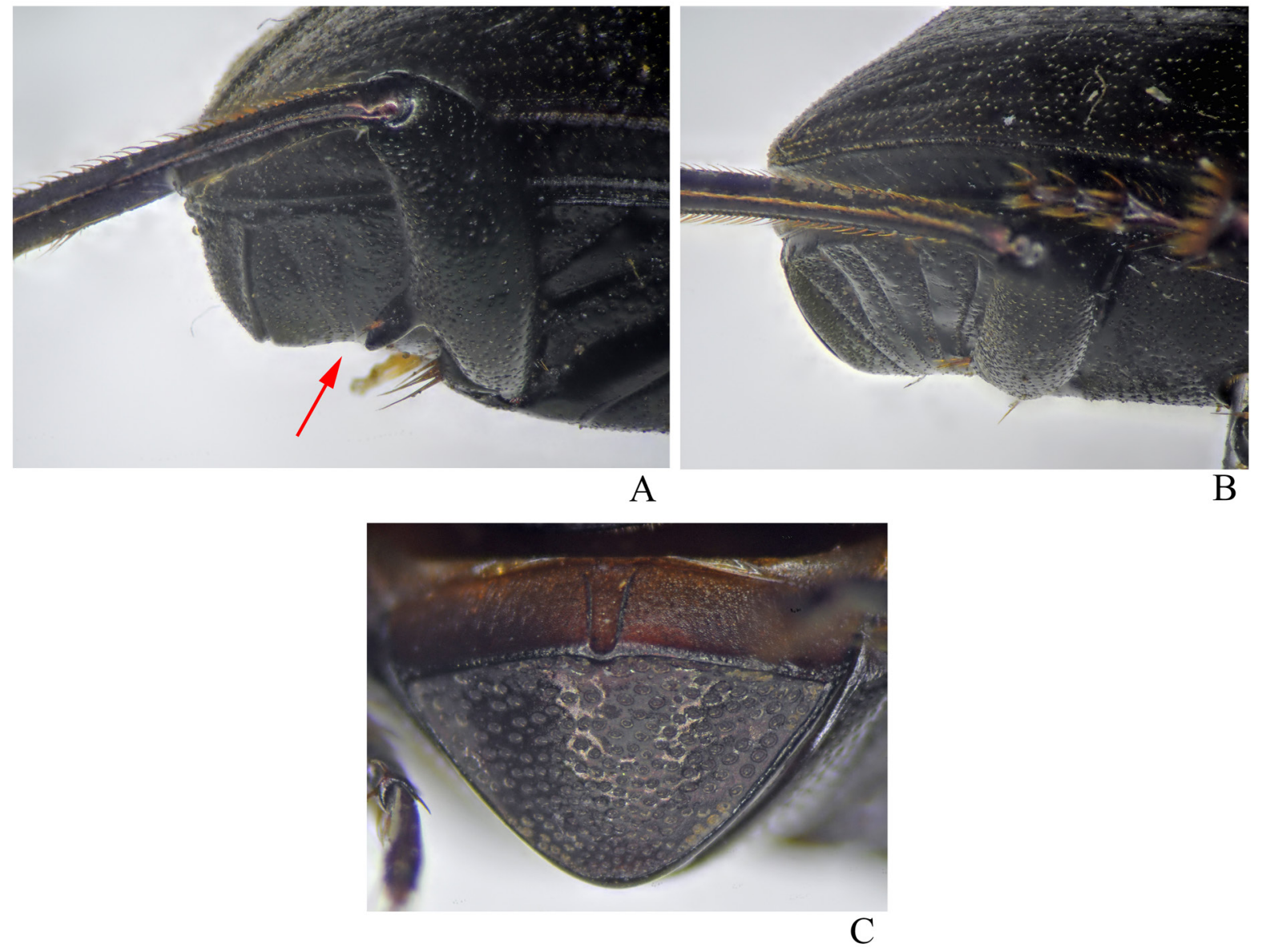

Fig. 22. Abdomen of Streblopus opatroides van Lansberge, 1874. A-B. Lateral view. A. ô. B. ๆ. Note that the female abdomen has a straighter surface than that of the male, which is concave (red arrow shows this concavity). C. Pygidium and prepygidium. 
the BMNH (Horn et al. 1990a) and that is why the Descourtilz specimen is housed there. What makes this specimen unique is that not even the old beetle collection of the MNRJ, the institution for which Descourtilz worked as a travelling naturalist for a brief period between 1854 and 1855 (Sick 1997), housed specimens collected by him (MC, pers. obs. between 2009 and 2017).

\section{Ecology}

As stated above for the genus, almost nothing is known about the behaviour of $S$. opatroides. Indeed, until the 1990s only six specimens were known apart from the syntypes, one third of them with erroneous provenance data (an MNHN male and the NMPC male), another third without locality content (the MNHN female and Harold's MNHN "Colonychus" specimen), and the final third with fairly general information ("Bahia" for the MZSP male and "Espírito Santo" for the BMNH female). The specimens collected over the past three decades, however, have shown that $S$. opatroides is a coprophagous species attracted to human faeces used as bait in pitfall traps and that lives in patches of lowland forests (recorded from 10 up to $800 \mathrm{~m}$ a.s.1.) across a limited range along the Brazilian states of Bahia and Espírito Santo (Fig. 4). Adults of the species seem to be active throughout the year, since specimens have been collected in every month except August, October and December. As discussed above, S. opatroides is probably a nocturnal forager, judging from the morphology of its eyes (with a very wide dorsal portion) and its dull dorsal colouration; indeed, Audino et al. (2014) recorded the species as nocturnal in their surveys. The data obtained by the latter authors also show that $S$. streblopus can be relatively abundant in mature forests (particularly primary forests, but also present in old secondary ones), but is absent from more disturbed environments such as mid- and early-succession stage forests and pastures. Nothing more is known about the natural history of $S$. opatroides.

Streblopus punctatus (Balthasar, 1938)

Figs 3-4, 5C-D, F, 6B, 7B, 8C-D, 12B, 13E-F, 14C-D, 15C-D, G-H, 16B-C, 17C-F, 18C-D, 19D-E, 20C-D, 21C, E, 23E-H, 25, 26B, 27B-D, 28

Streblopoides punctatus Balthasar, 1938: 216.

Streblopoides punctatus - Balthasar 1941: 346; 1951: 331. — Vulcano \& Pereira 1964: 580-581. — Bezděk \& Hájek 2011: 374.

Streblopoides punctata - Blackwelder 1944: 203.

Streblopoides? punctatus - Krajcik 2006: 163.

Streblopus punctatus - Halffter \& Martínez 1966: 153-154, 157-158, 162-165, figs 18-21. - Horgan

2005a: 131; 2005b: 609-610; 2006: 364; 2009: 3529, 3538. — Bezděk \& Hájek 2011: 374. —

Carvajal-López et al. 2011: 316. - Carvajal-López 2012: 195-197, 199, figs 1-2. — Krajcik 2012:

249. - Ratcliffe et al. 2015: 196. — Chamorro et al. 2018: 85, 98, fig. 8c; 2019: 234-235, 313, fig.

50d. - Cupello \& Vaz-de-Mello 2019: 168-169.

Streblopus opatroides (error) - Paulian 1939: 27 (in part: specimen from Oxapampa, Peru).

\section{Material examined}

\section{Holotype}

PERU? • + ; dubious provenance [label indicates Peru, Piura, Huancabamba, $3000 \mathrm{~m}$ a.s.l., but this does not seem to be precise; see comments below] ("punctatus / m." [Balthasar's handwriting], "genotyp / stv. [?] punctatus / n. sp. / Dr. V. Balthasar det." [Balthasar's handwriting], "TYPUS", "Huancabamba / N.Peru, 3000 m / H. Rolle.", "HOLOTYPE + / Streblopoides punctatus / Balthasar, 1938 / Labelled by Cupello, 2019” [MC's handwriting] ); NMPC.

Other material $(24 \hat{\partial} \hat{\partial}, 16 q+q)$

ECUADOR - Zamora-Chinchipe 1 त, 1 क; Refugio de Vida Silvestre El Zarza, Campamento Las Peñas, "Parcela 5"; 1536 m a.s.1.; 9 Sep. 2012; William Chamorro leg.; pitfall baited with human faeces; 
CUPELLO M. et al., Systematics of Streblopus and dung beetle biogeography

CEMT -1 ( Silvestre E1 Zarza, Campamento Las Peñas (“C. Las Peñas"), "via a P4”; 1533 m a.s.1.; 11 Sep. 2011; William Chamorro leg.; pitfall baited with human faeces; CEMT $\bullet 1 \lesssim$ (genitalia dissected), 1 \& (left posterior wing and genitalia dissected); Yantzaza; $1433 \mathrm{~m}$ a.s.1.; 11 Dec. 2010; T. Ghia leg.; pitfall baited with human faeces; CEMT.

PERU - Cuzco - 1 đ; La Convención, Echarate, Comunidad Campesina Santa Rosa ("CC. Santa Rosa"); 12 $2^{\circ} 33^{\prime} 54.41^{\prime \prime} \mathrm{S}, 7^{\circ} 05^{\prime} 36.85^{\prime \prime} \mathrm{W} ; 1747 \mathrm{~m}$ a.s.1.; 26-29 Jan. 2010; C. Carranza and C. Rossi

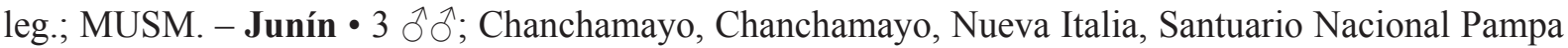
Hermosa; $10^{\circ} 59^{\prime} 52.7^{\prime \prime}$ S, 75²5'34.4" W; 1737 m a.s.1.; 30 May 2011; D. Silva leg.; MUSM • 1 ๙ (genitalia dissected); same collection data as for preceding; ex W.D. Edmonds collection; TAMU • $2 \partial^{\lambda}$; Chanchamayo, Chanchamayo, Nueva Italia, Santuario Nacional Pampa Hermosa; $10^{\circ} 59^{\prime} 51.8^{\prime \prime} \mathrm{S}$, 75²5'35.9" W; $1879 \mathrm{~m}$ a.s.1.; 30 May 2011; D. Silva leg.; MUSM • 1 \%; same collection data as for preceding; ex W.D. Edmonds collection; TAMU - 1 \& (genitalia dissected); Chanchamayo, Chanchamayo, Nueva Italia, Santuario Nacional Pampa Hermosa; $10^{\circ} 59^{\prime} 51.8^{\prime \prime}$ S, 75²5'35.9" W; 1940 m a.s.1.; 23-31 May [201?]; M. Alvarado leg.; Podocarpus forest; MUSM • 1 क; Chanchamayo, San Ramón; $11^{\circ} 10^{\prime} \mathrm{S}, 75^{\circ} 18^{\prime} \mathrm{W}$; $1500 \mathrm{~m}$ a.s.1.; 25 Aug. 2002; F.G. Horgan leg.; forest; pitfall with human

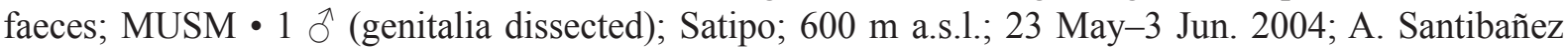
leg.; CEMT • 1 ठิ (genitalia dissected), 1 \& (genitalia dissected); Satipo; 1100 m a.s.1.; Dec. 2004; A. Santibañez leg.; CEMT • 1 q ; Satipo; 1100 m a.s.l.; Dec. 2004; A. Santibañez leg.; MNHN • 1 ㅇ

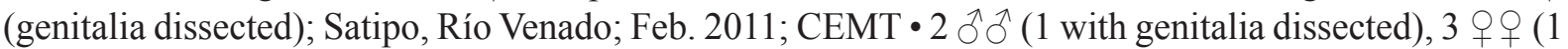
with genitalia dissected); Satipo, "near [city of] Satipo"; > 1000 m a.s.1.; Dec. 2004; A. Santibañez leg.; yungas; trap with human faeces; ex W.D. Edmonds collection; TAMU. - Pasco $\bullet 2$ ô $\widehat{\text { ते }}(1$ with genitalia dissected), 1 P; Oxapampa, Villa Rica, Bosque de Protección de San Matías-San Carlos; 10³8'51" S, $75^{\circ} 12^{\prime} 22^{\prime \prime}$ W; 1556 m a.s.1.; 3-5 May 2012; L. Figueroa and V. Borda leg.; pitfall with dung; MUSM •

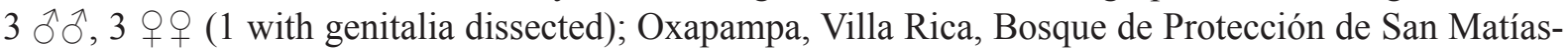

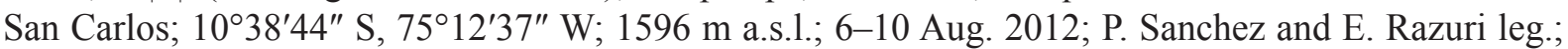
MUSM • 1 đ'; Oxapampa, Villa Rica, Bosque de Protección de San Matías-San Carlos; 10³6'27" S, $75^{\circ} 12^{\prime} 18^{\prime \prime}$ W; 1627 m a.s.1.; 3-5 May 2012; L. Figueroa and V. Borda leg.; pitfall with dung; MUSM • $4 \widehat{\partial} \widehat{\partial}$ (1 with genitalia dissected), 1 O ; Oxapampa, Villa Rica, Bosque de Protección de San Matías-San

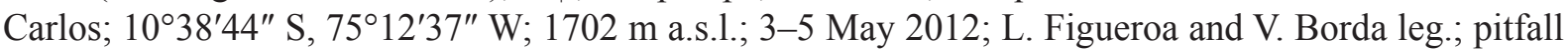
with dung; MUSM.

\section{Erroneous record}

PERU • 1 + ; Lima; Sep. 1949; ex Martínez collection; CMNC.

Not studied (label information provided by François Génier (CMNC); 2 우)

PERU • 1 क; Huánuco, Leoncio Prado, La Divisoria (“Divisoria”); 1300 m a.s.1.; Aug. 1974; Bordon leg.; ex Martínez collection; CMNC.

\section{Etymology}

Derived from the Latin word for punctate (Brown 1956), a probable reference to the fine umbilicate punctation seen on the pronotum of this species.

\section{Redescription}

Measurements. Males (4 spec.): TL: AV 13.53, MX 14.4, MN 12.45. EW: AV 8.08, MX 8.64, MN 7.04. PW: AV 7.23, MX 8.06, MN 6.51. - Females (5 spec.): TL: AV 12.96, MX 13.95, MN 12.6. EW: AV 7.71, MX 8.0, MN 7.52. PW: AV 6.88, MX 7.13, MN 6.66.

Colouration. Antennal club usually with dark tegument and yellowish pubescence; some individuals with lighter tegument. Dorsum light brown; venter, including legs, dark brown to almost black. Some 

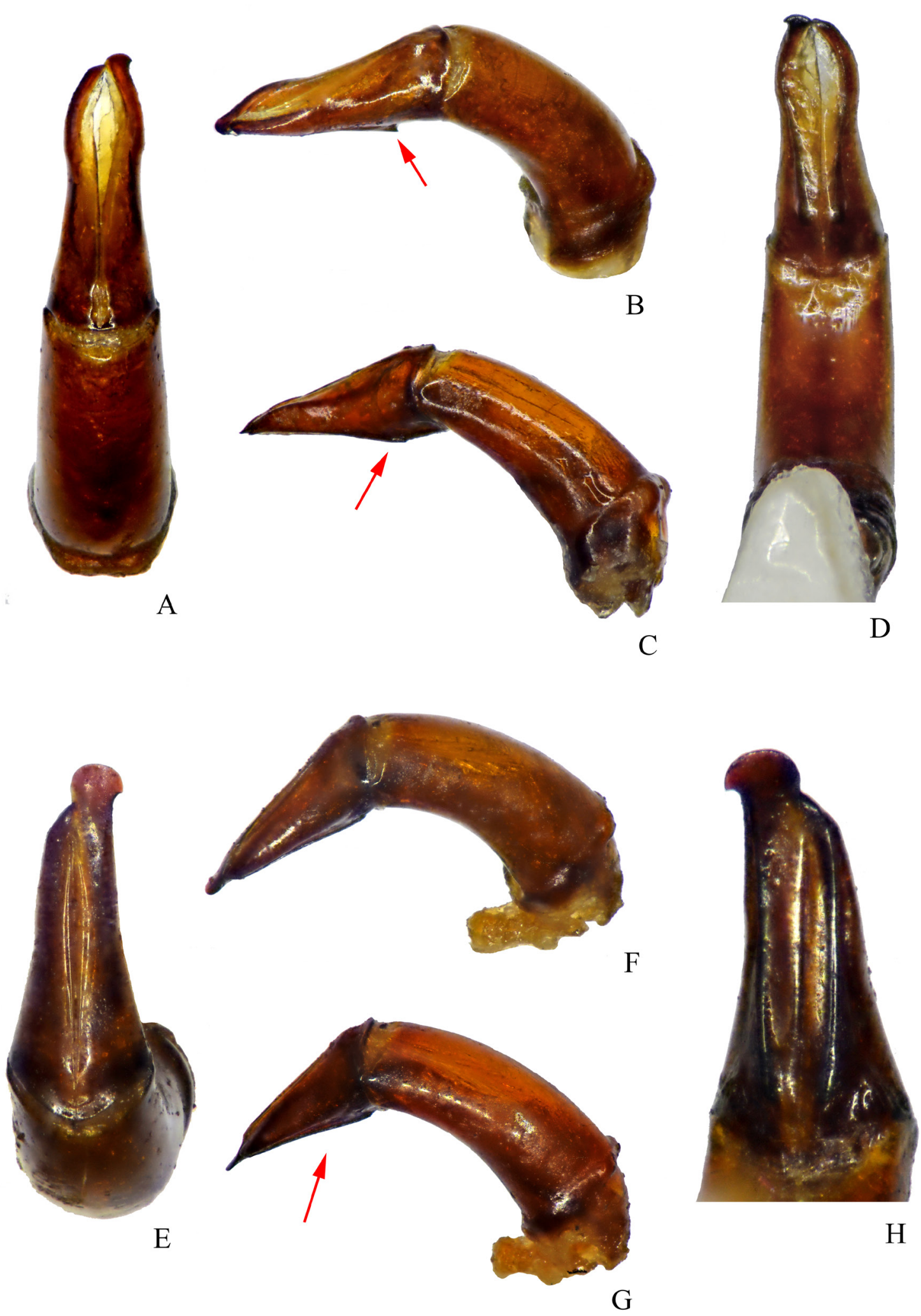

Fig. 23. Genital capsule. A-D. Streblopus opatroides van Lansberge, 1874. A. Dorsal view. B-C. Lateral view from slightly different angles (red arrow shows the ventral surface and its keel). D. Ventral view. E-H. S. punctatus. (Balthasar, 1938). E. Dorsal view. F-G. Lateral view from slightly different angles (red arrow indicates ventral surface). H. Ventral view. Observe the differences in the shape of the parameres, in particular how the apical hook is much more prominent in S. punctatus. 
parts of body, especially elytra, pygidium and outer sides of metaventrite, sometimes with silky reddish sheen.

HeAD. Canthus short, with short penetration into eyes (Fig. 5F). Clypeal process a transverse carina, acuminate at apex (Fig. 6C). Antennae with 8 articles; first visible article of funicle little longer than combined length of second and third visible articles of funicle combined (Fig. 7B). Labrum with anterolateral regions not well projected and with external margin more or less straight; anterior labral margin not broad; epipharynx with short medial brush and median area almost entirely covered by dense, thick socketed setae (Fig. 8C-D).
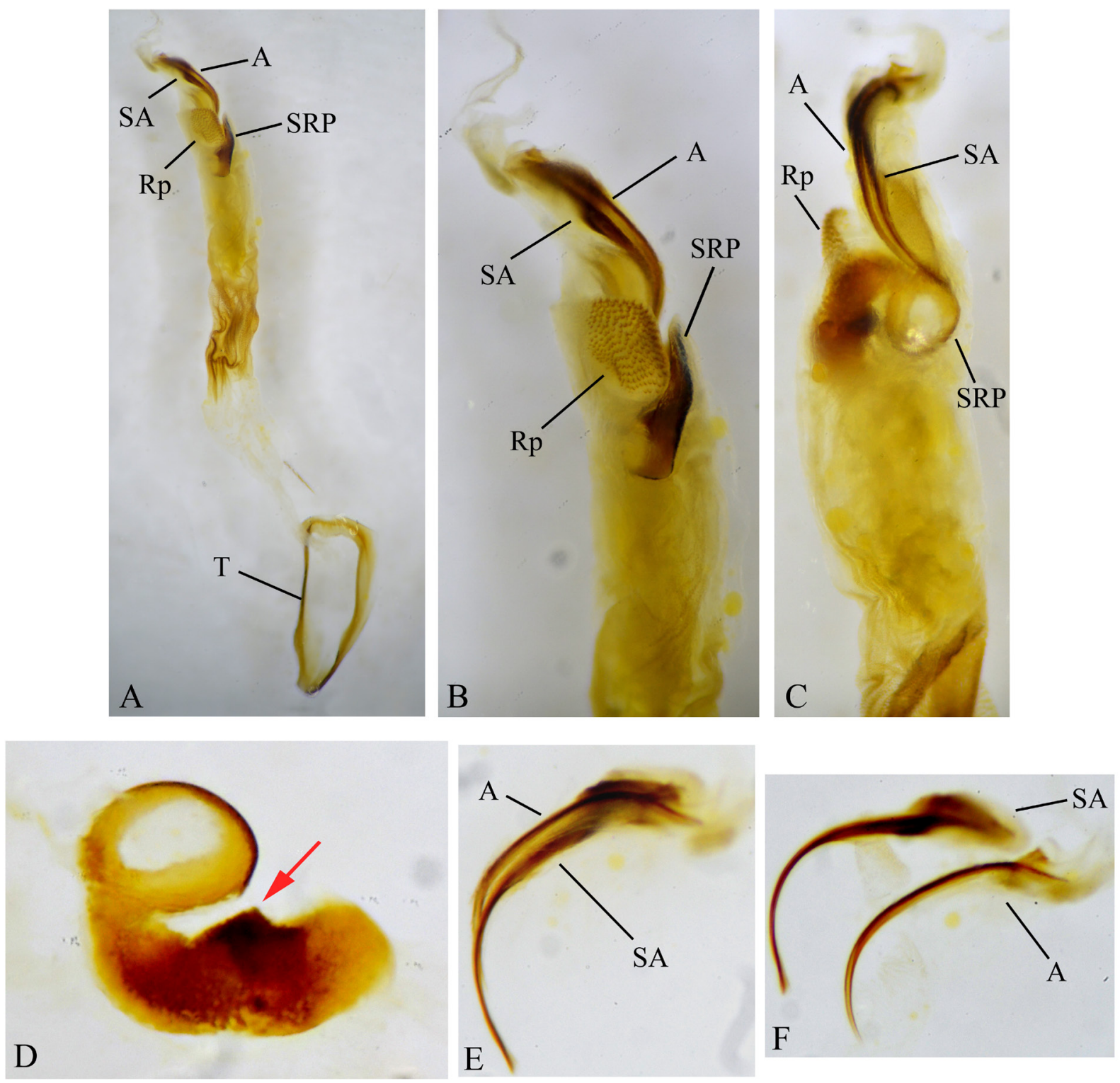

Fig. 24. Internal sac of Streblopus opatroides van Lansberge, 1874. A-C. Different views of the undissected internal sac and sclerites in resting position. D. Superior right peripheral sclerite. Arrow indicates a triangular area of a more sclerotized tegument that is probably homologous to a similar triangular area on the SRP of S. punctatus (Balthasar, 1938). E-F. Apical and subapical sclerites. E. Resting position. F. Sclerites after separation. Abbreviations: $A=$ axial sclerite; $\mathrm{Rp}=$ raspule; $\mathrm{SA}=$ subaxial sclerite; $\mathrm{SRP}=$ superior right peripheral sclerite; $\mathrm{T}=$ temones. 
THORAx. Pronotum with sparse umbilicate punctation at centre (approximately at area between eyes) (Fig. 12B); towards sides and posterior region, punctation progressively denser, but punctures never confluent; tegument between punctures with diffuse microsculpture. Prosternum, mesoventrite, mesanepisterna, metanepisterna and metaventrite entirely covered by sparse umbilicate punctation, particularly sparse and with smaller punctures on anterior lobe and posterior region of metaventrite; tegument between punctures lustrous, with extremely diffuse microsculpture (Fig. 13E-F).

LeGs. Trochantofemoral articulation not produced into spur in either sex. Mesocoxae with few sparse umbilicate punctures and tegument lustrous, covered by diffuse microsculpture. Mesofemora always

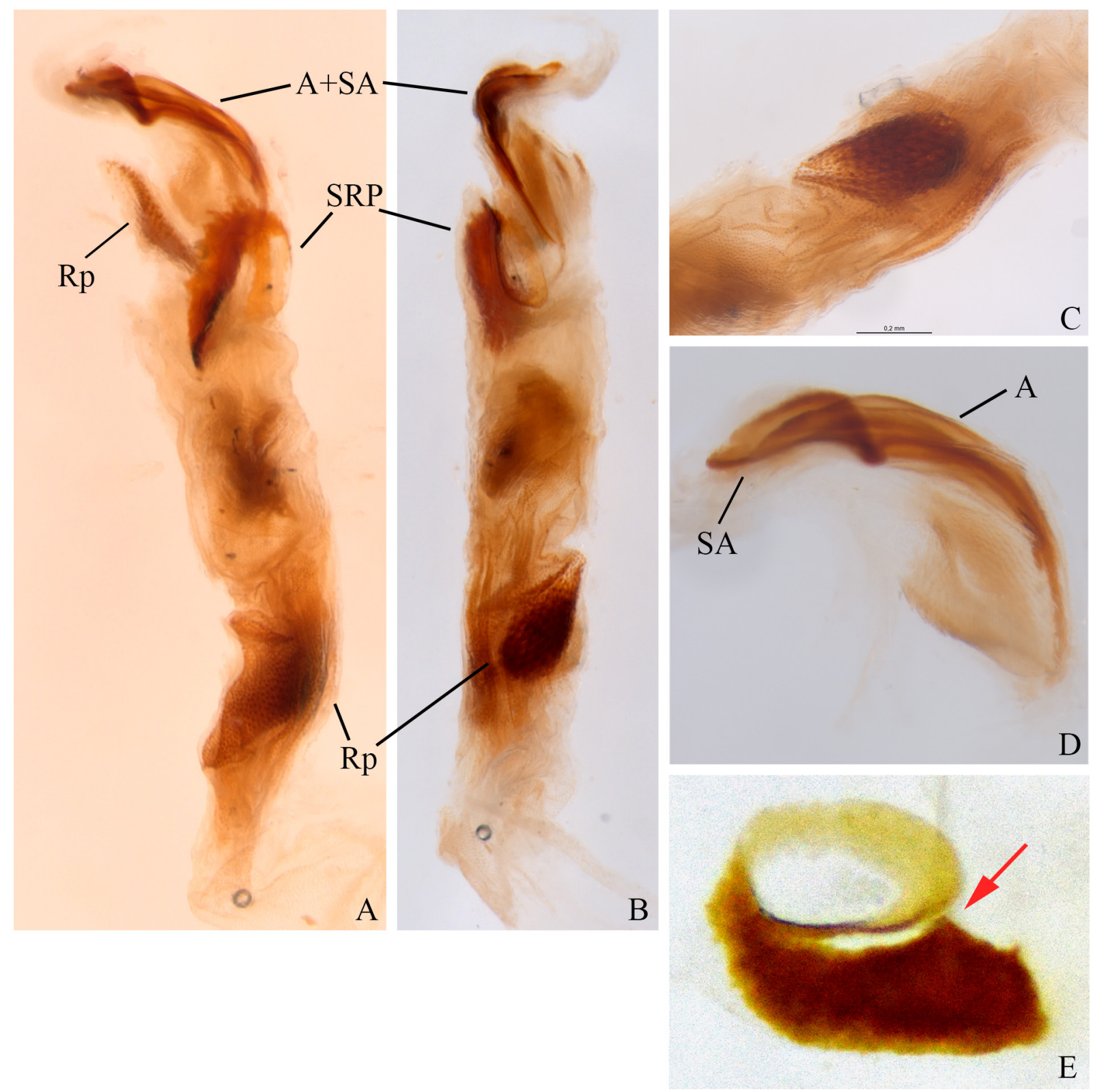

Fig. 25. Internal sac of Streblopus punctatus (Balthasar, 1938). A-B. General aspect before dissection. C. Raspule. D. Apical and subapical sclerites. E. Superior right peripheral sclerite. Arrow indicates a triangular area of a more sclerotized tegument that is probably homologous to a similar triangular area on the SRP of $S$. opatroides van Lansberge, 1874. Abbreviations: A = axial sclerite; $\mathrm{Rp}=$ raspule; $\mathrm{SA}=$ subaxial sclerite; $\mathrm{SRP}=$ superior right peripheral sclerite; $\mathrm{T}=$ temones. 
glabrous on posterior edge of both sexes (Fig. 17C-F; sometimes with a few isolated setae in males); ventral surface covered by small and sparse umbilicate punctures at base and centre, and larger and denser punctures near apex and posterior edge; tegument between punctures lustrous and with extremely diffuse microsculpture, except near posterior edge, which is sexually dimorphic (see below). Mesotibiae with internal edge with a few erect setae, never forming well-defined longitudinal rows in either sex (Fig. 18C-D). Metafemora with sexually dimorphic brush of long setae on posterior edge (see below) (Fig. 19D-E). Metatibiae with ventral surface without umbilicate punctures (Ecuadorian specimens) or with at least some umbilicate punctures along entire tegument (Peruvian specimens); internal edge smooth, without row of sharp teeth at base in both sexes (Fig. 20C-D).

ElYTRA. Striae very fine and sometimes discontinuous, especially those on pseudepipleura and stria VII on disc. Tegument covered by small umbilicate punctures, each puncture glabrous or with short central seta; tegument between punctures with diffuse microsculpture (alveoli sometimes better delimited towards apices). Lateral carina (pseudepipleural carina) smooth, not interrupted by row of umbilicate punctures (Fig. 21C). Apices of elytra strongly deflected downwards; distal calluses strongly projecting (Fig. 21E).

Terminalia. Aedeagus: Right paramere with pronounced, broadly rounded apical projection with clear external spine (Fig. 23E-H); in dorsal view, parameres with external edges more or less straight (Fig. 23E); in lateral view, ventral side straight, with no week keel nor inclination (Fig. 23F-G). Internal sac with axial and subaxial sclerites distinct in shape: subaxial sclerite curved apically and surrounding axial sclerite, which is simply curved and shorter than subaxial sclerite (Fig. 25D). - Genital sclerite: Medial sclerotized plate (MSP) well sclerotized and with lateral arches more or less straight, not concave; posterior arms of MSP well developed and separated from one another by a deep 'U-shaped' emargination (Fig. 26B). - Spermatheca: Entirely slender and with a pair of apical hooks (Fig. 27B-C).
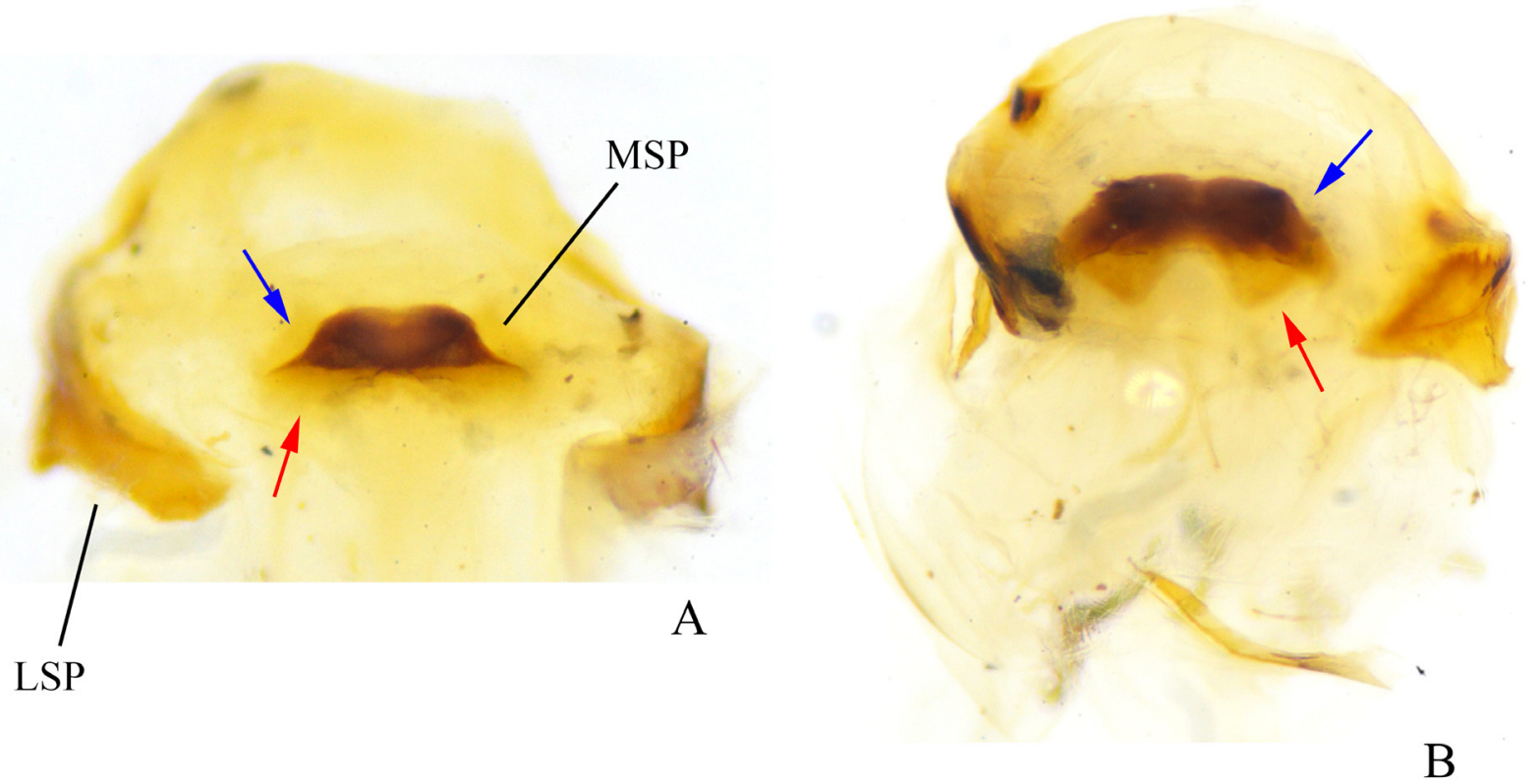

Fig. 26. Genital segment. A. Streblopus opatroides van Lansberge, 1874. B. S. punctatus (Balthasar, 1938). Note that the medial sclerotized plate is larger and more sclerotized in S. punctatus than in S. opatroides; other differences refer to their lateral arches (indicated by blue arrows), which are concave in S. opatroides and more or less straight in S. punctatus, and the posterior arms of the MSP (indicated by red arrows), which are well developed and separated by a deep 'U-shape' in $S$. punctatus and only slightly indicated in $S$. opatroides. Abbreviations: LSP = lateral sclerotized plate; MSP = medial sclerotized plate. 
SeXual Dimorphism. Male: Clypeus slightly emarginated at apex (Fig. 5C). Metaventrite with excavation on posterior region slightly wider and deeper in males than in females (Fig. 13E). Profemora with anterior margin raised into a single spur (Fig. 14C). Protibiae as described above for genus; protibial spur very short, bent inwardly, acuminate (Figs 15C, G, 16C). Mesofemora near posterior edge with tegument covered by large umbilicate punctures surrounded by dense alveolar microsculpture

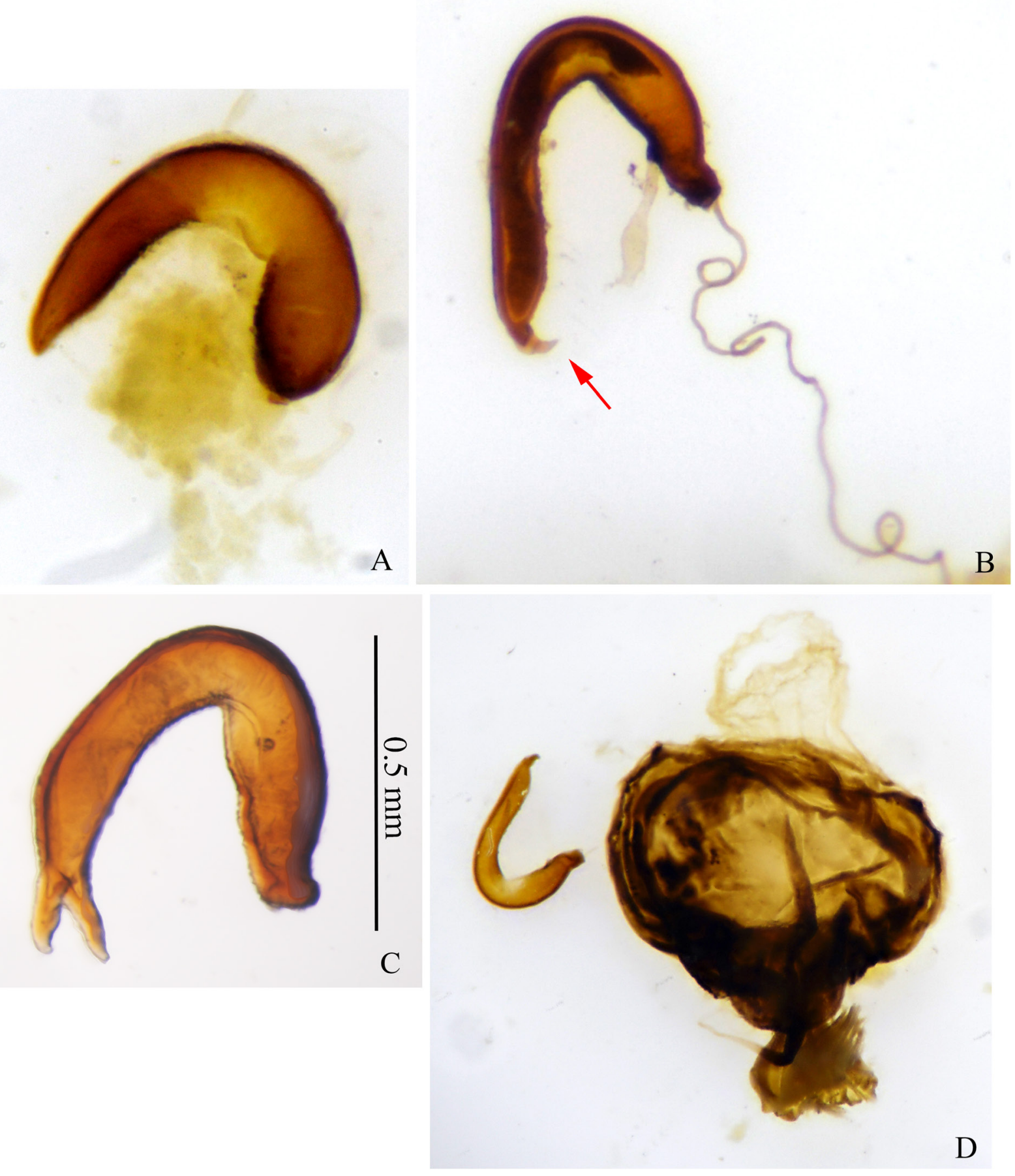

Fig. 27. Female genitalia. A-C. Spermatheca. A. Streblopus opatroides van Lansberge, 1874. B-C. S. punctatus (Balthasar, 1938) (slightly different views). Observe that the spermatheca of the latter species is more slender and has a unique pair of apical hooks (red arrow). D. General view of the entire female genitalia of $S$. punctatus. 
CUPELLO M. et al., Systematics of Streblopus and dung beetle biogeography

(Fig. 17C, E). Metafemora with brush of long setae covering basal two-thirds of posterior edge; posterior edge not crenulate and with small spur bent inwards rising just after trochanter (Fig. 19D). - Female: Clypeus with apical emargination absent or only slightly marked (Fig. 5D). Metaventrite with excavation on posterior region slightly narrower and shallower in females than in males (Fig. 13F). Profemora with anterior margin simple, not raised into spur (Fig. 14D). Protibiae with two apical teeth subequal in length, contiguous at base and apart from basal tooth (Fig. 15D, H); all three lateral teeth (especially two apical ones) more or less directed forwards (Fig. 15D, H); protibial spur bent inwards apically, never bifurcated (Fig. 15D, H). Mesofemora near posterior edge with tegument covered by dense umbilicate punctation and tegument between punctures almost smooth, with very diffuse microsculpture (as rest of tegument of mesofemora) (Fig. 17D, F). Metafemora with brush of sparse, long setae covering approximately basal two-thirds of posterior edge; posterior edge crenulate along brush of setae and devoid of any spur (Fig. 19E).

\section{Distribution}

Sub-Andean areas in the Peruvian and Ecuadorian Yungas (Fig. 4).

Ecoregions. Eastern Cordillera Real Montane Forest and Peruvian Yungas.

Collection sites. Ecuador - Zamora Chinchipe: Cordillera del Cóndor (Sector Colibrí), Refugio de Vida Silvestre 'El Zarza', Yantzaza. Peru - Huánuco: Leoncio Prado (La Divisoria); Pasco: Oxapampa (Villa Rica: Bosque de Protección de San Matías-San Carlos); Junín: Chanchamayo (Nueva Italia: Santuario Nacional Pampa Hermosa; San Ramón), Satipo (Satipo); Cuzco: La Convención (Echarate).

\section{Intraspecific variation}

Until fairly recently, only two specimens of $S$. punctatus were known to entomologists, the holotype female housed in the NMPC and another female deposited in the MNHN, both collected in Peru. Over the past two decades, however, with the growing interest for dung beetle studies among South American scholars and the subsequent increase in the number of collections in regions hitherto unexplored in terms of their scarabaeine fauna, that number has risen significantly. For this paper, we were able to examine 43 specimens ( 24 males and 19 females, including the holotype) deposited in five museums, but we know that some additional individuals are housed in at least two other collections in Ecuador (the Escuela Politécnica Nacional, Quito, and the Museo de Zoología de la Universidad Técnica Particular de Loja, Loja; Carvajal-López 2012; Chamorro et al. 2019). While still not a huge sample, these specimens reveal that $S$. punctatus shows some noticeable morphological variation, one of them being clearly geographical.

Firstly, two individuals, a Peruvian male and an Ecuadorian female, possess an antennal club with the tegument considerably lighter than on the other specimens examined, therefore departing from the typical dark tegument of $S$. punctatus and approaching the pattern observed in S. opatroides, whose antennal club has a yellowish tegument. A more significant variation, however, concerns the metatibial punctation: while all Ecuadorian individuals examined show the ventral surface of the metatibiae to be devoid of umbilicate punctures, all the Peruvian specimens studied by us, including the holotype, have at least some sparse umbilicate punctures along their entire ventral surface. However, since all the Peruvian individuals we had the chance to see came from much further south in Peru than its border with Ecuador, we cannot tell exactly how one form replaces the other over the distribution of S. punctatus, i.e., whether the transition between them is smooth or abrupt. Unfortunately, Carvajal-López (2012), who redescribed S. punctatus based on a female collected in the Cordillera del Cóndor, on the border between Ecuador and Peru, did not comment on what the tegument of the metatibiae of his specimen was like. As mentioned above for the colour variation observed in S. opatroides, future collections will give us more detail on how this variation occurs in nature and whether intermediate populations show 
intergradation between the two forms seen here. As for many other characters showing geographical variation in dung beetle species, nothing is known about the functional role of the umbilicate punctures of the metatibiae in this species, although it is reasonable to suppose they perform some kind of tactile or chemical function. Why this should vary geographically, however, remains totally unknown.

A final variation observed among the specimens is clearly non-genetic: two Peruvian males lack the protibial spur, but it is evident that this condition is due to wear, because one of them has a very short indication of a right spur, which is clearly reduced due to abrasion. As will be discussed on the following pages, in S. opatroides the protibial spur is never expressed in males, being restricted to females in that species.

\section{Remarks}

The information on the presence of S. punctatus in Cordillera del Cóndor (Zamora Chinchipe, Ecuador) is based on Carvajal-López (2012), who collected a female at $1446 \mathrm{~m}$ a.s.l. in that mountain range using a pitfall trap. Conversely, we question two other geographical records present in the literature. First, the type locality mentioned by Balthasar (1938) and indeed stated on the holotype's label - namely, some place at about $3000 \mathrm{~m}$ a.s.l. in the province of Huancabamba (Piura, Peru) - is probably incorrect, since no other specimens are know to have been collected either above $\sim 1950 \mathrm{~m}$ a.s.l. or in the Páramo ecosystem. Likewise, the record in Halffter \& Martínez (1966) of S. punctatus from the outskirts of Lima ("arredores de Lima") is also most probably erroneous, since no other individuals are known from the west side of the Andes nor from the Sechura Desert ecoregion. Luis Figueroa (pers. comm. to MC, 23 Sep. 2018), the Coleoptera curator at the MUSM and specialist in Peruvian dung beetles, agrees that both records are inaccurate.

\section{Ecology}

Like its congeneric $S$. opatroides, almost nothing is known about the biology of $S$. punctatus. The specimens studied here were collected in both forest fragments and continuous forests at altitudes between 600 and $1940 \mathrm{~m}$, and the holotype is labelled as having been collected at $3000 \mathrm{~m}$ (but see comments above about the accuracy of this record). The species is attracted to pitfall traps baited with human and pig excrement (Horgan 2005a, 2005b, 2006, 2009; Carvajal-López 2012; Chamorro et al. 2019; data from specimen labels), and adults, like those of S. opatroides, seem to be active throughout the year, having been recorded in the period "May-June" and all individual months from August to February (Carvajal-López 2012; Chamorro et al. 2019; data from specimen labels). Horgan's classification of S. punctatus as a roller (Horgan 2005a) was probably based on inference from its morphology, not on actual observations of the food relocation behaviour of this species. Finally, as discussed above for S. opatroides, the wide eyes and dull colouration of this species lead us to hypothesize that flight activity in S. punctatus is nocturnal.

\section{Discussion}

Two main groups of questions have been raised about the evolutionary history of Streblopus: first, how many species are there in the genus, and, if more than one, how can we differentiate them? Second, what is the phylogenetic placement of Streblopus in the dung beetle tree of life, and what was the geographical origin of the genus? In the following sections, we address these two issues based both on our new observations about the morphology and distribution of the genus and on a synthesis of these new observations with the information present in the literature.

\section{Species diversity in Streblopus}

Given the rarity of specimens of Streblopus in collections over the $20^{\text {th }}$ century, very little had been known about the diversity of the genus until now, both intra- and interspecifically. Indeed, Halffter \& 
Martínez (1966) even questioned whether the differences observed between the few specimens known at that time for $S$. opatroides and $S$. punctatus could be a simple case of sexual dimorphism, since they knew of only three males of the first putative species and two females of the second (two female $S$. opatroides were already housed in MNHN and BMNH during the 1960s, and the latter was even cited in Paulian's study of the genus (Paulian 1939), but Halffter \& Martínez (1966) did not examine them). In our study, we saw that while sexual dimorphism is indeed quite remarkable in Streblopus, most of the differences observed by Halffter \& Martínez (1966) between S. opatroides and S. punctatus are consistent with the hypothesis that they represent distinct species. In addition to the morphological differences is the disjunct distribution pattern of $S$. opatroides and S. punctatus, one occurring in the Atlantic Forest along a portion of the Brazilian coast, the other across sub-Andean evergreen forests in the Peruvian and Ecuadorian Amazonia. ${ }^{1}$

In the following sections, we discuss the main evidence indicating that both metapopulations indeed represent distinct species.

\section{Colouration}

Even at first glance, it is possible to note that the sub-Andean and the Atlantic Forest populations of Streblopus are quite distinct in terms of colouration. The sub-Andean ones show individuals distinctly darker, with dorsum light brown (Fig. 3A, C-D) and venter, including legs, dark brown or even almost entirely black; only occasionally may some parts of the body, such as the elytra, pygidium and the outer sides of the metaventrite, show some weak silky reddish sheen. In contrast, most of the populations in the Atlantic Forest show evident reddish and olivaceous dorsal reflections in the predominantly brown tegument (Fig. 1 A-C) and the venter has a strong reddish metallic sheen (Fig. 2). The exception in the Atlantic Forest are populations in some few localities in southeastern Bahia State, where individuals show an intermediate condition, in which the reddish and olivaceous dorsal reflections are usually absent and the venter is completely black (thus resembling the sub-Andean populations) (Fig. 2), whereas the dorsal colouration is never completely black (in which they are similar to the other populations in the Atlantic Forest).

\section{Eye canthus}

As first noted by Halffter \& Martínez (1966), the length of the eye canthus varies between the two metapopulations: while sub-Andean individuals have a rather short canthus that almost does not penetrate the eyes (Fig. 5B-C, E), Atlantic Forest specimens have a much longer canthus that, in lateral view, reaches the centre of the eyes (Fig. 5A-B, D). Nothing is known about the functional role of this structure in Streblopus.

\section{Clypeal process}

The differences between the clypeal process of the sub-Andean and Atlantic Forest metapopulations of Streblopus was first noted by Halffter \& Martínez (1966). While in the sub-Andean specimens the clypeal process is a transverse carina with acuminate apex (Fig. 6B), in the Atlantic Forest ones it has a rounded apex (Fig. 6A). Since nothing is known about the functional role of the clypeal process in dung beetles, we cannot speculate as to the ultimate causal factors that brought these distinct forms into existence. It is interesting to note, nevertheless, that other groups of Scarabaeinae, such as Dichotomiini

\footnotetext{
${ }^{1}$ In this paper, we adopt a broader definition for the Amazonian biome, including not only the lowland forests of the Amazon Basin, but also the high- and lowland forests of the Guiana Shield and, particularly important, the transitional montane cloud forests along the eastern slopes of the Andes (i.e., the "Yungas sensu lato"). In short, according to our interpretation, the Amazon biome includes all humid broadleaf forest habitats lying between the Andes and the South American Dry Diagonal. That is the reason why S. punctatus, which is endemic to the subAndean cloud forests, is here considered to be an Amazonian species.
} 
and Phanaeini, also have highly diverse clypeal processes in terms of morphology (see Edmonds 1972; Vaz-de-Mello et al. 2011).

\section{Antennae}

One of the most remarkable differences between the sub-Andean and the Atlantic Forest populations concerns the antennae. Firstly, the colouration of the antennal tegument is distinct between them, with the sub-Andean individuals having on average a much darker brown tegument on the antennal club (Fig. 7B), whereas the Atlantic Forest specimens show a yellowish tegument on that structure (Fig. 7A). In both metapopulations, however, the colour of the pubescence covering the antennal lamellae is the same, yellowish. However, the most striking difference in the antennae of these two metapopulations concerns the number of antennal articles: while sub-Andean populations have an apomorphic 8-articulated antenna, Atlantic Forest ones have a more generalized 9-articulated antenna. Halffter \& Martínez (1966) considered this the "most important" difference between S. opatroides and S. punctatus, and doubted the possibility of it being sexually dimorphic, in which they were right: both sexes in both metapopulations show the same number of antennal articles. But what is the exact nature of this difference? In other words, which are the articles involved in the reduction of total number of antennomeres?

Krell (1992) presented a rather complete discussion on the morphogenesis of the antennal articles in scarab beetles, and we base much of our discussion on his conclusions. During the development of the insect antenna, flagellomeres are added by subdivision of a single unarticulate structure (Matsuda 1965; Krell 1992; Minelli 2004, 2017) by a process called arthrogenesis (Krell 1992). As successive arthrogeneses divide a previously unarticulated portion of the developing antenna into two halves, if the expression of any particular arthrogenesis is suppressed, then the ancestral separation of two flagellomeres is lost and the area corresponding to those two flagellomeres in the ancestral form will be seen as a single flagellomere in the apomorphic condition of the antenna. While this process is denominated anarthrogenesis from a developmental point of view, from a phylogenetic perspective it is called symphysocery (Krell 1992). Indeed, symphysocery is widely present among beetles (Minelli 2004, 2017), and several groups of dung beetles show it. In the Neotropical fauna, two genera are defined, among other minor characters, based on the presence of 8-articulate antennae rather than the ancestral 9-articulate antennae of dung beetles, both in Dichotomiini: Chalcocopris Burmeister, 1846 and Isocopris Pereira \& Martínez, 1960 (Rossini \& Vaz-de-Mello 2015, 2017). Nevertheless, as detailed by Krell (1992), since anarthrogenesis in the antennal funicle seems to have little effect on the overall fitness of the individual bearing the mutation(s) responsible for it (contrary to anarthrogenesis in the apical lamellae, scape and pedicel, which interferes more directly with the functional roles of the antennae and, therefore, affects fitness), the number of articles in the antennal funicle seems to be fairly plastic among beetles, and convergences and parallelisms (due to either developmental constraints or selection of genes with pleiotropic effects on anarthrogenesis, or even genetic drift) are not expected to occur so rarely.

In Dichotomiini, in particular, it seems that there are some strong developmental constraints acting on the anarthrogenesis, since this group is particularly prone among dung beetles to show parallel cases of symphysocery. Consequently, Chalcocopris and perhaps Isocopris are most probably polyphyletic genera consisting of independent lineages nested within a paraphylum composed of a paraphyletic Dichotomius Hope, 1838 (that Chalcocopris is polyphyletic can also be inferred from the fact that both its species have little in common apart from the reduced number of antennomeres). Another problem related to the use of simple antennomere counting to trace the phylogenetic history of any beetle group is inherent with any meristic trait (meristic in the simple operational sense, not in Bateson's original ontological meaning; Bateson 1894): the reduction of the number of antennal articles can be the result of anarthrogeneses affecting different antennomeres. For instance, although the suppression of arthrogenesis between both articles IV and V+VI and articles V and VI will equally produce an 8-articulated antenna, the causal 
CUPELLO M. et al., Systematics of Streblopus and dung beetle biogeography

agent producing this particular antennomere count is completely distinct (in other words, not only the ultimate cause can be distinct, i.e., an 8-articulated antennae may evolve more than once independently, but also the proximate cause - the very developmental path through which an 8-articulated antenna is formed - may not be the same). Therefore, it is also pivotal to investigate the nature of the reduced condition in the number of antennomeres; that is, whether the reduction is a result of anarthrogeneses affecting the same antennomeres or different antennomere pairs. Instead of simply stating the number of antennomeres, perhaps it would be wiser to investigate which antennomeres are fused to produce such a number, as was done, for instance, by Tarasov \& Solodovnikov (2011) (in other words, which particular arthrogenesis has been suppressed).

Concerning particularly the case of S. punctatus (i.e., the supposed sub-Andean species), Halffter \& Martínez (1966) argued that the reduction in the number of antennomeres was a consequence of a mutation that fused articles III and IV (i.e., the first two basal articles of the funicle). While it is not possible to assert for sure whether the reduction was the result of a single mutation, Halffter \& Martínez (1966) seem to be correct in stating that the third visible antennomere of $S$. punctatus corresponds to the area covered by antennomeres III + IV in the antennae of $S$. opatroides and most of the other dung beetles. As can be seen in Fig. 7A-B, the third visible antennomere of $S$. punctatus is somewhat longer than the third antennomere of S. opatroides; the remaining articles, however, have all more or less the same length in both species. This shows that the third visible article of $S$. punctatus is indeed probably homologous to the area of articles III + IV of S. opatroides as argued by Halffter \& Martínez (1966). In summary, the reduction in the number of antennomeres in $S$. opatroides is most probably a consequence of the suppression of the arthrogenesis between the ancestor's first and second articles of the funicle. It is worth noting, though, that the shape of the two most apical articles of the funicle (i.e., articles V and VI of the ancestral form) is not the same in both species: in S. opatroides, these two articles - particularly antennomere VI - are broader than their homologues in the antennae of S. punctatus, having a more dish-like appearance in the first species.

\section{Labrum}

Few groups of New World Scarabaeinae have had their labra studied and illustrated in modern papers. Halffter (1961) showed that some remarkable intraspecific variation can be present in this structure, particularly concerning the chaetotaxy of the epipharynx (i.e., of the oral, or ventral (Edmonds 1972), surface of the labrum). Canthon (C.) vigilans LeConte, 1858, for instance, which is one of the most monomorphic North American species of Canthon in terms of its external morphology, was nevertheless shown to present an interesting case of clinal variation related to the number of setae on the lateral files of the epipharynx: in a northwest-southeast axis starting in states such as Michigan, Missouri and Kansas and ending in Florida, the average number of setae gradually increases from 12 up to about 15.5 (Halffter 1961). The number of setae in the lateral areas of the labrum was also shown to vary interpopulationally, although with no clear clinal pattern. As Halffter (1961) himself recognized, although those results were based on a limited number of specimens and, therefore, should not be taken as conclusive, they show that a painstaking study of the chaetotaxy of the epipharynx can reveal some interesting patterns of intraspecific variation that would be otherwise hidden from the entomologist. Unfortunately, however, except for a few other studies (co)authored by Gonzalo Halffter himself (e.g., Halffter 1952, 1955; Howden et al. 1956), we are unaware of any other papers that have used this character complex to investigate the alpha taxonomy of New World groups of Scarabaeinae. Studies on the high-level phylogeny of dung beetles, on the other hand, have dedicated themselves with more care to the morphology of the labrum, and have found that it can hold relevant phylogenetic information (e.g., Edmonds 1972; Philips et al. 2002, 2004a, 2004b; Forgie et al. 2005; Medina-Uribe 2015; Tarasov \& Génier 2015; Philips 2016; Tarasov \& Dimitrov 2016). Studies of Aphodiinae have also shown on a much broader scale that characters retrieved from the labrum can be useful for supraspecific classification (see Dellacasa et al. 2010 for more details). 
Motivated by these observations, we decided to study the labrum of Streblopus to investigate whether this structure varies between the sub-Andean and the Atlantic Forest metapopulations. To our surprise, we found that they are greatly divergent in these metapopulations: comparatively, the median area of the epipharynx of the sub-Andean specimens (Fig. 8D) is much more densely covered by short and thick, socketed setae than the homologous area in the epipharynx of the Atlantic Forest individuals (Fig. $8 \mathrm{~B}$ ); in the latter, the socketed setae are fewer in number, leaving a wide glabrous space on the central region of the median area, but those setae are longer and more curved than their counterparts in the subAndean specimens. The median brush of the labrum is also longer (and seems to be more projected) in the Atlantic Forest individuals than in the sub-Andean ones. The anterolateral regions of the labrum (possibly homologous to the pariae of the labrum in Aphodiinae; Dellacasa et al. 2010) are clearly projecting in Streblopus, making the anterior labral margin more or less 'U-shaped'. In the sub-Andean populations, however, this ' $U$ ' is much shallower than that seen in the Atlantic Forest populations; in other words, the space between the anterolateral regions in the latter seems to be much broader than in the former. Lastly, even the very shape of the anterolateral projections seems to vary between the two metapopulations: in the Atlantic Forest individuals, the external margin of the projections are more softly rounded, while it is more straight in the sub-Andean populations. Indeed, these are some of the most remarkable differences we observed between the metapopulations.

\section{Tegument punctation and microsculpture}

It is rather ironic that Balthasar (1938) named his new species S. punctatus (i.e., the sub-Andean metapopulation) based on a character that is much more pronounced in the Atlantic Forest $S$. opatroides, namely the presence of umbilicate punctation over the entire tegument. In the first metapopulation, the pronotal area between the eyes shows a very sparse umbilicate punctation, which nevertheless becomes increasingly denser towards the sides and the posterior region (Fig. 12B). In the Atlantic Forest, in turn, the entire pronotal surface is covered by dense umbilicate punctation, which also becomes denser towards the anterolateral angles and the posterior region (Fig. 12A). In both metapopulations, however, the punctures never become confluent, while the tegument between the umbilicate punctures always has diffuse microsculpture. Other areas of the tegument also show this clear tendency to have umbilicate punctation much denser in the Atlantic Forest individuals than in sub-Andean ones: the prosternum, mesoventrite, mesanepisterna, metanepisterna, metaventrite, mesocoxae, and meso- and metafemora of Atlantic Forest specimens show very dense umbilicate punctation, while those structures in sub-Andean individuals are all comparatively sparsely punctate. An exception is the ventral surface of the metatibiae, which are always devoid of punctation at its centre in the Atlantic Forest populations, while the subAndean populations in Ecuador have clear umbilicate punctation covering its entire length (however, individuals from southern Peru are similar to the Atlantic Forest ones). The tegument between the umbilicate punctures in all these structures have a clear, diffuse microsculpture in the Atlantic Forests specimens, while the microsculpture is extremely diffuse in all the sub-Andean ones. Finally, the striae on the elytra, although fine, are always complete in the Atlantic Forest populations (i.e., they are never interrupted before the apex of the elytra) and the interstriae are usually covered by umbilicate punctation (including the pseudepipleural carina, see Fig. 21B), showing a well-delimited alveolar microsculpture between the umbilicate punctures. In the sub-Andean individuals, in contrast, the striae are narrower and sometimes discontinuous, especially those on the pseudepipleura and the seventh stria on the disc, and the interstriae are covered by small umbilicate punctures, each puncture glabrous or with a short central seta, and these punctures are surrounded by diffuse microsculpture; the pseudepipleural carina, in particular, is almost entirely smooth and is not interrupted by a row of umbilicate punctures as in the Atlantic Forest metapopulation (Fig. 21C).

\section{Distal calluses of elytra}

Both metapopulations can easily be differentiated by how much the distal calluses of their elytra are developed. Sub-Andean populations have well-developed calluses, which are strongly projecting at the 
CUPELLO M. et al., Systematics of Streblopus and dung beetle biogeography

apical declivity of the elytra (Fig. 21E), while Atlantic Forest individuals have highly reduced calluses, which are much less evidently projected (Fig. 21D). The difference is so great that it is possible to note it even in a dorsal view, as can be seen by comparing Fig. 3A, C-D, depicting sub-Andean specimens, with Fig. 1A-C, showing Atlantic Forest ones. The reason for this variation, however, is unknown, especially taking into account that no differences in the overall configuration and venation of the hind wings were found between the two metapopulations (Fig. 21F).

\section{Secondary sexual characteristics}

A very peculiar characteristic of Streblopus, especially if we accept the idea that its species are rollers as discussed above, is its high level of sexual dimorphism. Although neither cephalic nor pronotal horns are present (features that are usually associated with paracoprid behaviour; Emlen \& Philips 2006), several other structures - particularly the legs - show sexual differences that are probably related in some way to the sexual behaviour of the group, possibly having some role in courtship, copulation or during agonistic encounters between males. In both species, the metaventrite is more strongly excavated posteriorly in males than in females (Fig. 13C-F; this excavation is much more pronounced in Atlantic Forest males than in sub-Andean ones, and the former also have a strong spur on the anterior edge of the excavation that is lacking in the latter) and the abdomen, in lateral view, is highly contracted in males (Fig. 22A) and flat in females (Fig. 22B). As for the legs, universal sexual dimorphism in the genus concerns the shape of the profemora, which are robust, strongly enlarged at the centre and have the anterior margin raised into one (sub-Andean populations) or two (Atlantic Forest ones) spurs in large males (Fig. 14A, C), while they are more linear and the anterior margin is simple in females; the shape of the protibiae, which are robust, curved both in- and downwards, have their apical region truncate and expanded inwards into a long spur with two transverse rows of setae (one covering the anterior edge of the apical lateral teeth, the other covering the long spur; Fig. 15A, C) and have the ventral carina interrupted by a longitudinal row of strong teeth in males (Figs 15E, G, 16A-B), but are more gracile in females, being only slightly bent inward and not bent downwards, having the internal angle of the apex projected into a short spur (Fig. $15 \mathrm{~B}, \mathrm{D}$ ), and the ventral carina simple, not interrupted by a row of teeth (Fig. 15F, H); the mesotibiae, whose apical expansion is a result of the internal edge being strongly projecting in males (Fig. 18A, C), whereas in females it is a result of a slight expansion of both the internal and external edges (Fig. 18B, D); metatrochanters, whose posterior edge is almost completely covered by a wide brush of long setae in males (Fig. 19B, D) and have only a thin brush of long setae in females (Fig. 19C, E); metatibiae, whose apical edges are strongly projecting inwards in males (Fig. 20A, C, E) and, while not expanded inwards, has a sharp spine at the internal angle in females (Fig. 20B, D, F); and the metatibial spur, which is only rudimentary in males, being much shorter than the basal metatarsomere in this sex (Fig. 20E), while it is well developed and much longer than the basal metatarsomere in females (Fig. 20F).

While the sexual differences discussed above concern all the populations studied for this paper, others are specific to either the sub-Andean metapopulation or the Atlantic Forest one. Atlantic Forest males have a clypeus evidently emarginate at the apex, with two tiny, but evident teeth flanking the emargination (Fig. 5C), whereas sub-Andean males have a clypeus that is only slightly emarginated at the apex and has very tiny teeth (Fig. 5E); females, on the other hand, have a clypeus similar to sub-Andean males in the Atlantic Forest (Fig. 5D), while its apical emargination is absent or only very slightly marked in the Amazonian sub-Andes (Fig. 5F). Therefore, there is a clear tendency towards a reduction in the degree to which the apical emargination is marked from the form seen in Atlantic Forest males towards the sub-Andean females.

Concerning the legs once again, the protibial spur is absent in Atlantic Forest males (Fig. 15A, E), while although very short, it is still present in sub-Andean males (Fig. $15 \mathrm{C}, \mathrm{G}$ ); in females, the protibial spur is always present, but in the Atlantic Forest it is bifurcated at the apex (Fig. 15B, F), whereas it is bent inwards apically and never bifurcated in the Amazonian sub-Andes (Fig. 15D, H). Females also 
diverge in the shape of the protibial teeth: in Atlantic Forest females the teeth decrease in size from the apical to the basal tooth and they are all apart from one another and always clearly directed laterally (Fig. 15B, F); in sub-Andean females the two most apical teeth are subequal in length, contiguous at the base and positioned far apart from the basal tooth, and all three teeth (especially the two most apical ones) are more or less directly forwards, not laterally (Fig. 15D, H).

Other differences in sexual dimorphism in the legs of the two metapopulations can be found on the mesofemora, the posterior edge of which has its basal half covered by a brush of long setae in Atlantic Forest males, while Atlantic Forest females and both sexes in the Amazonian sub-Andes lack this brush of setae (some few sparse setae may be seen in Amazonian males); on the mesotibiae there are two long rows of long setae on their internal edges in Atlantic Forest males (Fig. 18A), while Atlantic Forest females (Fig. 18B) and both sexes in the Amazonian sub-Andes (Fig. 18C-D) have only some sparse setae in that region; the male apical expansion of the mesotibiae is much broader in sub-Andean males (Fig. 18C) than in Atlantic Forest ones (Fig. 18A); the base of the metatibiae has a row of sharp teeth on its internal edge in Atlantic Forest males (Fig. 20A), while it lacks any sharp teeth in females of that region (Fig. 20B) or in both sexes of the sub-Andean populations (Fig. 20C-D); the apical edge of female metatibiae is laterally emarginated in Atlantic Forest individuals (Fig. 18B) and is entirely rounded in sub-Andean specimens (Fig. 18D); and the metafemora in Atlantic Forest males have a long, wavy spur on the posterior edge covered by a long brush of setae (Fig. 19B), while in sub-Andean males they have a brush of long setae covering the basal two-thirds of their non-crenulate posterior edge and have a small spur bent inwards rising just after the trochanter (Fig. 19D); in females, the metafemora lack any kind of spurs and are either devoid of brushes of setae (Atlantic Forest populations; Fig. 19C) or have the basal two-thirds of their crenulate posterior edge covered by a brush of sparse long setae (sub-Andean populations; Fig. 19E).

A final form of sexual dimorphism that has not yet been mentioned and that merits separate discussion concerns the tegument of the mesofemora. In males of both metapopulations, the posterior edge of those structures is densely covered by alveolar microsculpture and umbilicate punctation (Fig. 17E). In females, on the other hand, the microsculpture is always diffuse (as diffuse as on the rest of the mesofemoral surface), and the concentration of umbilicate punctures is very high (Fig. 17F; since the entire surface of the mesofemora of Atlantic Forest females is covered by dense umbilicate punctation, it is more difficult to note that the concentration of umbilicate punctures is higher on the posterior edge than in sub-Andean females). The reason for these differences is yet not clear, but we suppose it has something to do with chemical communication during reproduction (see Cupello \& Vaz-de-Mello 2018 for a brief discussion on the putative functional role of some analogous sexual differences in the tegument of another dung beetle genus, Sylvicanthon Halffter \& Martínez, 1977).

\section{Terminalia}

The terminalia of both sexes show differences between the metapopulations. Concerning the male genitalia, in both metapopulations the parameres are asymmetrical, with the right paramere showing an apical expansion (Fig. 23A-H). They are distinct, however, in that the sub-Andean males have a much more pronounced apical projection, which is broadly rounded and has an external spine (Fig. 23E-H), while in the Atlantic Forest males the apical projection is more discreet, although still clearly discernible (Fig. 23A-D). Other differences in the parameres is that Atlantic Forest males have their external edges more curved, whereas they are more or less straight in sub-Andean males and, in lateral view, the ventral side of the parameres of sub-Andean males is straight (Fig. 23G, red arrow), while in Atlantic Forest ones it has a straight base and a strong inclination towards the apex (Fig. 23C, red arrow); that inclination is a result of the presence of a pair of strong ventral keels (Fig. 23B, red arrow), while these structures are absent in sub-Andean individuals. 
CUPELLO M. et al., Systematics of Streblopus and dung beetle biogeography

The axial+subaxial pair of internal sac sclerites is also extremely divergent between the two metapopulations. Atlantic Forest males have both sclerites very similar to one another in being simply curved, the axial sclerite a little shorter than the subaxial one (Fig. 24E-F), while in sub-Andean males both are fairly distinct in shape, with the subaxial sclerite having a curved apex enclosing the apex of the axial sclerite, which is simply curved and shorter than the subaxial sclerite (Fig. 25D). The superior right peripheral sclerite (SRP), on the other hand, is very similar in both metapopulations (Figs 24D, $25 \mathrm{E}$ ), whereas the raspule, although similar in shape in both metapopulations, differs between them in its exact location in the internal sac (Figs $24 \mathrm{~A}-\mathrm{C}, 25 \mathrm{~A}-\mathrm{C}$ ).

The medial sclerotized plate (MSP) of the genital segment is more sclerotized in sub-Andean males than in the Atlantic Forest ones. Furthermore, its shape also differs between the two metapopulations: their lateral arches are straight in sub-Andean specimens (Fig. 26B, blue arrow), whereas they are concave in Atlantic Forest ones (Fig. 26A, blue arrow), and the posterior arms of the MSP are well developed and separated from one another by a deep 'U-shaped' emargination in sub-Andean males (Fig. 26B, red arrow), while they are only slightly indicated and have no clear emargination between them in Atlantic Forest individuals (Fig. 26A, red arrow).

In relation to females, the only papers we are aware of that studied the morphology of their genitalia in an alpha taxonomic context among New World taxa are the publications by Rossini et al. (2018) on Onthophagus Latreille, 1802, Cupello \& Vaz-de-Mello (2013b) on Gromphas Brullé, 1838 and Kohlmann $(1981,1984)$ on North American Ateuchus Weber, 1801. Unlike Rossini et al. (2018) and Cupello \& Vaz-de-Mello (2013b), who did not find any differences in the spermatheca among the species they studied, but in agreement with Kohlmann $(1981,1984)$, we observed some remarkable distinctions between the two metapopulations of Streblopus. The spermatheca of Atlantic Forest females (Fig. 27A) is, as a whole, broader than that of sub-Andean females (Fig. 27B), in particular the basal branch, while the more slender spermatheca of the latter metapopulation has the apical branch proportionally much longer than the basal branch and, more importantly, has an apical pair of hooks that is not seen in the Atlantic Forest females nor, as far as we know, in any other Scarabaeinae. The other structures in the female genitalia are completely membranous in both metapopulations and no differences were observed (Fig. 27C).

\section{Distribution and evolution}

Putting together all the morphological differences discussed in the previous sections, we can see very vividly that we are dealing with two distinct species, each represented by one of the metapopulations. Halffter \& Martínez (1966) were right, after all, in regarding the differences noted between the Peruvian female of $S$. punctatus and the three male $S$. opatroides examined by them not as sexual dimorphism within the same species, but rather as species differences. The two species are completely allopatric: $S$. opatroides is endemic to a limited region of the Brazilian Atlantic Forest, inhabiting lowland patches of ombrophilous forests across the coast of Bahia and Espírito Santo, while S. punctatus lives much farther inland in South America, inhabiting Sub-Andean evergreen forests between 600 and $\sim 1500 \mathrm{~m}$ a.s.l. in the Peruvian and Ecuadorian Amazon forest (Fig. 4). Such a widely disjunct distribution is quite remarkable and shows that Streblopus was once a much more widely distributed genus, and that its two living species are the sole remnants of a probably richer clade. The contrast between the habitats in which they live and the biological communities of which they are part, associated with the different evolutionary pressures they exert and sexual selection, are probably responsible for much of the interspecific variation listed above. However, since Streblopus is evidently a relict genus and both its species are so widely separated from one another in terms of distribution, it is possible that they have been evolving independently for a long period of time. Therefore, the above morphological differences are not simply the result of different pressures from natural and sexual selection and from chance, but 
Table 1. Dung beetle lineages distributed across the Amazonia, the South American Dry Diagonal and the Atlantic Forest.

\begin{tabular}{|c|c|c|c|}
\hline Lineage & & $\begin{array}{l}\text { No. of } \\
\text { species }\end{array}$ & References \\
\hline Dichotomius Hope, 1838 & quadraticeps group & 21 & Nunes \& Vaz-de-Mello 2019 \\
\hline \multirow{3}{*}{ Coprophanaeus d'Olsoufieff, 1924} & $\begin{array}{l}\text { Megaphanaeus } \\
\text { d'Olsoufieff, } 1924\end{array}$ & 4 & $\begin{array}{l}\text { Edmonds \& Zídek 2010; } \\
\text { Maldaner et al. } 2018\end{array}$ \\
\hline & jasius group & 7 & Edmonds \& Zídek 2010 \\
\hline & dardanus group & 10 & $\begin{array}{c}\text { Edmonds \& Zídek 2010; } \\
\text { Cupello \& Vaz-de-Mello 2013b }\end{array}$ \\
\hline Gromphas Brullé, 1838 & & 6 & Cupello \& Vaz-de-Mello 2013a, 2016 \\
\hline \multirow{2}{*}{ Ontherus Erichson, 1847} & appendiculatus group & 9 & Génier 1996 \\
\hline & brevipennis group & 10 & Génier 1996 \\
\hline Genieridium Vaz-de-Mello, 2008 & & 7 & Vaz-de-Mello 2000 \\
\hline \multirow{3}{*}{ Eurysternus Dalman, 1824} & inflexus group & 3 & Génier 2009 \\
\hline & hirtellus group & 12 & Génier 2009 \\
\hline & caribaeus group & 5 & Génier 2009 \\
\hline Ateuchus Weber, 1801 & pygidialis group & 8 & MC, unpublished data \\
\hline
\end{tabular}

also from the accumulation of these three factors over a long period of time. But for how long have they been evolving separately? To answer this question, it is essential to know when their habitats were connected for the last time by bridges of suitable environments from the Streblopus perspective.

Between the distribution ranges of the sub-Andean (i.e., Western Amazonian) S. punctatus and the Atlantic Forest $S$. opatroides lies a vast area of more open and drier environments, mostly constituted by grasslands, thorn forests and xeric shrublands, known as the South American Dry Diagonal. Different groups of dung beetles respond in different ways to this large-scale mosaic of environments. For instance, some lineages of closely related species are able to occupy both the tropical forests in the Amazon Basin and in the Atlantic Forest as well as the drier habitats in between (Table 1). Other lineages are limited either to Amazonia (Table 2), the Dry Diagonal (Table 3) or the Atlantic Forest (Table 4). Finally, a third distributional pattern found among South American dung beetles is the one shown by Streblopus: lineages that are present in both Amazonia and the Atlantic Forest, but which are absent from the Dry Diagonal (Table 5).

Since the lineages showing the latter distribution pattern, including Streblopus, are present in the tropical rainforests on both sides of the Dry Diagonal, but do not occur in the latter region, we can assume that open and dry environments do not provide the minimal conditions for populations of those different groups of lineages to settle themselves and survive for a long period of time. Thus, we are left with two possibilities: either, in the past, the areas now part of the Dry Diagonal were once covered by humid forests that allowed biotic movement between the Atlantic Forest and Amazonia, and, eventually, those forests died out and the once-widespread lineages were confined to the remaining tropical forests on both sides of the Dry Diagonal, or the ancestors of each lineage were somehow able to cross thousands of kilometres of unsuitable conditions and establish a new population on the other side of the Dry Diagonal.

One living species of dung beetle, Coprophanaeus (C.) dardanus (MacLeay, 1819), is a peculiar example of a species that shows this 'cis-Dry Diagonal' distribution pattern by itself and that, consequently, can tell us how such a pattern can arise. Coprophanaeus dardanus is distributed across the Atlantic 
CUPELLO M. et al., Systematics of Streblopus and dung beetle biogeography

Table 2. Dung beetle lineages endemic in South America east of the Andes to the Amazonia.

\begin{tabular}{cccc}
\hline Lineage & & $\begin{array}{c}\text { No. of } \\
\text { species }\end{array}$ & References \\
\hline Hansreia Halffter \& Martínez, 1977 & 6 & Valois et al. 2015 \\
\hline Sylvicanthon Halffter \& Martínez, 1977 & bridarollii subgroup & 4 & Cupello \& Vaz-de-Mello 2018 \\
\hline Dichotomius Hope, 1837 & mamillatus group & 4 & Rossini \& Vaz-de-Mello (in press) \\
\hline Onthophagus Latreille, 1802 & osculatii complex & $4^{*}$ & Rossini et al. 2018 \\
\hline Phanaeus MacLeay, 1819 & chalcomelas group & 5 & $\begin{array}{c}\text { Edmonds 1994; } \\
\text { Edmonds \& Zídek 2012 } \\
\text { Edmonds 1994; }\end{array}$ \\
\hline Ontherus Erichson, 1847 & bispinus group & 2 & Edmonds \& Zídek 2012 \\
\hline
\end{tabular}

* 4 in the Amazonia (plus 1 in Chaco and 3 in areas west of the Andes)

Forest from the northern region of the Brazilian state of Paraná northwards to the last forest remnants in the states of Pernambuco and Alagoas; to the west, there are some scattered records from moistforest enclaves in mountain ranges in the middle of the xerophytic Caatinga vegetation in the state of Ceará (localities such as the Parque Nacional de Ubajara); and, then, farther east, the species is widely distributed in the eastern half of the Amazon forest, being replaced by the closely allied species C. (C.) telamon (Erichson, 1847) in the western half (Edmonds \& Zídek 2010; Cupello \& Vaz-deMello 2013a). The presence of $C$. dardanus in the Caatinga moist forest enclaves shows us that, during interglacial periods in which humidity and temperature were higher and, consequently, much of the region that is today covered by open environments were tropical evergreen forests, the species had a continuous distribution from the eastern half of the Amazon Basin to the northern part of the Atlantic Forest. With the end of those interglacial periods, most of the forest cover retreated, giving space to drier open vegetation, but some forest patches remained in areas of particularly higher humidity such as mountain ranges and river banks. Therefore, these isolated 'forest islands' (or 'oases') became refuges for forest species that once lived across the forest belt connecting Amazonia and the Atlantic Forest.

Based on bird evidence, Batalha-Filho et al. (2013) showed that such a forest belt indeed existed across the coast of the states of Maranhão, Piauí, Ceará and Rio Grande do Norte, during wetter periods of the Plio-Pleistocene. The Ceará populations of $C$. dardanus, therefore, are a relict of an once more widely distributed species and thus are a living example of the process that certainly occurred with the ancestors of at least most of the 'cis-Dry Diagonal' lineages mentioned above, including Streblopus. Other dung beetle species with relict populations in tropical forest refuges in the heart of the Caatinga are Coprophanaeus (Megaphanaeus) bellicosus (Olivier, 1789) (Silva 2011), which is also present in much of the Brazilian Atlantic Forest (Edmonds \& Zídek 2010), and Ateuchus simplex (Lepeletier de SaintFargeau \& Audinet-Serville, 1828), a species widely distributed in Amazonia and which has a single known relict population in a forest refuge in Carquêja, Ceará, Brazil (MC, unpubl. data). Dichotomius (Luederwaldtinia) machadoi Martínez \& Pereira, 1967 and Canthon (C.) machadoi (Martínez \& Pereira, 1967), in turn, are even more extreme examples of this relict condition, for they are both endemic to one such enclave in the state of Pernambuco (Martínez \& Pereira 1967; Cupello \& Vaz-de-Mello 2018).

Although we cannot rule out the hypothesis that Streblopus was once distributed over the northern part of the Atlantic Forest and in much of the Amazon forest and, therefore, could have crossed the Dry Diagonal through the same forest belt crossed by $C$. dardanus over the coast of northeastern Brazil, a vast body of studies have shown that several other, much older corridors existed during different times of the Neogene (last $\sim 23$ million years) connecting Amazonia and the Atlantic Forest through which southern 
Table 3. Dung beetle lineages endemic to the South American Dry Diagonal.

\begin{tabular}{cccc}
\hline Lineage & & $\begin{array}{c}\text { No. of } \\
\text { species }\end{array}$ & References \\
\hline Dichotomius Hope, 1838 & ingens group & 5 & Nunes \& Vaz-de-Mello 2019 \\
\hline Phanaeus MacLeay, 1819 & palaeno group & 3 & Edmonds 1994; Edmonds \& Zídek 2012 \\
\hline Zonocopris Arrow, 1932 & & 2 & Vaz-de-Mello 2007a \\
\hline Deltochilum Eschscholtz, 1822 & $\begin{array}{c}\text { cupreicolle complex } \\
\text { valgum complex }\end{array}$ & 4 & Silva et al. 2015 \\
Canthon Hoffmannsegg, 1817 & $\begin{array}{c}\text { Pseudepilissus } \\
\text { Martínez, 1954 }\end{array}$ & 2 & Silva et al. 2015 \\
\hline Holocanthon & & 2 & Vieria et al. 2019 \\
\hline Martínez \& Pereira, 1956 & & Sawaris et al. 2019 \\
\hline Ateuchus Weber, 1801 & puncticollis group & 5 & MC, unpublished data
\end{tabular}

populations in both biomes have crossed from one area to the other (e.g., Costa 2003; Batalha-Filho et al. 2013; Ledo \& Colli 2017; Trujillo-Arias et al. 2017, 2018; Cabanne et al. 2019; Melo et al. 2019; and papers cited therein). Cupello \& Vaz-de-Mello (2018), for instance, hypothesized that the ancestors of Sylvicanthon foveiventris (Schmidt, 1920) and S. obscurus, the only species of their respective species groups to be present in the Atlantic Forest, arrived in the latter biome from the southern part of the Amazon Forest through some of those corridors. It is probable, then, that the ancestral distribution of Streblopus covered at least one of those southern forest belts (Fig. 28; see Ledo \& Colli 2017 for more details on the main routes connecting the two biomes during the Neogene). Then, during the drier periods of the Neogene, the tropical forests retreated, the distribution area of Streblopus shrunk and, eventually, the two currently independent species became isolated from one another in the way we see today. When exactly that process occurred is still unknown, but Ledo \& Colli (2017) have shown that the greater part of disjunct distributions between southern Amazonian and central-southern Atlantic Forest taxa are much older than the ones between eastern Amazonia and northern Atlantic Forest groups. This pattern is observed among dung beetles as well: whereas population-level disjunctions are found in the latter regions, e.g., the examples of Coprophanaeus dardanus and Ateuchus simplex discussed above, species- or clade-level disjunctions are the rule for the former. What is certain is that the entire process occurred sometime over the last 23 million years, which indicates that both species have had a long time in isolation to develop and accumulate the morphological differences we discussed above. Whether these morphological differences evolved at a gradual pace over that period of time or there were one or more periods of rapid changes followed by morphological stasis is still unknown.

\section{Macroevolutionary history of Streblopus}

\section{Phylogenetic relationships with other dung beetle lineages}

As discussed in the Introduction, one of the most intriguing aspects about Streblopus is its phylogenetic relationships with other dung beetle lineages, since this genus has been considered an isolated element within the South American fauna. Harold (1868), who was the first to publish about Streblopus (albeit under the name Colonychus), argued that the genus represented a kind of link between what he called the African "Epirhinen" (i.e., Epilissus and allied forms) and the New World genus Canthon. Van Lansberge (1874a), in turn, deemed Streblopus a genus of unknown placement among the dung beetle groups, saying it shared some unique similarities with as diverse groups as Deltochilum, Onitis, Mentophilus and Byrrhidium. Later that year, however, Van Lansberge (1874b) classified the genus in his "Epirides" along with Mentophilus, Epirinus, Labroma and Coproecus; this group of genera was subordinated to the "Menthophilides", which, in turn, was part of the "Canthonides". During the $20^{\text {th }}$ century, all authors who have in some way dealt with Streblopus have accepted part of this classification and treated 
CUPELLO M. et al., Systematics of Streblopus and dung beetle biogeography

Table 4. Dung beetle lineages endemic to the Atlantic Forest.

\begin{tabular}{cccc}
\hline Lineage & & $\begin{array}{c}\text { No. of } \\
\text { species }\end{array}$ & References \\
\hline Dichotomius Hope, 1838 & ascanius group & 3 & Nunes \& Vaz-de-Mello 2019 \\
& sericeus group & 8 & Valois et al. 2017 \\
& spadiceus group & 3 & Nunes \& Vaz-de-Mello 2019 \\
& speciosus group & 4 & Maldaner et al. 2015 \\
\hline Aphengium Harold, 1868 & & 4 & Silva \& Vaz-de-Mello 2015 \\
\hline Paracanthon Balthasar, 1838+ & & 17 & Pacheco \& Vaz-de-Mello 2017, \\
Paracryptocanthon & & 2020 \\
\hline Howden \& Cook, 2002 & deplanatus group & Génier 2009 \\
\hline Canthon Hoffmannsegg, 1817 & Peltecanthon Pereira, 1953 & 4 & Nunes et al. 2020 \\
\hline Deltochilum Eschscholtz, 1822 & finestriatum complex & 3 & Silva et al. 2015 \\
\hline Ontherus Erichson, 1847 & erosus group & 3 & Génier 1996
\end{tabular}

the genus among the Canthonini/Deltochilini (e.g., Kolbe 1905, 1907; Gillet 1911; Paulian 1938, 1939; Balthasar 1941, 1951; Blackwelder 1944; Pereira \& Martínez 1956; Vulcano \& Pereira 1964, 1967; Halffter \& Martínez 1966, 1968, 1977; Halffter \& Matthews 1966; Halffter \& Edmonds 1982; Halffter 2003), although at least two of those papers have explicitly recognized that this was anything but conclusive (Paulian 1939; Halffter \& Martínez 1966). More recently, however, three works have challenged this long-standing classification.

Medina-Uribe (2015), in a morphological phylogenetic analysis of the Deltochilini, found that Streblopus opatroides was the first species to branch out in her cladogram, which indicated to her that the genus was not closely related to the Deltochilini/Canthonini (which she considered to be two independent tribes). She then argued that the asymmetrical parameres of the genus were similar to the condition seen in the Australian Canthonosoma MacLeay, 1871, and for that reason Streblopus could be related to the Mentophilini. Vaz-de-Mello (2007b) made a similar case and stated that Streblopus "much probably" belongs to a Menthophilini consisting of the Australasian genera Menthophilus, Labroma, Coproecus, Canthonosoma, Cephalodesmius Westwood, 1841 and Aulacopris White, 1859. They resurrected, therefore, a classification that Van Lansberge (1874a, 1874b) himself had already put forward more than a century earlier when he placed Streblopus in his "Menthophilides" (although the generic constitution of Van Lansberge's scheme did not completely match the less-inclusive classification of Vaz-de-Mello 2007).

Were Medina's (2015) and Vaz-de-Mello's (2007) hypotheses correct, a logical explanation for the current disjunct distribution of Streblopus in South America and the other "Menthophilini" in Australasia would be a classic Gondwanan distribution for the ancestor of the group followed by the fragmentation of the old supercontinent and the isolation of Streblopus and the other "Menthophilini" on their respective continents. Nevertheless, we are now of the opinion that, in fact, very little evidence exists supporting this view of a close relationship between Streblopus and those Australasian taxa. The only point raised by Medina-Uribe (2015) to support her hypothesis - an alleged similarity between the parameres of Streblopus and Canthonosoma - is highly questionable: not only are asymmetrical parameres not exclusive to those two genera (in fact, she herself showed in Medina et al. (2013) that many other dung beetles have highly asymmetrical parameres, and we have personally observed this condition in several South American species of Canthon s. str., Glaphyrocanthon Martínez, 1948 and 
Table 5. Dung beetle lineages occurring in both the Amazonia and the Atlantic Forest, but absent from the South American Dry Diagonal. As discussed in the text, such a disjunct distribution was caused by the past existence of forest corridors connecting both forest biomes over several different periods of the Neogene.

\begin{tabular}{cccc}
\hline Lineage & & $\begin{array}{c}\text { No. of } \\
\text { species }\end{array}$ & References \\
\hline Sylvicanthon Halffter \& Martínez, 1977 & $\begin{array}{c}\text { candezei subgroup } \\
\text { furvus subgroup }\end{array}$ & 3 & $\begin{array}{c}\text { Cupello \& Vaz-de-Mello 2018 } \\
\text { Cupello \& Vaz-de-Mello 2018 }\end{array}$ \\
\hline Scybalocanthon Martínez, 1948 & 24 & $\begin{array}{c}\text { Silva \& Valois 2019; } \\
\text { Silva \& Génier 2019 }\end{array}$ \\
\hline Canthon Hoffmannsegg, 1817 & $\begin{array}{c}\text { Goniocanthon } \\
\text { Pereira \& Martínez, 1956 }\end{array}$ & 3 & Nunes et al. 2018 \\
\hline Eurysternus Dalman, 1824 & calligrammus group & 4 & Génier 2009 \\
\hline Dichotomius Hope, 1838 & fissus group & 6 & Nunes \& Vaz-de-Mello 2019 \\
\hline Phanaeus MacLeay, 1819 & splendidulus group & 5 & $\begin{array}{c}\text { Edmonds 1994; } \\
\text { Edmonds \& Zídek 2012 }\end{array}$ \\
\hline Oxysternon Castelnau, 1840 & Mioxysternon & 3 & $\begin{array}{c}\text { Edmonds \& Zídek 2010; } \\
\text { França } \text { et al. 2012 }\end{array}$ \\
\hline Streblopus Van Lansberge, 1874 & Edmonds, 1972 & 2 & present paper \\
\hline
\end{tabular}

in the peculiar vigilans group of Ateuchus, to mention just a few cases), but even the way in which the parameres are asymmetrical is extremely distinct between Streblopus and Canthonosoma, as Medina et al. (2013: figs 64-65) clearly showed. Indeed, it is quite difficult to say what the parameres of these two genera have in common besides the fairly general statement that they are asymmetrical. Therefore, we will not follow the hypotheses of Medina-Uribe (2015) and Vaz-de-Mello (2007) herein.

It is worth mentioning, though, that in a previous work, Medina \& Scholtz (2005) had noted that the African genus Epirinus shared some similarities (without listing which) with Streblopus, Eudinopus and three other African genera, namely Circellium Latreille, 1825, Chalconotus (as Anachalcos; see Branco 2011 for the validity of these names) and Gyronotus Van Lansberge, 1874. Curiously enough, four of those six genera, viz., Streblopus, Circellium, Chalconotus and Gyronotus, were hypothesized to form a clade with the Scarabaeini supported by two synapomorphies in Tarasov \& Génier (2015), the most comprehensive dung beetle phylogenetic analysis based on morphological data so far published; as for the other two genera, Epirinus appeared very distantly related to the aforementioned clade, as the sister group to the Sisyphini (to which it was finally transferred in Tarasov \& Dimitrov 2016, with subsequent criticism by Daniel et al. 2018), whereas Eudinopus was not included in the analysis. The two synapomorphies hypothesized by Tarasov \& Génier (2015) to support that clade were the independent losses of male and female protarsi, conditions that evolved in parallel in other lineages of dung beetles. Within the clade, the first split was between Gyronotus + Chalconotus (a clade supported by one synapomorphy, namely a peculiar shape of the subaxial sclerite) and the other three genera, which are united by two synapomorphies (the losses of the fronto-lateral peripheral sclerite (FLP) and that of the basisternal furca of the prothorax); the latter lineage, in turn, is divided between Streblopus and Circellium +Scarabaeini, the latter clade supported by one synapomorphy related to the axial and subaxial sclerites of the internal sac. In the context of Tarasov \& Génier (2015), Streblopus opatroides, the only species of the genus included in the analysis, appeared with two controversial autapomorphies: the gain of the lateral labial sclerite of the hypopharyngeal suspensorium and a putative loss of the protibial spur. 


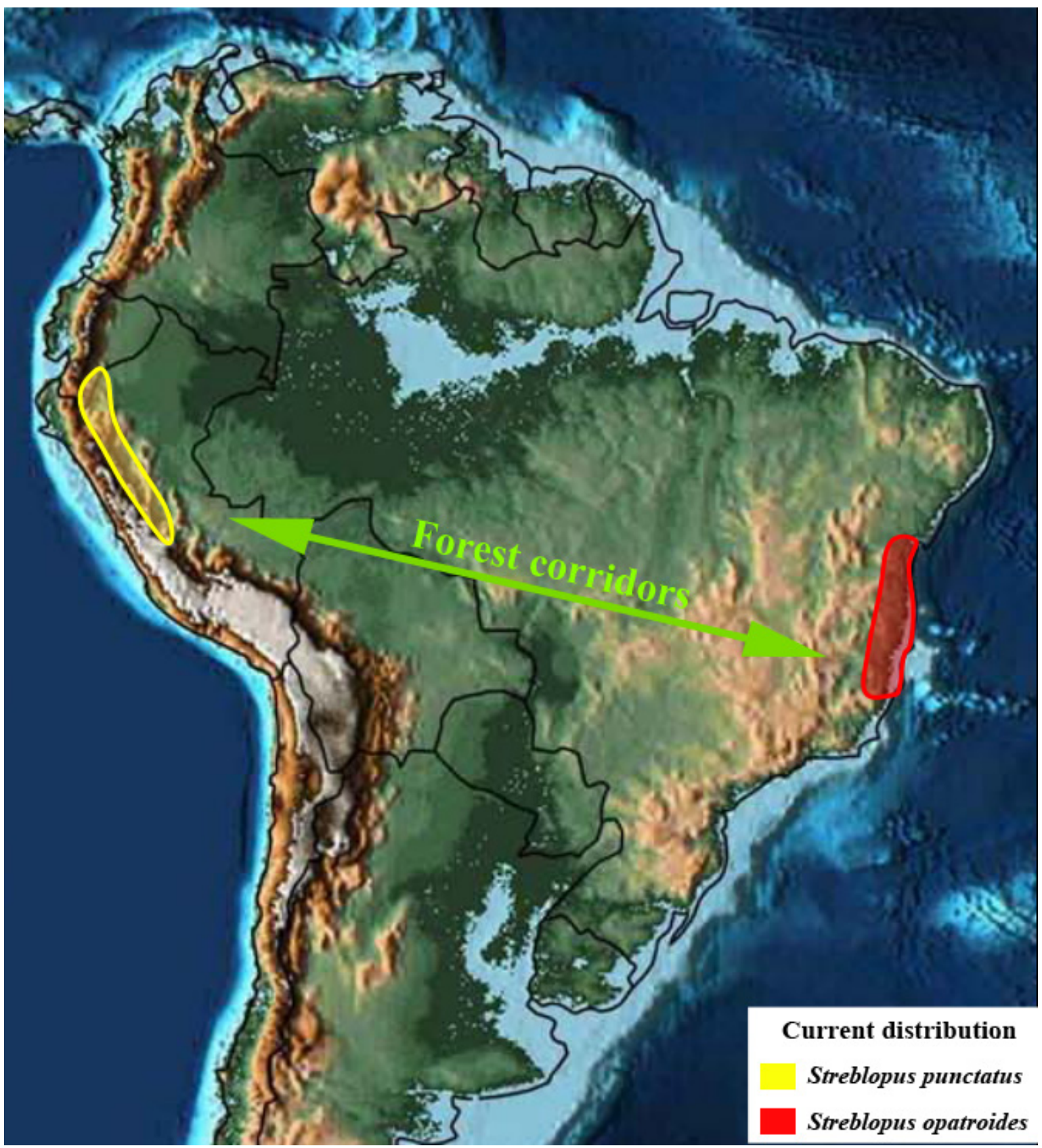

Fig. 28. Current distribution of Streblopus van Lansberge, 1874 plotted on a Middle Miocene palaeomap ( $\sim 15$ million years ago). Presently, both species of Streblopus are largely isolated from one another by means of the South America Dry Diagonal that separates the humid forests of the Amazon Basin from the Atlantic Forest on the South American eastern coast. This disjunct distribution is probably a result of the fragmentation of an once much more widely-distributed genus, which crossed the Dry Diagonal from the Atlantic Forest to southwestern Amazonia through forest corridors connecting those two biomes during periods of warmer climate over the past 25 million years. When the climate cooled and the tropical forests retreated, the open and drier environments of the Dry Diagonal advanced, and the populations of Streblopus in the Atlantic Forest and in the Amazon became isolated. It is known that the Middle Miocene experienced the highest temperatures of the last 20 million years (Zachos et al. 2001), and perhaps it was during its 'climate optimum' about 15 million years ago that the Amazonian and the Atlantic Forest populations of Streblopus were connected for the last time. Palaeomap modified from Scotese (2016). 
Despite some minor inconsistencies (for instance, only males of $S$. opatroides lack a protibial spur, while females have it completely developed), Tarasov \& Génier's findings are persuasive and seem to finally propose a convincing position for Streblopus among the dung beetle lineages. Furthermore, part of that topology had already been proposed in previous phylogenetic analyses: a sister-group relationship between Circellium and Scarabaeini has been repeatedly hypothesized in other morphological papers such as Philips et al. (2004a) and Vaz-de-Mello (2007b) and, more recently, in the maximum likelihood analyses of the molecular phylogenetic study of Tarasov \& Dimitrov (2016). Indeed, Circellium had been considered a member of Scarabaeini by most authors until the last third of the $20^{\text {th }}$ century (e.g., Péringuey 1901; Ferreira 1972). Unfortunately, however, none of those papers or any other broadscale publications on the phylogeny of dung beetles have so far included Streblopus in their analyses, hampering a direct comparison with the results in Tarasov \& Génier (2015). A close inspection of the evidence put forward by the latter authors to support their hypothesis of a close relationship between Streblopus and Circellium + Scarabaeini will show, however, why we support their proposal.

As discussed above, the synapomorphies hypothesized by Tarasov \& Génier (2015) to support the Streblopus (Circellium + Scarabaeini) clade were two losses. The FLP sclerite evolved independently in a very distant ancestor of that lineage (i.e., the common ancestor of the clade denominated " $G$ " by the authors less Bohepilissus sp.) and in the ancestor of clade $\mathrm{F}_{1}$ less $\mathrm{F}_{2}$, an assemblage comprising Ateuchina and some genera that Vaz-de-Mello (2008) had put in incertae sedis in Ateuchini. The absence of this sclerite in Streblopus, Circellium and Scarabaeini indeed seems to be secondary (i.e., apomorphic), since not only are these groups deeply nested within a clade where the other species have the FLP sclerite, but also because there is a clear tendency among them towards a simplification (i.e., a loss of sclerotization) in the internal sac sclerites. Both species of Streblopus have only three sclerites (the axial (A), subaxial (SA) and superior right peripheral (SRP) sclerites). These are also the only sclerites present in the internal sac of Circellium bacchus (Fabricius, 1781) (Medina et al. 2013; Tarasov \& Génier 2015), the only species of its genus (Scholtz \& Howden 1987; Davis et al. 2008), as well as in all the species of Scarabaeini for which the internal sac has been illustrated in the literature (Barbero et al. 1998; Medina et al. 2013; Tarasov \& Génier 2015).

Another similarity between these groups is the very shape of the sclerites: in all of them, the apical and subapical sclerites are falciform (i.e., long and broadly curved) and, although superimposed in resting position, they are only loosely connected to one another and easily separable. As discussed by Medina et al. (2013) (under the name "elongate sclerite") and richly illustrated by them and by Tarasov \& Génier (2015), the shape of these paired sclerites is extremely plastic among the Scarabaeinae, and therefore the profound similarity found in the forms seen in Streblopus, Circellium and Scarabaeini should be homologous. Indeed, it seems that the synapomorphy pointed out by Tarasov \& Génier (2015) to support the clade Circellium + Scarabaeini (namely, SA and A sclerites long and occupying at least the entire inferior half of the internal sac) is, in fact, a synapomorphy of Streblopus + Circellium + Scarabaeini, for that is exactly the condition seen in Streblopus. If this observation is correct, then it is possible that Streblopus is more closely related to either Scarabaeini or Circellium than these two taxa are to one another. Finally, the shape of the superior right peripheral sclerite is also indicative of a close relationship between Streblopus, Circellium and Scarabaeini, since little difference exists between them in that regard. In summary, therefore, the whole conjunct of the internal sac, with its reduction in sclerotization (in other words, its simplification) and presence of only three sclerites of a fairly conserved general shape across different lineages (i.e., the SA, A and FLP), is here interpreted as a complex of homologies shared by Streblopus, Circellium and Scarabaeini.

As for the second synapomorphy pointed out by Tarasov \& Génier (2015) to support the clade Streblopus (Circellium +Scarabaeini), the loss of the basisternal furca of the prothorax, very little is known about this structure. Located on the interior of the anterolateral angle of the prothorax, this structure was 
CUPELLO M. et al., Systematics of Streblopus and dung beetle biogeography

first observed by Tarasov \& Génier (2015) and its presence was hypothesized by them to be one of the synapomorphies of Scarabaeinae. According to the authors, the shape and degree of sclerotization of the basisternal furca vary across the dung beetles, and their phylogenetic hypothesis accounts for at least five other losses besides that of Streblopus (Circellium + Scarabaeini): one by the ancestor of Coptorhina Hope, $1830+$ Delopleurus Erichson, 1847, three other independent losses by the ancestors of the genera Coptodactyla Burmeister, 1846, Sinapisoma Boucomont, 1828 and Boletoscapter Matthews, 1874 and, finally, by the ancestor of a wide clade composed of the Dichotomiini, Eucraniini, Phanaeini, Coprini, Onitini and several incertae sedis paracoprid genera. It is worth noting that, although Tarasov \& Génier's character matrix also codes the basisternal furca as absent in the clade Onthophagini+Oniticellini, a possible loss of this structure is not plotted as being a synapomorphy of that clade in their cladogram. So, despite being such a plastic character in the evolutionary history of dung beetles, so liable to reductions and even complete suppressions, the loss of the basisternal furca seems to be compelling evidence for the monophyly of Streblopus + Circellium + Scarabaeini, since many of the lineages positioned close to this group in their phylogeny (e.g., Gymnopleurini, Eurysternini, Deltochilini and Sisyphini; but not Onthophagini + Oniticellini) do posses that structure (Tarasov \& Génier 2015). Therefore, the absence of the basisternal furca is a peculiar derived character state of the clade Streblopus + Circellium + Scarabaeini in the immediate phylogenetic context in which it is inserted.

Those two complexes of synapomorphies, therefore, strongly support the view that Streblopus is closely related to a clade with an exclusive Old World distribution, perhaps even nested within such a clade, should Gyronotus + Chalconotus indeed be the sister group to Streblopus + Circellium + Scarabaeini, as hypothesized by Tarasov \& Génier (2015), or should Streblopus be more closely related to either Circellium or Scarabaeini than they are to one another. Moreover, Tarasov \& Génier's phylogenetic study clearly shows that Streblopus has no direct relationship with the Deltochilini or any other New World groups. The two synapomorphies pointed out by Tarasov \& Dimitrov (2016) to support their new definition of Deltochilini are indeed absent in Streblopus: the $\mathrm{RA}_{4}$ hind wing vein runs parallel to the $\mathrm{RP}_{1}$ vein and is not fused to it basally in Streblopus (Fig. 21F), while those veins are divergent and fused basally in Deltochilini, and the so-called 'basal sclerite' of the $\mathrm{RP}_{1}$ vein (see Tarasov \& Génier 2015 and Tarasov \& Dimitrov 2016 for more details) is apomorphically present in Deltochilini and plesiomorphically absent in Streblopus. Therefore, if all this phylogenetic interpretation is correct, a major question arises: how did the ancestors of Streblopus get to South America?

\section{Biogeography of Streblopus: a putative late-Cretaceous African origin for this South American genus}

To answer the question of how the ancestors of Streblopus got to South America, it is necessary to tackle two highly controversial issues in dung beetle evolutionary studies: the time of origin of the Scarabaeinae (and a subsequent time scale for the origin of the subfamily's different groups) and whether the distribution pattern shown by the major lineages of dung beetles across the southern continents is due to vicariance, dispersal or a combination of both factors. As will be argued, available evidence points to a late-Cretaceous African origin for the split between the lineages that gave rise to Streblopus and those from which Circellium and the Scarabaeini originated. Then, during the Upper Cretaceous or early Paleogene, the ancestor of Streblopus crossed the Atlantic Ocean from the West African coast and reached the South American east coast, most probably by rafting. During some time, the genus probably flourished across the tropical forest areas connecting the Atlantic Forest, its first area of colonization in South America, and Amazonia, but then, with the gradual advance of the South American Dry Diagonal during the last 25 million years, the forests retreated, the Atlantic Forest and Amazonia became isolated from one another by the open and dry environments of the Dry Diagonal, and Streblopus acquired its current relict distribution and diversity. 
Concerning the first controversial issue we have to deal with, namely the time of the origin of the Scarabaeinae, much has been published about this over the past decades (see Davis et al. 2002, 2017 and Davis 2009 for a thorough presentation of the debate). Tarasov \& Génier (2015) discussed the biogeography and the time of origin of the Scarabaeinae based on the topology of their phylogenetic tree and the distribution of its main lineages: according to them, their results support either a Cenozoic origin for the Scarabaeinae, with multiple intercontinental dispersal events explaining the lack of congruence between the phylogeny and the distribution of the taxa across the southern continents, or a Mesozoic origin for the dung beetles and the breakup of Gondwana as the vicariance event responsible for the observed distribution pattern. Arguing that the poor flight capacity of dung beetles would prevent them from crossing large oceanic distances, they championed a Mesozoic origin and vicariance as the most likely explanations.

Based on a Bayesian molecular phylogenetic analysis and molecular clock dating, and building on the biogeographical discussion by Tarasov \& Génier (2015), Gunter et al. (2016) proposed that the Scarabaeinae originated during the Upper Jurassic or Lower Cretaceous, sometime between 116 and 152 million years ago, and that a major radiation of dung beetle lineages occurred about 100 million years ago. Those findings, according to them, would fit a scenario where the origin of the current distribution pattern of many of the high-level lineages of dung beetles across the southern hemisphere continents was a consequence of both vicariance and dispersal from the African cradle of the group. Therefore, cases such as that of Streblopus, Circellium and Scarabaeini, where two Old World groups of African origin and a South American genus are closely related, could be explained either by the vicariance event represented by the complete separation of Africa from the rest of Gondwana that occurred about 115 million years ago (Heine et al. 2013) or through dispersal across the forming Atlantic Ocean. Dating the origin of the Streblopus + Circellium + Scarabaeini clade is, therefore, essential to answer this question.

Although Streblopus was not among the taxa studied by Gunter et al. (2016) ${ }^{2}$, their dating of the different internal nodes of the phylogeny of Scarabaeinae can illuminate our discussion. According to their estimates, the Scarabaeini appeared about 71 million years ago, and so this is the most recent limit for the separation between them and Streblopus. And what about the oldest limit? The origin of the crown-group of the node denominated as "Scarabaeinae B" by Gunter et al., which includes most of the dung beetles analyzed, was dated by them as being not older than 110 million years old, and most of their different calibration analyses dated it as being around 95 million years old (Gunter et al. 2016: table 6). That being so, the separation between Streblopus and Circellium and Scarabaeini occurred sometime between 95 and 71 million years ago, therefore between 20 and 45 million years after the final separation of Africa from Gondwana (Heine et al. 2013). Even if the oldest possible date for the origin of "Scarabaeinae B" is considered (i.e., 110 million years ago), that would still be 5 million years after the final breakup of the continents, and even if some few land connections still existed between Africa and South America during that period, it does not seem likely that Streblopus would have diverged from Circellium and Scarabaeini during that early period given that Tarasov \& Génier (2015) found the

\footnotetext{
${ }^{2}$ In their molecular investigation, Gunter et al. (2016: table 1) listed Circellium as one of taxa included in their molecular work. However, the genus was eventually excluded from their final analyses, probably due to the small number of markers available for it (Nicole Gunter, pers. comm. to MC, Sep. 2018). After an email exchange with MC, Gunter was kind enough to re-run her Bayesian analyses now including Circellium and, contrary to our expectation, she found the genus nested between Canthidium and Dichotomius, a hypothesized $~ 79-73$ millionyear-old New World clade, and therefore far apart from Scarabaeini. Curiously enough, of the three molecular analyses performed by Tarasov \& Dimitrov (2016), the only one that did not support a close relationship between Circellium and Scarabaeini is their Bayesian analysis; their two maximum likelihood analyses, on the other hand, recovered a Circellium + Scarabaeini clade in the same way as the morphological analyses of Philips et al. (2004a), Vaz-de-Mello (2007b) and Tarasov \& Génier (2015) had already done.
} 
CUPELLO M. et al., Systematics of Streblopus and dung beetle biogeography

clade Streblopus +Circellium + Scarabaeini deeply nested within the Scarabaeinae. It is worth noting that Forgie et al. (2006), in a phylogenetic analysis of the Scarabaeini criticized by Gunter et al. (2016) for its dating methods based upon published substitution rates for insects as a whole, hypothesized an even more recent origin for the tribe, about 9.8-23 million years ago in the Miocene. Were Forgie et al.'s results correct, then a mid-Cenozoic separation between Streblopus and Scarabaeini would be the most likely scenario. Also based on fixed substituion rates, the different datings of the dung beetle phylogeny by Davis et al. (2017) would also support an even more recent divergence between Streblopus and the Scarabaeini than in Gunter et al. (2016). Finally, it should be noted that the uncertain identity of the Cretaceous fossil Prionocephale deplanate Lin, 1980 as a true scarabaeine, which, as remarked by Tarasov \& Génier (2015), had already undermined a previous dating of the Scarabaeinae evolution (Ahrens et al. 2014), may also have impacted the results of Gunter et al. $(2016,2019)$ by overestimating the minimal age of the clade, for it was used to calibrate those works' molecular clocks. If this species is indeed not a scarabaeine, then the oldest known Scarabaeinae fossil would be Lobateuchus parisii Montreuil et al., 2010, from the French Eocene (Tarasov et al. 2016), which could support a later origin for the dung beetles.

Then, in conclusion, the most conservative hypothesis is that Streblopus diverged from the two most closely-related living lineages during the Upper Cretaceous, sometime between 95 and 71 million years ago. The ancestor of that group most probably lived in Africa, the continent where Circellium bacchus and the vast majority of the Scarabaeini still live; indeed, Africa is considered to be the ancestral area of the Scarabaeini (Davis et al. 2008; Scholtz 2009) and even of the subfamily as a whole (Monaghan et al. 2007; Sole \& Scholtz 2010; Gunter et al. 2016). But since Africa and South America have not been connected by land since the Lower Cretaceous (Heine et al. 2013), how could the ancestor of Streblopus have arrived in South America? The only option is through long-distance dispersal over the early South Atlantic Ocean.

As already discussed, Tarasov \& Génier (2015) argued that, due to the poor flight capacity of dung beetles, they would not be able to cross wide geographical barriers, particularly oceans, and establish new populations on the other side of the barrier. Nevertheless, the presence of two endemic genera on the oceanic island of Mauritius, on the Mascarene Islands (Davis 2009), about $1000 \mathrm{~km}$ from Madagascar, $2000 \mathrm{~km}$ from the coast of Southern Africa and, more importantly, $4000 \mathrm{~km}$ from India, where the closest relatives of the Mauritius endemic Nesosisyphus Vison, 1946 are today distributed (Vinson 1951), not only reveals that dung beetles do have the capacity to disperse across thousands of kilometres of oceanic waters, but also that they have actually done so at least twice over the past eight million years since the formation of Mauritius (Paul et al. 2007). ${ }^{3}$

\footnotetext{
${ }^{3}$ It is worth mentioning that Vinson (1951), in his revision of Nesosisyphus, doubted that the ancestors of the genus could have crossed the four-thousand-kilometre distance between India and Mauritius either by rafting or by flying. His argument against the first possibility was basically that he did not believe that those insects could have survived for months floating over the ocean without feeding, whereas the second possibility was ruled out invoking basically the same arguments as Tarasov \& Génier (2015) about the poor flight capability of dung beetles. Instead, Vinson elaborated what he called a "personal" and "not very orthodox" historical scenario for the formation of the Mascarenes, based on Alfred Wegener's theory of continental drift, where the archipelago was formed when the distance between the "African-Malagasy" and the Indian blocks was so short that the ancestors of Nesosisyphus would have been able to cross it regardless of their poor flight capabilities and food demands. Nevertheless, nowadays we know that the geological history of Mauritius and the other Mascarene islands was very different from the scenario proposed by Vinson (1951) and that India was basically at its current position when the volcanic activity that eventually formed Mauritius started about eight million years ago (Paul et al. 2007). Therefore, long-distance dispersal over the Indian Ocean is indeed the only possibility left to explain how the ancestors of Nesosisyphus and all other land organisms that live there got to the island.
} 
Therefore, the question is not whether dung beetles can or cannot disperse across oceanic barriers, but how frequently they have done so. An additional example of the (albeit limited) capability of dung beetles to cross sea barriers is their rich biogeographical history on the Caribbean Islands, with several independent invasions of the archipelago from different parts of the American continent (or even from Africa, as discussed in the Introduction) to most of the Greater and Lesser Antilles (Halffter \& Matthews 1966; Matthews 1966), with many groups showing evidence of taxon cycles (see the discussion of the different waves of immigration across the Antilles in Matthews 1966). Although a minor example, the record in Noriega (2002) of Digitonthophagus gazella (Fabricius, 1787) occurring on the Caribbean island of San Andrés (Colombia), about $200 \mathrm{~km}$ from the Central American coast, as early as 1995, just 24 years after the introduction of this African species to the American continent, shows that dung beetles can rapidly cross at least narrow sea barriers (if the species was not spread there by human means, of course).

The absence of dung beetles from many oceanic islands such as the Canary Islands, the Galapagos, Micronesia, most of Melanesia, and Hawaii and other Polynesian islands was invoked by Tarasov \& Génier (2015) to support their stance against long-distance dispersals as an explanation for the distribution pattern of Scarabaeinae across the southern continents. But the reason why it is inappropriate to compare the probability of a dung beetle dispersing between continents to a dispersal from a continent to an oceanic island is easily comprehensible when we take into account a combination of five factors, most of them tenets of the theory of island biogeography (MacArthur \& Wilson 1967): distance from mainland, size, isolation and age of the land mass (either an island or a continent), and availability of adequate food sources. Oceanic islands are smaller, more isolated from the continents and other biotic sources, including other archipelagos, and are younger than continents, which make them much more difficult to be colonized by any given organism than the much larger and older continents. While the first four factors mentioned above affect scarab beetles indiscriminately and explain much of the rarity of these insects on oceanic islands, dung beetles are particularly sensitive to the latter factor due to their very unusual feeding specialization on mammalian dung. Therefore, the islands need not only to be large enough to support the colonizing population of dung beetles, but also populations of mammals that will supply those beetles with the necessary food. This can be an explanation of why the Scarabaeinae were not able to establish new populations on a number of oceanic islands which other scarabaeoid groups of no better flight power were able to colonize (e.g., see the lists of scarabaeoid species on Hawaii (Nishida 2002; Paulsen \& Hawks 2014), Micronesia (Cartwright \& Gordon 1971), the Galapagos (Peck 2006; Ratcliffe 2014), Fernando de Noronha (Alvarenga 1962), the Canary Islands (Machado \& Oromí 2000), the Azores (Borges 1990) and the Mascarenes (Vinson 1958; Gomy 2000), among others. Landin (1963) considered that the entire scarabaeoid fauna of the Cape Verde Islands was introduced to the archipelago by human agency during the Modern Era, which may have been true also at least for Fernando de Noronha). Therefore, it is more surprising that the Scarabaeinae have been able to colonize the tiny and isolated Mauritius and there diversify in spite of its lack of an autochthonous mammalian fauna than their absence from archipelagos such as Hawaii and the Galapagos where no native land mammals have ever existed. Some authors have suggested that the Mauritius dung beetles originally fed primarily on bird dung, possibly even on dodo (Raphus cucullatus Linnaeus, 1758) droppings (Vinson 1951; Halffter \& Matthews 1966), but the two now-extinct giant Mauritius tortoises (i.e., Cylindraspis inepta Günther, 1873 and C. triserrata Günther, 1873) could have equally provided them with food.

But while oceanic islands are tiny, isolated and have no or very few native land mammals, continents are large, sustain rich mammalian communities and have long coasts that increase the chance of a castaway reaching them only by luck. Consequently, if dung beetles were able to colonize the tiny Mauritius from Africa, Madagascar or India, and probably reached other oceanic islands across the globe without being able to establish new populations there due to their lack of native terrestrial mammals (e.g., perhaps 
the Onthophagus in New Zealand; Gunter et al. 2019), some were probably capable of crossing the Atlantic Ocean and reaching South America, including the ancestor of Streblopus. Indeed, Cambefort (1991) has previously raised this same possibility for the origin of the ancestors of Phanaeini, and although the phylogenetic hypothesis he was building on (namely, that Phanaeini are closely related to the Onitini) does not find support in more recent studies, his dispersal hypothesis could be adapted to explain the origin in South America of the clade comprised of Phanaeini and other New World groups (viz, Dichotomiini and Eucraniini, based on Tarasov \& Génier 2015, or Dichotomiini, Eucraniini and Ateuchini, according to Tarasov \& Dimitrov 2016) that is either sister to a clade that includes Old World elements (Tarasov \& Dimitrov 2016) or is nested within a paraphylum of Old World distribution (Tarasov \& Génier 2015).

During its first stages of formation, the Atlantic Ocean was not too wide and, consequently, Africa and South America were not as far apart as presently (Heine et al. 2013). Therefore, the chances of a successful dispersal were higher than today, a possibility recognized by Tarasov \& Génier (2015) themselves in their 'relaxed' vicariance hypothesis. Many other groups of land and freshwater organisms are hypothesized to have crossed the Atlantic in either direction. Some of the most well-established examples among animals are the ancestors of the New World monkeys, Platyrrhini (e.g., Houle 1999; Schrago \& Russo 2003; Poux et al. 2006; de Oliveira et al. 2009; Silvestro et al. 2019), and those of the New World rodent taxon Caviomorpha (e.g., Poux et al. 2006; de Oliveira et al. 2009; Rowe et al. 2010; Voloch et al. 2013), which are thought to have crossed the Atlantic from Africa to South America during the Eocene/Oligocene. Among plants the most notable cases are those of Bromeliaceae and Rapateaceae (e.g., Givnish et al. 2004, 2007), a species of which crossed the Atlantic in the opposite direction during the Miocene. Besides these more well-known cases, a myriad of other biotic transatlantic dispersals have been proposed over the past few years, including cases of several families of plants (Renner 2004; Kistler et al. 2014) and animals such as hoatzins (Aves: Opisthocomiformes) (Mayr et al. 2011), Turdus Linnaeus, 1758 thrushes (Aves: Passeriformes) (Voelker et al. 2008), amphisbaenians (Reptilia: Squamata) (Vidal et al. 2008), Mabuya Fitzinger, 1826 skinks (Reptilia: Squamata) (Whiting et al. 2006), several groups of freshwater fishes (Actinopterygii: Teleostei) (Matschiner et al. 2017; Matschiner 2019) and insects like the ant-parasitoid wasp genus Kapala Cameron, 1884 (Hymenoptera: Eucharitidae) (Murray \& Heraty 2016) and the weevil tribe Anchonini (Coleoptera: Curculionidae) (Cristóvão \& Lyal 2018).

But how could all these organisms, most of them nonvolant or as poor fliers as dung beetles, successfully cross the Atlantic Ocean? Most of the authors who have dealt with cases of transatlantic dispersals have argued that the ancestors of different groups crossed the ocean through rafting or "floating islands" (Darlington 1957; Houle 1998; de Queiroz 2005), which means that the organisms were passively transported over water on floating pieces of land or tangled plant parts (the said rafts) detached from coastal areas or carried out to the sea from farther inland by rivers (Darlington 1957; Houle 1998, 1999; Oliveira et al. 2009). As put by Darlington (1957: 15), "[t] he objects may be more substantial than 'raft' suggests. When a flooded river undercuts its banks, brings down whole hillsides, and carries tangled masses of trees out to sea, many land animals may be taken along". If animals as big and physiologically demanding as rodents and monkeys could have been transported from the west coast of Africa to eastern South America on such rafts, then it is not difficult to imagine that a dung beetle could have survived for a relatively long period of time floating on a piece of tree or even on a small mass of soil as it crossed the Atlantic Ocean. Indeed, we do know that they have done something similar to that at least twice in their evolutionary history, for the ancestors of both Nesosisyphus and Nesovinsonia Martínez \& Pereira, 1959 most probably arrived on Mauritius on such floating islands, and, in fact, the same most likely occurred with the ancestors of the Malagasy dung beetle fauna (Orsini et al. 2007; Wirta et al. 2008; Wirta \& Montreuil 2008; Sole et al. 2011; Gunter et al. 2016) and is still probably occurring with the Caribbean dung beetles in their continuing dispersal across the West Indies. Moreover, as argued above, the Atlantic Ocean was much narrower during the Upper Cretaceous, when the ancestors of Streblopus 
possibly arrived in the New World; therefore, their voyage may have been much shorter than that of the mammals and most of the other organisms listed above that did not cross the Atlantic before the Cenozoic. Finally, wind and sea surface currents certainly acted to speed up the rafts towards South America; indeed, according to Renner (2004: S31), "equatorial currents can transport larger floating objects with wind-exposed surfaces across the Atlantic in less than 2 weeks", and that time was certainly even shorter in the narrower Upper Cretaceous Atlantic Ocean (Houle 1998).

\section{Conclusion}

One of the most enduring debates in evolutionary biology is certainly the one between those who favour dispersalist accounts for disjunct distributions of closely-related taxa versus those who champion hypotheses of barrier formation to explain why closely-related organisms are found apart. In summary, the former argue for dispersal over already-existing barriers, while the latter defend that distribution disjunctions are mostly the consequence of the formation of new barriers separating once-continuous populations into two or more geographical subunits. As with several other still-contentious issues in evolution, Charles Darwin (1809-1882) was one of the first to take part in this debate. His arguments with his close friend Sir Joseph Dalton Hooker (1817-1911) over the biogeographical history of the sub-Antarctic flora, with Darwin favouring dispersalist explanations for how continental plants arrived on the southern hemisphere islands, while Hooker invoked the past existence of hypothetical nowdisappeared land bridges connecting the southern continents to the Sub-Antarctic islands to explain that same distribution pattern (Browne 1995; Berry 2009), constituted some of the first debates from a Darwinian perspective in historical biogeography. Moreover, through his ingenious experiments in the 1850 s on the dispersal capacity of seeds, testing whether they could survive long periods on salt water, attached to birds' feathers and muddy legs, in the crops of dead birds or in the stomachs of dead fish, Darwin was one the first to ever attempt to demonstrate empirically that many organisms are able to cross long distances of adverse conditions and establish new populations beyond geographical barriers (Browne 1995). It is noteworthy that Darwin's final work was about how a particular water beetle, Dytiscus marginalis Linnaeus, 1758 (Coleoptera: Dytiscidae), could serve as a means of transport for bivalves attached to the beetle's appendices to disperse (Darwin 1882). ${ }^{4}$

This rich debate continued over the first century of the Darwinian evolutionary biology and the distribution patterns shown by different groups of organisms were given individual causal explanations. In doing so, the leading authors usually took into consideration both the fossil record of the organisms and the biological properties that increased or decreased their mobility and chances of dispersal (see Darlington 1957 for the epitome of that phase of biogeographical studies). If two or more closely related groups showing a disjunct distribution were known to have high dispersal capacity (e.g., small ballooning spiders) and a fossil record that did not predate the formation of the geographical barrier separating them, then dispersal hypotheses were preferred. In turn, distributional disjunctions between two or more closely-related taxa or populations of organisms with low mobility or with fossil records predating the formation of the barrier were preferably interpreted as a consequence of the division of an once-continuous population by the formation of that very barrier. The formation of insular biotas, in particular, was mostly explained by dispersal narratives, and the culmination of this research program

\footnotetext{
${ }^{4}$ It is likely that it was Darwin's own field observations of living land animals floating on open ocean while he was on board HMS Beagle that sparked his first ideas about the powers of long-distance dispersals. As noted in his journal (Darwin 1839: 159), among the animals Darwin saw in that condition were scarab beetles about $30 \mathrm{~km}$ ("seventeen miles") off the Atlantic coast of Argentina. Although that (or those) specimen(s) were identified by Darwin as belonging to Scarabaeus, that was almost certainly not the case, even in the broad 1830s application of the name. We failed to find any record of that material in Smith's catalogue of Darwin' insects, although other Coleoptera collected by Darwin on that occasion are, according to the catalogue, preserved in the BMNH (Smith 1987: 67, 73, entries 875, 1301-1303).
} 
CUPELLO M. et al., Systematics of Streblopus and dung beetle biogeography

was the elaboration of the theory of island biogeography in the 1960s (MacArthur \& Wilson 1963, 1967; see also Wilson 1994 and Quammen 1996 for a thorough historical account of the development of island biogeography). However, things would dramatically change that same decade, as the wide acceptance of the theory of plate tectonics and the demonstration that the configuration of the continents is anything but fixed led some biologists to extrapolate that organisms are mostly passive to changes in the landscape and, therefore, dispersal accounts were not only mostly unnecessary to explain distribution disjunctions, but most times they were simply "unscientific". That strong belief led some authors to misrepresent the work of past biogeographers with chauvinist statements such as that dispersal narratives in the Darwinian tradition "became a science of the improbable, the rare, the mysterious, and the miraculous" (Nelson 1978: 289), as if those biogeographers had not based their hypotheses on actual evidence based on the behaviour, morphology and fossil record of the organisms they were studying, as well as from geology and other physical aspects such as the ocean currents and wind movements of the areas involved (e.g., see Mayr \& Phelps 1967 for a meticulous and well-reasoned discussion of the biological and geological observations in favour of and against competing hypotheses for the origin of a bird fauna. Eventually, however, and possibly in recognition of the sense of simplicity and easy operationality that their oversimplified theory of biogeography offered, biogeographical evolutionary studies in the later decades of the $20^{\text {th }}$ century were heavily dominated by the vicariance biogeography of Nelson \& Rosen (1981) and Nelson \& Platnick (1981) and the panbiogeography of Croizat $(1958,1964)$ (see Hull 1988 and de Queiroz 2014 for more details on the historic development of these disciplines; for the sake of intellectual honesty, readers are also referred to Williams \& Ebach (2008) for this history from a alternative - though not supported here - perspective).

But if the 1960-1980s shift from the Darwinian tradition to a new orthodoxy where vicariance alone could account for much of the biotic distribution on Earth was a revolution in systematics, the last 20 years or so have been witnessing a counterrevolution, as eloquently put by de Queiroz (2005) more than a decade ago. With the growing application of increasingly sophisticated molecular techniques to date phylogenetic trees and speciation events, as well as with new fossil discoveries, more thorough morphological studies, and new interpretations of the geological history of continents and archipelagos, it has become clear that the formation of the disjunct distribution of many groups of organisms can only be explained by long-distance oceanic dispersals, since the formation of the oceanic barriers predate the evolutionary origin of those groups.

The large number of transatlantic dispersals discussed in the preceding paragraphs, including the case of Streblopus, are vivid examples of these new discoveries, and many further cases of dispersals across other oceans have been proposed (to mention just a few: Carranza et al. 2000; Briggs 2003; Yoder \& Nowak 2006; Kodandaramaiah \& Wahlberg 2007; Miraldo et al. 2011; Gillespie et al. 2012; de Queiroz 2014; Mitchell et al. 2014; Yonezawa et al. 2017; Kodandaramaiah et al. 2018; da Fonte et al. 2019; and the literature cited therein). Contrary to the allegations of many vicariance biogeographers that allude to dispersal events is a leap of faith and therefore "unscientific", Gillespie et al. (2012) have elegantly demonstrated how a sound knowledge of the physical and biological factors influencing the pace and direction of dispersal routes can help us to predict distributional patterns and understand why some groups have been able to colonize some lands whereas others have not. Oceanic dispersals, therefore, are not as random and rare as previously thought. After some decades of dominance of the vicariance model, a more pluralistic biogeography has emerged; as put by Simpson (1980: 253) almost four decades ago, "A reasonable biogeographer is neither a vicarist nor a dispersalist but an eclecticist".

And where does Streblopus stand after all that? The synthesis of our new morphological and distributional data with the emerging knowledge on the phylogenetic relationships of the high-level lineages of Scarabaeinae (Tarasov \& Génier 2015; Tarasov \& Dimitrov 2016) and the dating of this phylogenetic framework (Gunter et al. 2016) have shown that Streblopus is not a Deltochilini, as tentatively classified 
for more than a century. Instead it seems to be closely related to a lineage found exclusively outside the Americas and with a clear Southern African origin, the dung beetles of the genus Circellium and the tribe Scarabaeini, although it is unclear which of them Streblopus is more intimately associated with. Moreover, as there is evidence (Tarasov \& Génier 2015) that the clade Streblopus + Circellium + Scarabaeini is sister to another African clade, Chalconotus + Gyronotus, we propose that the branching off of the lineage that eventually led to Streblopus from its sister lineage (either Circellium, Scarabaeini or both) occurred in Africa sometime between 95 and 71 million years ago. This postdates the final separation of Africa from South America, which is thought to have happened about 115 million years ago (Heine et al. 2013). Since no land bridges are known to have existed after that period connecting the African continent to South America, the only possible explanation for the presence of Streblopus in the New World is through a transatlantic dispersal event that occurred most probably by rafting during the Upper Cretaceous or early Cenozoic (Fig. 29).

Although Tarasov \& Génier (2015) have favoured vicariance explanations for the distribution of the high-level lineages of dung beetles over the southern continents claiming that the alleged poor flight ability of dung beetles would prevent them from dispersing across long oceanic distances, we argue that the presence of two genera of Scarabaeinae on Mauritius not only demonstrates that dung beetles do have the capability to cross ocean barriers, but that they have done so at least twice in their evolutionary history. Their absence from other oceanic islands can be explained by a combination of factors. Chief among them - and unique to Scarabaeinae among most of the other scarab groups - is the lack on those islands of native land mammals and, consequently, of adequate food sources for the possible dispersers that manage to reach those islands, dispersers that, thereby, were not able to establish new populations. However, with their rich mammalian faunas, continents can potentially sustain new dung beetle colonizers that are able to reach them. Thus, taking into account the factors driving oceanic dispersals discussed by Gillespie et al. (2012), such as winds and ocean currents, the fact that the Atlantic Ocean was much narrower during the Upper Cretaceous and early Cenozoic than it is today, and the existence of numerous other examples of successful transatlantic dispersals performed by a plethora of organisms, including physiologically demanding mammals, it is not difficult to imagine that the ancestor of Streblopus was able to cross the Atlantic and reach the eastern coast of South America after floating for some weeks on a raft made of debris such as plant parts or masses of soil.

During interglacial periods of the Neogene, tropical forests flourished in central South America connecting the Atlantic Forest, on the eastern coast of the continent, to the Amazon Basin through numerous and vast forest corridors. Streblopus was then able to disperse from the Atlantic Forest to at least western Amazonia (Fig. 28). Later, however, the climate dried out and the forests retreated, giving space to the open environments of the South American Dry Diagonal. With the disappearance of the forest bridges connecting the Atlantic Forest to Amazonia, the populations of Streblopus in those two biomes became isolated from one another and have remained so ever since. Thus, the current distribution of the genus, limited to a small area in the central Atlantic Forest in the Brazilian states of Bahia and Espírito Santo and some sub-Andean Amazonian localities in Peru and Ecuador, is clearly relict.

Although very rare in collections over the $19^{\text {th }}$ and $20^{\text {th }}$ centuries, the number of specimens of Streblopus in museums has vastly increased over the past few years thanks to collecting efforts in areas where the genus occurs. These newly collected specimens allowed us to investigate the morphological diversity of the genus in a way that was impossible for previous authors who attempted to study the systematics of Streblopus (Van Lansberge 1874a; Balthasar 1938; Paulian 1939; Halffter \& Martínez 1966). We can confidently conclude that the Amazonian and the Atlantic Forest metapopulations are two independent species well characterized by a long list of morphological distinctions that we believe are good indicators that these metapopulations would not merge into a single one should they be in sympatry. In other words, they are full biological species. 
Both species show remarkable geographical variation. In Streblopus opatroides, the Atlantic Forest species, this variation is related to the ventral colouration. In the Amazonian species, S. punctatus, it concerns the presence or absence of umbilicate punctures on the ventral surface of the metatibiae. The causal factors for both cases of geographical variation are unknown to us. Finally, it was observed that both species have some remarkable secondary sexual characteristics, males bearing modified spurs and spines throughout the body. While it is clear that sexual selection plays a role in the evolution of those characters, how exactly it does so - e.g., acting during agonistic encounters between males for female access? - is still mysterious.

Though we have answered some of the questions posed by previous scarab specialists about the systematics of Streblopus, much still remains to be investigated. Besides the questions mentioned above about the ultimate (i.e., evolutionary) reasons for the geographical variations and sexual dimorphism shown by $S$. punctatus and $S$. opatroides, we still need to know in deeper detail how and when during the Neogene the genus dispersed from the Atlantic Forest to Amazonia, when the two current

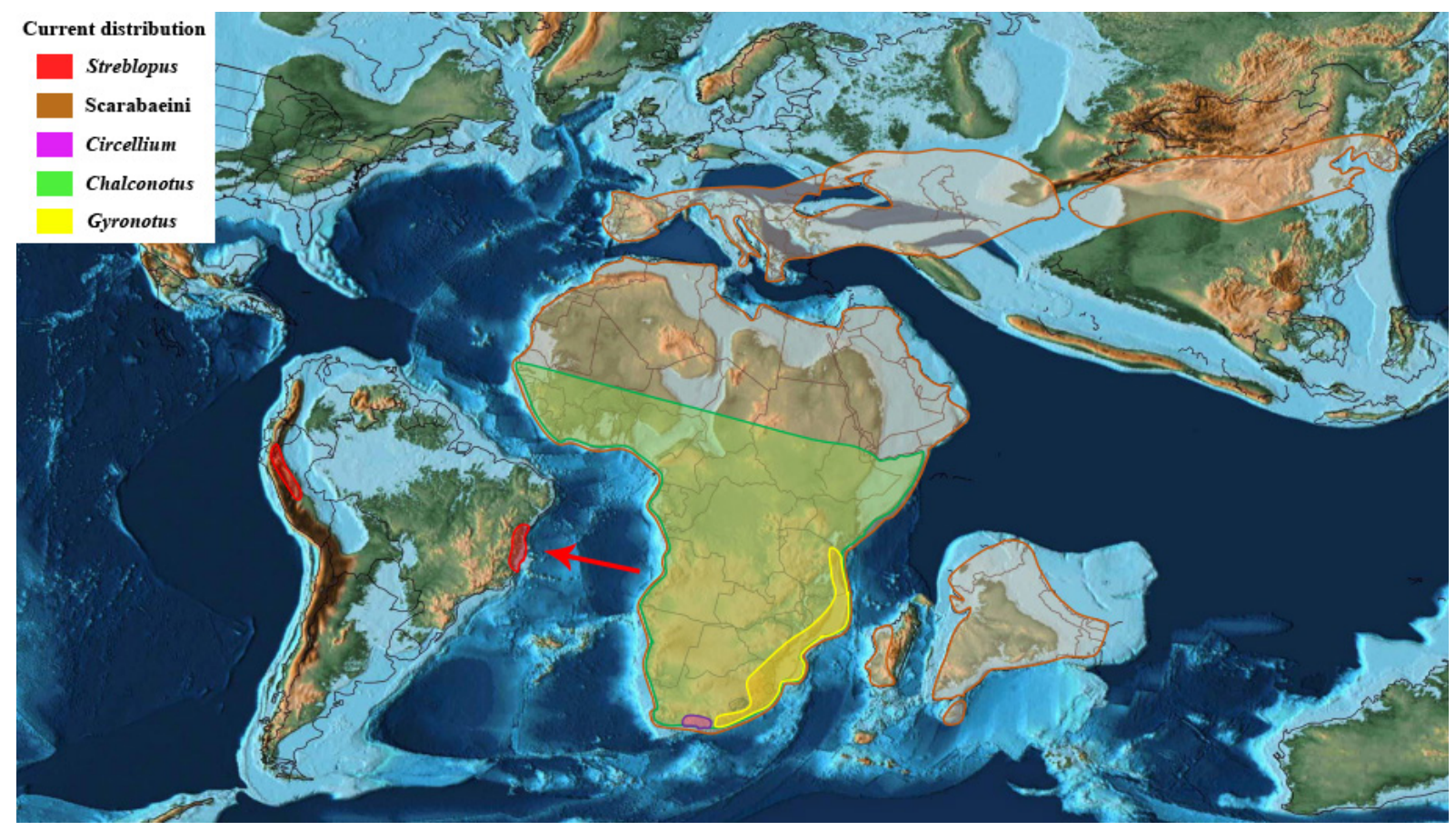

Fig. 29. Current distribution of Streblopus van Lansberge, 1874 and the Old World groups with which it is believed to be more closely related plotted on an Upper Cretaceous palaeomap ( $\sim 80$ million years ago). Based particularly on the hypothesis in Tarasov \& Génier (2015) that Streblopus is part of a clade otherwise composed uniquely of dung beetle lineages either exclusively distributed in Africa (Circellium, Chalconotus and Gyronotus) or with a distribution largely centred on that continent (Scarabaeini), and on the dating of the origin of the Scarabaeini as 71 million years ago (Gunter et al. 2016), we propose that the lineage that would eventually lead to Streblopus branched off from those groups in Africa some time between 95 and 71 million years ago, and that one of its descendent lineages (the only one living today) dispersed from its original continent to South America during the late Upper Cretaceous or the early Cenozoic. Since Africa and South America have not been connected by land since the Lower Cretaceous, the only way the ancestor of Streblopus could have reached South America was through transoceanic dispersal across the early South Atlantic. That dispersal probably happened by rafting on floating pieces of plants or other debris, as probably occurred with a large number of other organisms. Palaeomap modified from Scotese (2016); distribution area based on Balthasar (1963), Scholtz \& Howden (1987), Davis et al. (2008) and our own results. 
metapopulations became isolated from one another, and exactly when the divergence between the lineages that originated Streblopus and Circellium and/or Scarabaeini occurred during the $\sim 25$-millionyear timespan hypothesized above based on the molecular dating of the dung beetle phylogenetic tree of Gunter et al. (2016). Most of these questions can only be answered through molecular studies that include Streblopus, which has not yet happened, and this is certainly the next frontier to be explored with the genus. We hope, then, that our transatlantic dispersal hypothesis for the origin of Streblopus will not only help foster the development of the emerging pluralistic biogeography discussed above, but also that this view is applied to scarab beetle studies as a whole and that dispersal narratives will be considered more seriously by systematists studying the biogeography of Scarabaeinae.

\section{Acknowledgments}

We are grateful to the curators cited in the Material and Methods who received us during our visits to their institutions, to David Edmonds (Portland, Oregon, USA) for reviewing and correcting our illustrations of Streblopus mouthparts, to Luis Figueroa (MUSM) for sending us some valuable specimens of S. punctatus and for confirming our suspicions about the inaccuracy of the geographical records present in the literature for that species, to François Génier (CMNC) for sending label information of the specimens deposited at CMNC, to William Chamorro (Universidad Técnica Particular de Loja, Loja, Ecuador) for discussing some aspects of the distribution of S. punctatus with us, to Christopher R. Scotese (PALAEOMAP Project, Evanston, Illinois, USA) for dispelling our doubts regarding some of his palaeomaps, to Michael Geiser (BMNH) for translating Harold's passage on Colonychus, to Gabriel Nunes (CEMT) for the excellent dorsal photographs of $S$. opatroides illustrating this paper, to Ândrio Zafalon-Silva and Taxonline (DZUP) for the kind assistance with some of the photographs presented here, to Paul Schoolmeesters (Herent, Belgium) for providing us with literature, to Sergei Tarasov (Finnish Museum of Natural History, Helsinki, Finland) for discussing some phylogenetic and biogeographical issues with us, to Nicole Gunter (The Cleveland Museum of Natural History, Cleveland, Ohio, USA) for a deeply stimulating e-mail exchange on the evolution of dung beetles and for checking the positioning of Circellium in her molecular phylogenetic analyses, among several other issues, to Max Barclay (BMNH) for some helpful comments on the manuscript, and, finally, to two anonymous reviewers for their thoughtful comments and corrections. MC is supported by a $\mathrm{PhD}$ scholarship granted by the Brazilian Conselho Nacional de Desenvolvimento Científico e Tecnólogico (CNPq) and his museum visitis were partly funded by an Ernst Mayr Travel Grant (Museum of Comparative Zoology, Harvard University), a Canadian Museum of Nature Visiting Scientist Award and an Oxford University Museum of Natural History Visiting Fellowship. CSRC and FZVM are CNPq PQ1 fellows and FZVM was also financed by the following grants: CNPq 302997/2013-0, 484035/2013-4, 405697/2013-9, 440604/2015-0, 306745/2016-0; FAPEMAT/CNPq PRONEM 568005/2014; FAPEMAT 0147956/2014; Synthesys GB-TAF-3855; YSYEB, UMR 7205 CNRS/MNHN.

\section{References}

Ahrens D., Schwarzer J. \& Vogler A.P. 2014. The evolution of scarab beetles tracks the sequential rise of angiosperms and mammals. Proceedings of the Royal Society B 281 (1791): 1-10.

https://doi.org/10.1098/rspb.2014.1470

Alvarenga M. 1962. A entomofauna do arquipélago de Fernando de Noronha, Brasil - I. Arquivos do Museu Nacional 52: 21-25. Available from http:/www.museunacional.ufrj.br/publicacoes/wp-content/ arquivos/Arqs\%20v\%2052\%20p\%2021-25\%20Entomofauna,\%20Fernando\%20de\%20Noronha.pdf [accessed 7 Jan. 2020].

Anonymous. 2004. Nomenclator Zoologicus. Volumes 1-10. A List of the Names of the Genera and Subgenera in Zoology from the Tenth Edition of Linnaeus 1758 to the End of 2004. Neave S.A. (ed.) Ver. 0.86. Available from http://ubio.org/NomenclatorZoologicus/ [accessed 8 Sep. 2018]. 
CUPELLO M. et al., Systematics of Streblopus and dung beetle biogeography

Audino L.D., Louzada J. \& Comita L. 2014. Dung beetles as indicators of tropical forest restoration success: Is it possible to recover species and functional diversity? Biological Conservation 169: 248-257. https://doi.org/10.1016/j.biocon.2013.11.023

Balthasar V. 1938. Neue Gattungen und Arten der südamerikanischen Coprophagen. (4. Beitrag zur Kenntnis der Scarabaeiden der neotropischen Region). Entomologische Blätter 34 (4): 210-223.

Balthasar V. 1941. Scarabaeidae Laparostictae (Col.). Beitrage zur Fauna Perus 1: 337-358.

Balthasar V. 1951. Scarabaeidae Laparostictae (Col.). Beiträge zur Fauna Perus 2: 322-344.

Balthasar V. 1963. Monographie der Scarabaeidae und Aphodiidae der palaearktischen und orientalischen Region. Coleoptera: Lamellicornia. Band 1. Allgemeiner Teil. Systematischer Teil: 1. Scarabaeinae. 2. Coprinae (Pinotini, Coprini). Verlag der Tschechoslowakischen Akademie der Wissenschaften, Prague.

Barbero E., Palestrini C. \& Roggero A. 1998. Phylogenetic relationships in the genus Scarabaeus Linnaeus (Coleoptera, Scarabaeidae, Scarabaeinae). Memorie del Museo civico di Storia naturale di Verona 13: 87-96.

Batalha-Filho H., Fjeldså J., Fabre P.H. \& Miyaki C.Y. 2013. Connections between the Atlantic and the Amazonian forest avifaunas represent distinct historical events. Journal of Ornithology 154: 41-50. https://doi.org/10.1007/s10336-012-0866-7

Bateson W. 1894. Materials for the Study of Variation Treated with Especial Regard to Discontinuity in the Origin of Species. MacMillan and Co., London and New York.

Berry R.J. 2009. Hooker and islands. Biological Journal of the Linnean Society 96 (2): 462-481.

https://doi.org/10.1111/j.1095-8312.2008.01142.x

Beutel R.G. \& Lawrence J.F. 2005. Coleoptera, morphology. In: Beutel R.G. \& Leschen R.A.B. (eds) Coleoptera, Beetles. Volume 1: Morphology and Systematics (Archostemata, Adephaga, Myxophaga, Polyphaga partim). Handbuch der Zoologie: Eine Naturgeschichte der Stämme des Tierreiches. Band IV, Arthropoda: Insecta. Teilband 38: 23-28. Walter de Gruyter, Berlin and New York.

Bezděk A. \& Hájek J. 2011. Catalogue of type specimens of beetles (Coleoptera) deposited in the National Museum, Prague, Czech Republic. Scarabaeidae: Scarabaeinae: Ateuchini and Canthonini. Acta Entomologica Musei Nationalis Pragae 51 (1): 349-378.

Blackwelder R.E. 1944. Checklist of the coleopterous insects of Mexico, Central America, West Indies and South America. Part 2. United States National Museum Bulletin 185: 189-341.

https://doi.org/10.5479/si.03629236.185.2

Borges P.A.V. 1990. A checklist of the Coleoptera from the Azores with some systematic and biogeographic comments. Boletim do Museu Municipal do Funchal 42: 87-136.

Branco T. 2011. Scarabaeidae de l'Afrique de l'Ouest: les noms du niveau genre et leurs espèces types (Coleoptera). Catharsius 4: 9-25.

Briggs J.C. 2003. Fishes and birds: Gondwana life rafts reconsidered. Systematic Biology 52 (4): 548553. https://doi.org/10.1080/10635150390218385

Brown R.W. 1956. Composition of Scientific Words. A Manual of Methods and a Lexicon of Materials for the Practice of Logotechnics. Smithsonian Books, Washington DC.

Browne J. 1995. Charles Darwin: Voyaging. Jonathan Cape, London.

Cabanne G.S., Campagna L., Trujillo-Arias N., Naoki K., Gómez I., Miyaki C., Santos F.R., Dantas G.P.M., Aleixo A., Claramunt S., Rocha A., Caparroz R., Lovette I.J. \& Tubaro P.L. 2019. Phylogeographic variation within the buff-browed foliage-gleaner (Aves: Furnariidae: Syndactyla rufosuperciliata) 
supports an Andean-Atlantic forests connection via the Cerrado. Molecular Phylogenetics and Evolution 133: 198-213. https://doi.org/10.1016/j.ympev.2019.01.011

Cambefort Y. 1991. Biogeography and evolution. In: Hanski I. \& Cambefort Y. (eds) Dung Beetle Ecology: 51-67. Princeton University Press, Princeton, NJ.

Cartwright O.L. \& Gordon R.D. 1971. Coleoptera: Scarabaeidae. Insects of Micronesia 17 (4): 257-296.

Carranza S., Arnold E.N., Mateo J.A. \& López-Jurado L.F. 2000. Long-distance colonization and radiation in gekkonid lizards, Tarentola (Reptilia: Gekkonidae), revealed by mitochondrial DNA sequences. Proceedings of the Royal Society of London B 267: 637-649. https://doi.org/10.1098/rspb.2000.1050

Carvajal-López V. 2012. Primer registro de Streblopus punctatus Balthasar, 1938 y Dichotomius fonsecae (Luederwald [sic], 1925) (Coleoptera: Scarabaeidae) en las cordilleras del sur-oriente del Ecuador. Revista Politécnica 30 (3): 195-200.

Carvajal-López V., Villamarín S. \& Ortega A.M. 2011. Escarabajos del Ecuador. Principales Géneros. Instituto de Ciencias Biológicas, Escuela Politécnica Nacional, Quito.

Chamorro W., Marín-Armijos D., Granda V. \& Vaz-de-Mello F.Z. 2018. Listado de especies y clave de géneros y subgéneros de escarabajos estercoleros (Coleoptera: Scarabaeidae: Scarabaeinae) presentes y presuntos para Ecuador. Revista Colombiana de Entomología 44 (1): 72-100.

https://doi.org/10.25100/socolen.v44i1.6545

Chamorro W., Marín-Armijos D., Asenjo A. \& Vaz-de-Mello F.Z. 2019. Scarabaeinae dung beetles from Ecuador: a catalog, nomenclatural acts, and distribution records. Zookeys 826: 1-343. https://doi.org/10.3897/zookeys.826.26488

Costa L.P. 2003. The historical bridge between the Amazon and the Atlantic Forest of Brazil: a study of molecular phylogeography with small mammals. Journal of Biogeography 30: 71-86.

https://doi.org/10.1046/j.1365-2699.2003.00792.x

Croizat L. 1958. Panbiogeography. 3 volumes. Privately published, Caracas.

Croizat L. 1964. Space, Time, Form: The Biological Synthesis. Privately published, Caracas.

Cristóvão J.P. \& Lyal C.H.C. 2018. Anchonini in Africa: New species and genus confirming a transatlantic distribution (Coleoptera: Curculionidae: Molytinae). Diversity 10 (3): 1-34.

https://doi.org/10.3390/d10030082

Cupello M. \& Vaz-de-Mello F.Z. 2013a. New evidence for the validity of Coprophanaeus (C.) terrali Arnaud, 2002 (Coleoptera: Scarabaeidae: Scarabaeinae: Phanaeini), a dung beetle from Brazil. Zootaxa 3717 (3): 359-368. https://doi.org/10.11646/zootaxa.3717.3.5

Cupello M. \& Vaz-de-Mello F.Z. 2013b. Taxonomic revision of the South American dung beetle genus Gromphas Brullé, 1837 (Coleoptera: Scarabaeidae: Scarabaeinae: Phanaeini: Gromphadina). Zootaxa 3722 (4): 439-482. https://doi.org/10.11646/zootaxa.3722.4.2

Cupello M. \& Vaz-de-Mello F.Z. 2016. A new species and the phylogeny of the South American genus Gromphas Brullé, 1837 (Coleoptera: Scarabaeidae: Scarabaeinae: Phanaeini). Journal of Natural History 50 (15-16): 943-969. https://doi.org/10.1080/00222933.2015.1091099

Cupello M. \& Vaz-de-Mello F.Z. 2018. Monographic revision of the Neotropical dung beetle genus Sylvicanthon Halffter \& Martínez, 1977 (Coleoptera: Scarabaeidae: Scarabaeinae: Deltochilini), including a reappraisal of the taxonomic history of "Canthon sensu lato". European Journal of Taxonomy 467: 1-205. https://doi.org/10.5852/ejt.2018.467

Cupello M. \& Vaz-de-Mello F.Z. 2019. Case 3788 - Streblopus Lansberge, 1874 (Insecta, Coleoptera, Scarabaeidae): proposed conservation by suppression of Colonychus Harold, 1868. Bulletin of Zoological Nomenclature 76: 167-174. 
Daniel G.M., Davis A.L.V., Sole C.L. \& Scholtz C.H. 2018. Taxonomic review of the tribe Sisyphini sensu stricto Mulsant, 1842 (Coleoptera: Scarabaeidae: Scarabaeinae) in southern Africa, including new species descriptions. Insect Systematics \& Evolution (2018): 1-61. https://doi.org/10.1163/1876312X-00002195

Darlington P.J. Jr. 1957. Zoogeography: The Geographical Distribution of Animals. John Wiley \& Sons, New York.

Darwin C. 1839. Journal of Researches into the Geology and Natural History of the Various Countries Visited by H.M.S. Beagle, under the Command of Captain FitzRoy, R.N., from 1832 to 1836. Henry Colburn, London.

Darwin C. 1882. On the dispersal of freshwater bivalves. Nature 25: 529-530. https://doi.org/10.1038/025529f0

Davis A.L.V. 2009. Section D. Historical biogeography of the Scarabaeinae and its physical and biotic drivers. In: Scholtz C.H., Davis A.L.V. \& Kryger U. (eds) Evolutionary Biology and Conservation of Dung Beetles: 329-385. Pensoft Publishers, Sofia.

Davis A.L.V., Scholtz C.H. \& Philips T.K. 2002. Historical biogeography of scarabaeine dung beetles. Journal of Biogeography 29 (9): 1217-1256. https://doi.org/10.1046/j.1365-2699.2002.00776.x

Davis A.L.V., Frolov A.V. \& Scholtz C.H. 2008. The African Dung Beetle Genera. Protea Book House, Pretoria.

Davis A.L.V., Scholtz C.H. \& Sole C.L. 2017. Biogeographical and co-evolutionary origins of scarabaeine dung beetles: Mesozoic vicariance versus Cenozoic dispersal and dinosaur versus mammal dung. Biological Journal of the Linnean Society 120 (2): 258-273. https://doi.org/10.1111/bij.12893

Dellacasa D., Dellacasa M. \& Mann D.J. 2010. The morphology of the labrum (epipharynx, ikrioma and aboral surface) of adult Aphodiini (Coleoptera: Scarabaeidae: Aphodiinae), and its implications for systematics. Insecta Mundi 132: 1-21.

Edmonds W.D. 1972. Comparative skeletal morphology, systematics and evolution of the phanaeine dung beetles (Coleoptera: Scarabaeidae). The University of Kansas Science Bulletin 49: 731-874 Available from http://biodiversitylibrary.org/page/4385744 [accessed 7 Jan. 2020].

Edmonds W.D. 1994. Revision of Phanaeus MacLeay, a New World genus of Scarabaeinae dung beetles (Coleoptera: Scarabaeidae, Scarabaeinae). Natural History Museum of Los Angeles County Contributions in Science 443: 1-105. Available from http://biodiversitylibrary.org/page/52114491 [accessed 7 Jan. 2020].

Edmonds W.D. \& Zídek J. 2010. A taxonomic review of the Neotropical genus Coprophanaeus Olsoufieff, 1924 (Coleoptera: Scarabaeidae, Scarabaeinae). Insecta Mundi 129: 1-111.

Edmonds W.D. \& Zídek J. 2012. Taxonomy of Phanaeus revisited: revised keys to and comments on species of the New World dung beetle genus Phanaeus MacLeay, 1819 (Coleoptera: Scarabaeidae: Scarabaeinae: Phanaeini). Insecta Mundi 274: 1-108.

Emlen D.J. \& Philips T.K. 2006. Phylogenetic evidence for an association between tunneling behavior and the evolution of horns in dung beetles (Coleoptera: Scarabaeidae: Scarabaeinae). Coleopterists Society Monograph 5: 47-56.

Feer F. \& Pincebourde S. 2005. Diel flight activity and ecological segregation within an assemblage of tropical forest dung and carrion beetles. Journal of Tropical Ecology 21 (1): 21-30.

https://doi.org/10.1017/S0266467404002056

Ferreira M.C. 1972. Os escarabídeos de África (Sul do Sáara). I. Revista de Entomologia de Moçambique 11: 5-1088. 
da Fonte L.F.M., Mayer M. \& Lötters S. 2019. Long-distance dispersal in amphibians. Frontiers of Biogeography 11 (4): e44577. https://doi.org/10.21425/F5FBG44577

Forgie S.A., Philips T.K. \& Scholtz C.H. 2005. Evolution of the Scarabaeini (Scarabaeidae: Scarabaeinae). Systematic Entomology 30: 60-96. https://doi.org/10.1111/j.1365-3113.2004.00273.x

Forgie S.A., Kryger U., Bloomer P. \& Scholtz C.H. 2006. Evolutionary relationships among the Scarabaeini (Coleoptera: Scarabaeidae) based on combined molecular and morphological data. Molecular Phylogenetics and Evolution 40: 662-678. https://doi.org/10.1016/j.ympev.2006.04.018

França F.M., Silva F.A.B., Souza J.G.M., Grossi P.C. \& Vaz-de-Mello F.Z. 2012. New distributional data on Oxysternon pteroderum Nevison [sic], 1892 (Scarabaeidae, Scarabaeinae, Phanaeini) and its possible implications in conservation. Zookeys 174: 1-6. https://doi.org/10.3897/zookeys.174.2659

Gemminger M. 1870. Catalogus Coleopterorum hucusque Descriptorum Synonymicus et Systematicus. Vol. VII. Tenebrionidae, Nilionidae, Pythidae, Melandryidae, Lagriidae, Pedilidae, Anthicidae, Pyrochroidae, Mordellidae, Rhipidophoridae, Cantharidae, Oedemeridae. E.H. Gummi, Munich. Available from https://biodiversitylibrary.org/page/9650994 [accessed 7 Jan. 2020].

Génier F. 1996. A revision of the Neotropical genus Ontherus Erichson (Coleoptera: Scarabaeidae: Scarabaeinae). Memoirs of the Entomological Society of Canada 170: 1-169.

Génier F. 2009. Le genre Eurysternus Dalman, 1824 (Scarabaeidae: Scarabaeinae: Oniticellini), Révision taxonomique et Clés de Détermination illustrées. Pensoft, Sofia and Moscow.

Gillespie R.G., Baldwin B.G., Waters J.M., Fraser C.I., Nikula R. \& Roderick G.K. 2012. Long-distance dispersal: A framework for hypothesis testing. Trends in Ecology and Evolution 27 (1): 47-56.

https://doi.org/10.1016/j.tree.2011.08.009

Gillet J.J.E. 1911. Coleopterorum Catalogus. Pars 38: Scarabaeidae: Coprinae I. W. Junk, Berlin.

Givnish T.J., Millam K.C., Evans T.M., Hall J.C., Pires J.C., Berry P.E. \& Sytsma K.J. 2004. Ancient vicariance or recent long-distance dispersal? Inferences about phylogeny and South American-African disjunctions in Rapateaceae and Bromeliaceae based on $n d h \mathrm{~F}$ sequence data. International Journal of Plant Sciences 165 (Suppl. 4): S35-S54. https://doi.org/10.1086/421067

Givnish T.J., Millam K.C., Berry P.E. \& Sytsma K.J. 2007. Phylogeny, adaptative radiation, and historical biogeography of Bromeliaceae inferred from $n d h \mathrm{~F}$ sequence data. Aliso 23 (1): 3-26.

Gomy Y. 2000. Nouvelle Liste chronologique des Coléoptères de l'Archipel des Mascareignes. Société Réunionnaise des Amis du Muséum, Saint-Denis, France.

Gunter N.L., Weir T.A., Slipinski A., Bocak L. \& Cameron S.L. 2016. If dung beetles (Scarabaeidae: Scarabaeinae) arose in association with dinosaurs, did they also suffer a mass co-extinction at the K-Pg boundary? PLoS One 11 (5): 1-47. https://doi.org/10.1371/journal.pone.0153570

Gunter N.L., Monteith G.B., Cameron S.L. \& Weir T.A. 2019. Evidence from Australian mesic zone dung beetles supports their Gondwanan origin and Mesozoic diversification of the Scarabaeinae. Insect Systematics \& Evolution 50 (2): 162-188. https://doi.org/10.1163/1876312X-00002171

Halffter G. 1952. Notas sobre el género Phanaeus. I. Phanaeus quadridens Say, 1835 (Col., Scarab.). Ciencia 12 (3-4): 79-86.

Halffter G. 1955. Notas sobre el género Phanaeus. II. Phanaeus martinezi nov. sp. Revista de la Sociedad Mexicana de Entomología 1 (1-2): 73-84.

Halffter G. 1961. Monografia de las especies norteamericanas del género Canthon Hoffsg. (Coleopt., Scarab.). Ciencia, Revista Hispano-Americana de Ciencias Puras y Aplicadas 20 (9-12): 225-320.

Halffter G. 1974. Eléments anciens de l'entomofaune néotropicale: ses implications biogéographiques. Quaestiones Entomologicae 10: 223-262. 
Halffter G. 2003. Tribu Scarabaeini, subtribu Canthonina. In: Morón M.A. (ed.) Atlas de los Escarabajos de México. Coleoptera: Lamellicornia. Vol. II. Familias Scarabaeidae, Trogidae, Passalidae y Lucanidae: 21-43. Argania Editio, Barcelona.

Halffter G. \& Edmonds W.D. 1982. The Nesting Behavior of Dung Beetles (Scarabaeinae). An Ecological and Evolutive Approach. Instituto de Ecología, Mexico DF.

Halffter G. \& Martínez A. 1966. Revision monográfica de los Canthonina americanos (Coleoptera, Scarabaeidae) (I ${ }^{\mathrm{a}}$ Parte). Revista de la Sociedad Mexicana de Historia Natural 27: 89-177.

Halffter G. \& Martínez A. 1967. Revision monográfica de los Canthonina americanos (Coleoptera, Scarabaeidae) (2a Parte). Revista de la Sociedad mexicana de Historia natural 28: 79-117.

Halffter G. \& Martínez A. 1968. Revision monográfica de los Canthonina americanos (Coleoptera,

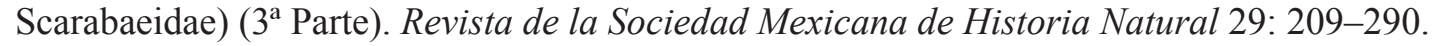

Halffter G. \& Martínez A. 1977. Revisión monográfica de los Canthonina americanos, IV parte. Clave para géneros y subgéneros. Folia Entomológica Mexicana 38: 29-107.

Halffter G. \& Matthews E.G. 1966. The natural history of dung beetles of the subfamily Scarabaeinae (Coleoptera: Scarabaeidae). Folia Entomológica Mexicana 12-14: 1-312.

Hanski I. \& Cambefort Y. 1991. Dung Beetle Ecology. Princeton University Press, Princeton, NJ.

Harold E. 1868. Monographie der Gattung Canthon. Berliner entomologische Zeitschrift 12: 1-144. https://doi.org/10.1002/mmnd.18680120104

Harold E. 1869. Catalogus Coleopterorum. Hucusque Descriptorum, Synonymicus et Systematicus. Vol. IV. Scarabaeidae: 979-1346. E.H. Gummi, Munich.

Available from http://biodiversitylibrary.org/page/9641549 [accessed 7 Jan. 2020].

Heine C., Zoethout J. \& Müller R.D. 2013. Kinematics of the South Atlantic rift. Solid Earth 4: 215253. https://doi.org/10.5194/se-4-215-2013

Hernández M.I.M. 2002. The night and day of dung beetles (Coleoptera, Scarabaeidae) in the Serra do Japi, Brazil: elytra colour related to daily activity. Revista brasileira de Entomologia 46 (4): 597-600.

Horgan F.G. 2005a. Aggregated distribution of resources creates competition refuges for rainforest dung beetles. Ecography 28: 603-618. https://doi.org/10.1111/j.2005.0906-7590.04177.x

Horgan F.G. 2005b. Effects of deforestation on diversity, biomass and function of dung beetles on the eastern slopes of the Peruvian Andes. Forest Ecology and Management 216: 117-133.

https://doi.org/10.1016/j.foreco.2005.05.049

Horgan F.G. 2006. Aggregation and coexistence of dung beetles in montane rain forest and deforested sites in central Peru. Journal of Tropical Ecology 22: 359-370.

Horgan F.G. 2009. Invasion and retreat: shifting assemblages of dung beetles amidst changing agricultural landscapes in central Peru. Biodiversity and Conservation 18: 3519-3541.

https://doi.org/10.1007/s10531-009-9658-7

Horn W., Kahle I., Friese G. \& Gaedike R. 1990a. Collectiones Entomologicae. Ein Kompendium über den Verbleib entomologischer Sammlungen der Welt bis 1960. Teil I: A bis K. Akademie der Landwirtschaftswissenschaften der Deutschen Demokratischen Republik, Berlin.

Horn W., Kahle I., Friese G. \& Gaedike R. 1990b. Collectiones Entomologicae. Ein Kompendium über den Verbleib entomologischer Sammlungen der Welt bis 1960. Teil II: L bis Z. Akademie der Landwirtschaftswissenschaften der Deutschen Demokratischen Republik, Berlin.

Houle A. 1998. Floating islands: a mode of long-distance dispersal from small and medium-sized terrestrial vertebrates. Diversity and Distributions 4: 201-216. 
Houle A. 1999. The origin of Platyrrhines: An evaluation of the Antarctic scenario and the floating island model. American Journal of Physical Anthropology 109 (4): 541-559.

https://doi.org/10.1002/(SICI)1096-8644(199908)109:4<541::AID-AJPA9>3.0.CO;2-N

Howden H.F. 1971. Five unusual genera of New World Scarabaeidae (Coleoptera). The Canadian Entomologist 103 (10): 1463-1471. https://doi.org/10.4039/Ent1031463-10

Howden H.F. 1976. New species in the genera Bdelyropsis, Cryptocanthon and Drepanocerus (Coleoptera: Scarabaeidae). Proceedings of the Entomological Society of Washington 78 (1): 95-103.

Howden H.F., Cartwright O.L. \& Halffter G. 1956. Descripción de una nueva especie mexicana de Onthophagus con anotaciones ecológicas sobre especies asociadas a nidos de animales y a cuevas. Acta Zoologica Mexicana 1 (9): 1-16.

Hull D.L. 1988. Science as a Process. An Evolutionary Account of the Social and Conceptual Development of Science. The University of Chicago Press, Chicago and London.

ICZN [International Commission on Zoological Nomenclature] 1999. International Code of Zoological Nomenclature. Fourth edition. International Trust for Zoological Nomenclature, London. Available from http://www.nhm.ac.uk/hosted-sites/iczn/code/ [accessed 7 Jan. 2020].

Karsch F. 1887. Altes und neues über Koleopteren. Berliner entomologische Zeitschrift 31: 1-8.

Kistler L., Montenegro Á., Smith B.D., Gifford J.A., Green R.E., Newsom L.A. \& Shapiro B. 2014. Transoceanic drift and the domestication of African bottle gourds in the Americas. Proceedings of the National Academy of Sciences 111 (8): 2937-2941. https://doi.org/10.1073/pnas.1318678111

Kodandaramaiah U. \& Wahlberg N. 2007. Out-of-Africa origin and dispersal-mediated diversification of the butterfly genus Junonia (Nymphalidae: Nymphalinae). Journal of Evolutionary Biology 20 (6): 2181-2191. https://doi.org/10.1111/j.1420-9101.2007.01425.x

Kodandaramaiah U., Braby M.F., Grund R., Müller C.J. \& Wahlberg N. 2018. Phylogenetic relationships, biogeography and diversification of Coenonymphina butterflies (Nymphalidae: Satyrinae): intercontinental dispersal of a southern Gondwanan group? Systematic Entomology 43 (4): 798-809. https://doi.org/10.1111/syen.12303

Kohlmann B. 1981. Nuevas especies de Ateuchus de México (Coleoptera: Scarabaeidae). Folia Entomologica Mexicana 49: 71-92.

Kohlmann B. 1984. Biosistemática de las especies norteamericanas del género Ateuchus (Coleoptera: Scarabaeidae: Scarabaeinae). Folia Entomológica Mexicana 60: 3-81.

Kolbe H.J. 1905. Über die Lebensweise und die geographische Verbreitung der coprophagen Lamellicornier. Zoologischen Jahrbücher, Supplement 8: 475-594.

Kolbe H.[J.] 1907. Hamburger Magalhaensische Sammelreise. Coleopteren. L. Friederichsen \& Co., Hamburg.

Krajcik M. 2006. Checklist of Scarabaeoidea of the World. 1. Scarabaeinae (Coleoptera: Scarabaeidae: Scarabaeinae). Animma 3 (Suppl. X): 1-189.

Krajcik M. 2012. Checklist of the World Scarabaeoidea. Animma.X, Supplement 5: 1-278.

Krell F.-T. 1992. Verschmelzung von Antennomeren (Symphysocerie) als Regelfall bei Temnorhynchus repandus Burmeister, 1847, sowie phylogenetische, taxonomische, faunistische und nomenklaturische Anmerkungen zu diversen Taxa dieser Gattung (Coleoptera. Scarabaeoidea, Melolonthidae, Dynastinae, Pentodontini). Deutsche Entomologische Zeitschrift 39 (4-5): 295-367. https://doi.org/10.1002/mmnd.19920390408

Kukalovà-Peck J. \& Lawrence J.F. 1993. Evolution of the hind wing in Coleoptera. The Canadian Entomologist 125: 181-258. https://doi.org/10.4039/Ent125181-2 
CUPELLO M. et al., Systematics of Streblopus and dung beetle biogeography

Kukalovà-Peck J. \& Lawrence J.F. 2004. Relationships among coleopteran suborders and major endoneopteran lineages: Evidence from hind wing characters. European Journal of Entomology 101: 95-144. https://doi.org/10.14411/eje.2004.018

Landin B.-O. 1963. The lamellicorn beetles of the Cape Verde Islands with some biogeographical aspects. Commentationes Biologicae 26: 1-26.

Lawrence J.F., Beutel R.G., Leschen R.A.B. \& Ślipiński A. 2010. Glossary of morphological terms. In: Leschen R.A.B., Beutel R.G. \& Lawrence J.F. (eds) Coleoptera, Beetles. Volume 2: Morphology and Systematics (Elateroidea, Bostrichiformia, Cucujiformia partim). Handbook of Zoology. Arthropoda: Insecta: 9-20. Walter de Gruyter, Berlin and New York.

Ledo R.M.D. \& Colli G.R. 2017. The historical connections between the Amazon and the Atlantic Forest revisited. Journal of Biogeography 44 (11): 2551-2563. https://doi.org/10.1111/jbi.13049

López-Guerrero Y. \& Halffter G. 2000. Evolution of the spermatheca in the Scarabaeoidea (Coleoptera). Fragmenta Entomologica 32: 225-285.

Lucas R. 1920. Catalogus Alphabeticus Generum et Subgenerum Coleopterorum Orbis Terrarum Totius (Famil., Trib., Subtr., Sect. incl.). Pars I. Nicolaische Verlags-Buchhandlung, Berlin.

MacArthur R.H. \& Wilson E.O. 1963. An equilibrium theory of insular zoogeography. Evolution 17 (4): 373-387. https://doi.org/10.2307/2407089

MacArthur R.H. \& Wilson E.O. 1967. The Theory of Island Biogeography. Princeton University Press, Princeton, NJ.

Machado A. \& Oromí P. 2000. Elenco de los coleópteros de las Islas Canarias. Instituto de Estudios Canarios, La Laguna, Spain.

Maldaner M.E., Nunes R.V. \& Vaz-de-Mello F.Z. 2015. Taxonomic revision of the Dichotomius speciosus (Waterhouse, 1891) species group (Coleoptera: Scarabaeidae: Scarabaeinae). Zootaxa 3986: 549-560. https://doi.org/10.11646/zootaxa.3986.5.2

Maldaner M.E., Vaz-de-Mello F.Z., Takiya D.M. \& Ferreira D.C. 2018. Molecular phylogeny of Coprophanaeus (Megaphanaeus) d'Olsoufieff, 1924 (Coleoptera: Scarabaeidae: Scarabaeinae) and the position of C. bellicosus. Insect Systematics \& Evolution (2018): 1-15.

https://doi.org/10.1163/1876312X-00002198

Martínez A. \& Halffter G. 1972. New taxa of American Canthonina (Coleoptera, Scarabaeinae). Entomologische Arbeiten aus dem Museum G. Frey 23: 33-66.

Available from http://biodiversitylibrary.org/page/45978703 [accessed 22 Jan. 2020].

Martínez A. \& Pereira F.S. 1967. Notas escarabeidológicas III (Col. Scarabaeidae-Scarabaeinae). Revista de la Sociedad Entomológica Argentina 29: 53-69.

Matschiner M. 2019. Gondwanan vicariance or trans-Atlantic dispersal of cichlid fishes: a review of the molecular evidence. Hydrobiologia 832: 9-37. https://doi.org/10.1007/s10750-018-3686-9

Matschiner M., Musilová Z., Barth J.M.I., Starostová Z., Salzburger W., Steel M. \& Bouckaert R. 2017. Bayesian phylogenetic estimation of clade ages supports trans-Atlantic dispersal of cichlid fishes. Systematic Biology 66 (1): 3-22. https://doi.org/10.1093/sysbio/syw076

Matsuda R. 1965. Morphology and evolution of the insect head. Memoirs of the American Entomological Institute 4: 1-334.

Matthews E.G. 1966. A taxonomic and zoogeographic survey of the Scarabaeinae of the Antilles (Coleoptera: Scarabaeidae). Memoirs of the American Entomological Society 21: 1-134. Available from http://biodiversitylibrary.org/page/38924033 [accessed 7 Jan. 2020]. 
Matthews E.G. 1971. [Book review of "Revision Monográfica de los Canthonina, Parts I, II, and III. Gonzalo Halffter and Antonio Martinez"]. The Coleopterists Bulletin 25 (2): 47-50.

Matthews E.G. 1974. A revision of the scarabaeine dung beetles of Australia. II. Tribe Scarabaeini. Australian Journal of Zoology, Supplementary Series 24: 1-211. https://doi.org/10.1071/AJZS024

Mayr E. 1940. Speciation phenomena in birds. The American Naturalist 74 (752): 249-278.

https://doi.org/10.1086/280892

Mayr E. 1942. Systematics and the Origin of Species from the Viewpoint of a Zoologist. Harvard University Press, Cambridge, MA.

Mayr E. 1963. Animal Species and Evolution. The Belknap Press of Harvard University Press, Cambridge, MA.

Mayr E. 1970. Populations, Species, and Evolution. An Abridgment of "Animal Species and Evolution”. The Belknap Press of Harvard University Press, Cambridge, MA.

Mayr E. 1996. What is a species, and what is not? Philosophy of Science 63 (2): 262-277.

Mayr E. \& Phelps W.H. Jr. 1967. The origin of the bird fauna of the South Venezuelan highlands. Bulletin of the American Museum of Natural History 136 (5): 269-328.

Mayr G., Alvarenga H. \& Mourer-Chauviré C. 2011. Out of Africa: Fossils shed light on the origin of the hoatzin, an iconic Neotropic bird. Naturwissenschaften 98: 961-966.

https://doi.org/10.1007/s00114-011-0849-1

Medina C.A. \& Scholtz C.H. 2005. Systematics of the southern African genus Epirinus Reiche (Coleoptera: Scarabaeinae: Canthonini): descriptions of a new species and phylogeny. Insect Systematics and Evolution 36: 145-160. https://doi.org/10.1163/187631205788838500

Medina C.A., Molano F. \& Scholtz C.H. 2013. Morphology and terminology of dung beetles (Coleoptera: Scarabaeidae: Scarabaeinae) male genitalia. Zootaxa 3626: 455-476.

https://doi.org/10.11646/zootaxa.3626.4.3

Medina-Uribe C.A. 2015. Canthonini (Scarabaeidae: Scarabaeinae) of Gondwana: Comparison of Male Genitalia, Evolutionary Trends and Phylogeny. $\mathrm{PhD}$ thesis, University of Pretoria, Pretoria.

Melo G.A.R., Faria L.R.R. \& Santos L.M. 2019. Xenochlora meridionalis sp. nov. (Hymenoptera: Apidae), a new halictine bee from eastern Brazil as evidence of past connections between Amazonia and Atlantic Forest. Zoologia 36: 1-7. https://doi.org/10.3897/zoologia.36.e33805

Minelli A. 2004. A segmental analysis of the beetle antenna. Studi Trentini di Scienze Naturali, Acta Biologica 81: 91-101.

Minelli A. 2017. The insect antenna: segmentation, patterning and positional homology. Journal of Entomological and Aracological Research 49: 59-66.

Miraldo A., Wirta H. \& Hanski I. 2011. Origin and diversification of dung beetles in Madagascar. Insects 2: 112-127. https://doi.org/10.3390/insects2020112

Mitchell K.J., Llamas B., Soubrier J., Rawlence N.J., Worthy T.H., Wood J., Lee M.S.Y. \& Cooper A. 2014. Ancient DNA reveals elephant birds and kiwi are sister taxa and clarifies ratite bird evolution. Science 344 (6186): 898-900. https://doi.org/10.1126/science.1251981

Molano-Rendón F. \& Medina-Uribe C.A. 2010. Especie nueva de Scybalocanthon (Coleoptera: Scarabaeinae: Canthonini) y descripción de la variación del órgano genital masculino. Revista mexicana de Biodiversidad 81: 689-699. https://doi.org/10.22201/ib.20078706e.2010.003.640 
CUPELLO M. et al., Systematics of Streblopus and dung beetle biogeography

Monaghan M.T., Inward D.J.G., Hunt T. \& Vogler A.F. 2007. A molecular phylogenetic analysis of the Scarabaeinae (dung beetles). Molecular Phylogenetics and Evolution 45: 674-692.

https://doi.org/10.1016/j.ympev.2007.06.009

Montreuil O. 2010. Première espèce du genre Haroldius Boucomont, 1914, à Madagascar, et redéfinition des Epilissini (Coleoptera, Scarabaeidae, Ateuchini). Bulletin de la Société entomologique de France 115 (1): 73-76.

Murray E.A. \& Heraty J.M. 2016. Invading Africa: A novel transoceanic dispersal by a New World ant parasitoid. Journal of Biogeography 43 (9): 1750-1761. https://doi.org/10.1111/jbi.12789

Nelson G. 1978. From Candolle to Croizat: Comments on the history of biogeography. Journal of Historical Biology 11: 269-305.

Nelson G. \& Platnick N.I. 1981. Systematics and Biogeography: Cladistics and Vicariance. Columbia University Press, New York.

Nelson G. \& Rosen D.E. 1981. Vicariance biogeography: A critique. Columbia University Press, New York, New York, 593 pp.

Nishida G.M. 2002. Hawaiian terrestrial arthropod checklist. Fourth edition. Bishop Museum Technical Report 22: 1-313.

Noriega J.A. 2002. First report of the presence of the genus Digitonthophagus (Coleoptera: Scarabaeidae) in Colombia. Caldasia 24 (1): 213-2015.

Nunes L.G.O.A., Nunes R.V. \& Vaz-de-Mello F.Z. 2018. Taxonomic revision of the South American subgenus Canthon (Goniocanthon) Pereira \& Martínez, 1956 (Coleoptera: Scarabaeidae: Scarabaeinae: Deltochilini). European Journal of Taxonomy 437: 1-31. https://doi.org/10.5852/ejt.2018.437

Nunes L.G.O.A., Nunes R.V. \& Vaz-de-Mello F.Z. 2020. Taxonomic revision of the South American subgenus Canthon (Peltecanthon) Pereira, 1953 (Coleoptera: Scarabaeidae: Scarabaeinae: Deltochilini). European Journal of Taxonomy 594: 1-27. https://doi.org/10.5852/ejt.2020.594

Nunes R.V. \& Vaz-de-Mello F.Z. 2019. Taxonomic revision of Dichotomius (Cephagonus) Luederwaldt 1929 and the taxonomic status of remaining Dichotomius Hope, 1838 subgenera (Coleoptera: Scarabaeidae: Carabaeinae: Dichotomiini). Journal of Natural History 53 (37-38): 2231-2351.

https://doi.org/10.1080/00222933.2019.1692088

de Oliveira F.B., Molina E.C. \& Marroig G. 2009. Paleogeography of the South Atlantic: A route for primates and rodents into the New World? In: Garber P.A., Estrada A., Bicca-Marques J.C. \& Heymann E.W. (eds) South American Primates, Developments in Primatology: Progress and Prospects: 55-68. Springer-Verlag, New York.

Olson D.M., Dinerstein E., Wikramanayake E.D., Burgess N.D., Powell G.V.N., Underwood E.C., d'Amico J.A., Itoua I., Strand H.E., Morrison J.C., Loucks C.J., Allnutt T.F., Ricketts T.H., Kura Y., Lamoreux J.F., Wettengel W.W., Hedao P. \& Kassem K.R. 2001. Terrestrial ecoregions of the world: A new map of life on Earth. BioScience 51 (11): 933-938.

https://doi.org/10.1641/0006-3568(2001)051\%5B0933:TEOTWA\%5D2.0.CO;2

Olsoufieff G. 1935. Note critique sur l'essai d'une phylogénie des lamellicornes coprophages. Entomologisches Nachrichtenblatt 9: 32-35.

Orsini L., Koivulehto H. \& Hanski I. 2007. Molecular evolution and radiation of dung beetles in Madagascar. Cladistics 23: 145-168. https://doi.org/10.1111/j.1096-0031.2006.00139.x

Pacheco T.L. \& Vaz-de-Mello F.Z. 2017. Rediscovery of the Neotropical genus Paracryptocanthon Howden \& Cook, 2002 (Coleoptera: Scarabaeidae: Scarabaeinae) in the Brazilian Atlantic Forest. Annales de la Société entomologique de France (N.S.) 53 (2): 99-105.

https://doi.org/10.1080/00379271.2017.1308809 
Pacheco T.L. \& Vaz-de-Mello F.Z. 2020. A taxonomic revision of Paracanthon Balthasar, 1938 (Coleoptera, Scarabaeidae, Scarabaeinae). Insect Systematics \& Evolution (online): 1-52. https://doi.org/10.1163/1876312X-00001042

Paul D., Kamenetsky V.S., Hofmann A.W. \& Stracke A. 2007. Compositional diversity among primitive lavas of Mauritius, Indian Ocean: Implications for mantle sources. Journal of Volcanology and Geothermal Research 164 (1-2): 76-94. https://doi.org/10.1016/j.jvolgeores.2007.04.004

Paulian R. 1938. Contribution a l'étude des canthonides américans [Coleopt. Lamellic.]. Annales de la Société entomologique de France 107: 213-296.

Paulian R. 1939. Contribution à l'étude des canthonides américains [Coleopt. Lamellic.] (suite et fin). Annales de la Société entomologique de France 108: 1-40.

Paulsen M.J. \& Hawks D.C. 2014. A review of the primary types of the Hawaiian stag beetle genus Apterocyclus Waterhouse (Coleoptera, Lucanidae, Lucaninae), with the description of a new species. Zookeys 433: 77-88. https://doi.org/10.3897/zookeys.433.8022

Peck S.B. 2006. The Beetles of the Galápagos Islands, Ecuador: Evolution, Ecology, and Diversity (Insecta: Coleoptera). NRC Research Press, Ottawa.

Pereira F.S. \& Martínez A. 1956. Os gêneros de Canthonini americanos (Col. Scarabaeidae). Revista brasileira de Entomologia 6: 91-192.

Péringuey L. 1901. Descriptive catalogue of the Coleoptera of South Africa. Transactions of the South African Philosophical Society 12: 1-563.

Philips T.K. 2016. Phylogeny of the Oniticellini and Onthophagini dung beetles (Scarabaeidae, Scarabaeinae) from morphological evidence. Zookeys 579: 9-57.

https://doi.org/10.3897/zookeys.579.6183

Philips T.K. \& Bell K.L. 2008. Attavicinus, a new generic name for the mymecophilous dung beetle Liatongus monstrosus (Scarabaeidae: Scarabaeinae). The Coleopteristis Bulletin (62) 1: 67-81.

https://doi.org/10.1649/984.1

Philips T.K. \& Ivie M.A. 2008. Seven new species of Canthochilum Chapin from Hispaniola (Coleoptera: Scarabaeidae: Scarabaeinae). Zootaxa 1730: 27-42.

Philips T.K., Scholtz C.H. \& Ocampo F.C. 2002. A phylogenetic analysis of the Eucraniini (Coleoptera: Scarabaeidae: Scarabaeinae). Insect Systematics \& Evolution 33: 241-252.

https://doi.org/10.1163/187631202X00145

Philips T.K., Pretorius E. \& Scholtz C.H. 2004a. A phylogenetic analysis of dung beetles (Scarabaeinae: Scarabaeidae): unrolling an evolutionary history. Invertebrate Systematics 18: 53-88. https://doi.org/10.1071/IS03030

Philips T.K., Edmonds W.D. \& Scholtz C.H. 2004b. A phylogenetic analysis of the New World tribe Phanaeini (Coleoptera: Scarabaeidae: Scarabaeinae): Hypotheses on relationships and origins. Insect Systematics \& Evolution 35: 43-63. https://doi.org/10.1163/187631204788964664

Poux C., Chevret P., Huchon D., de Jong W.W. \& Douzery E.J.P. 2006. Arrival and diversification of caviomorph rodents and platyrrhine primates in South America. Systematic Biology 55 (2): 228-244. https://doi.org/10.1080/10635150500481390

Quammen D. 1996. The Song of the Dodo. Island Biogeography in an Age of Extinctions. Scribner, New York.

de Queiroz A. 2005. The resurrection of oceanic dispersal in historical biogeography. Trends in Ecology and Evolution 20 (2): 68-73. https://doi.org/10.1016/j.tree.2004.11.006 
CUPELLO M. et al., Systematics of Streblopus and dung beetle biogeography

de Queiroz A. 2014. The Monkey's Voyage: How Improbable Journeys Shaped the History of Life. Basic Books, New York.

Raine E.H., Gray C.L., Mann D.J. \& Slade E.M. 2019. Tropical dung beetle morphological traits predict functional traits and show intraspecific differences across land uses. Ecology and Evolution 8 (17): 8686-8696. https://doi.org/10.1002/ece3.4218

Ratcliffe B.C. 2014. A new genus and species of Dynastinae (Coleoptera: Scarabaeidae) from the Galápagos Islands, Ecuador, other new species of Cyclocephalini, Pentodontini, and Phileurini from South America, and a revised key to the genera of the New World Pentodontini. The Coleopterists Bulletin 68 (4): 663-680. https://doi.org/10.1649/0010-065X-68.4.663

Ratcliffe B.C., Jameson M.L., Figueroa L., Cave R.D., Paulsen M.J., Cano E.B., Beza-Beza C., Jimenez-Ferbans L. \& Reyes-Castillo P. 2015. Beetles (Coleoptera) of Peru: A survey of the families. Scarabaeoidea. Journal of the Kansas Entomological Society 88 (2): 186-207.

https://doi.org/10.2317/kent-88-02-186-207.1

Renner S. 2004. Plant dispersal across the tropical Atlantic by wind and sea currents. International Journal of Plant Sciences 165 (Suppl. 4): S23-S33. https://doi.org/10.1086/383334

Ritsema C. 1888. Lijst der entomologische geschriften van Mr. J.W. van Lansberge, gevolgd door eene opgave der daarin beschreven nieuwe geslachten, ondergeslachten en soorten. Tijdschrift voor Entomologie 31: 201-234. Available from https://biodiversitylibrary.org/page/10853215 [accessed 7 Jan. 2020].

Rossini M. \& Vaz-de-Mello F.Z. 2015. Areview of the genus Chalcocopris Burmeister, 1846 (Coleoptera: Scarabaeidae: Scarabaeinae), with description of a new species. Zootaxa 3920 (2): 291-300.

https://doi.org/10.11646/zootaxa.3920.2.5

Rossini M. \& Vaz-de-Mello F.Z. 2017. A taxonomic review of the genus Isocopris Pereira and Martínez, 1960 (Coleoptera: Scarabaeidae: Scarabaeinae), with description of a new Brazilian species. Journal of Natural History 51 (19-20): 1091-1117. https://doi.org/10.1080/00222933.2017.1319517

Rossini M. \& Vaz-de-Mello F.Z. In press. A review of the mamillatus group with description of the new dung beetle Dichotomius (Dichotomius) gandinii sp. nov. from western Amazonia (Coleoptera: Scarabaeidae: Scarabaeinae). Austral Entomology.

Rossini M., Vaz-de-Mello F.Z. \& Zunino M. 2018. A taxonomic revision of the New World Onthophagus Latreille, 1801 (Coleoptera: Scarabaeidae: Scarabaeinae) of the osculatii species-complex, with description of two new species from South America. Journal of Natural History 52 (9-10): 541-586. https://doi.org/10.1080/00222933.2018.1437230

Rowe D.L., Dunn K.A., Adkins R.M. \& Honeycutt R.L. 2010. Molecular clocks keep dispersal hypotheses afloat: Evidence for trans-Atlantic rafting by rodents. Journal of Biogeography 37: 305-324. https://doi.org/10.1111/j.1365-2699.2009.02190.x

Sawaris L., Cupello M. \& Vaz-de-Mello F.Z. 2019. Taxonomic revision of the rare South American dung beetle genus Holocanthon Martínez et Pereira, 1956 (Coleoptera: Scarabaeidae: Scarabaeinae: Deltochilini). Annales Zoologici 69 (3): 561-574. https://doi.org/10.3161/00034541ANZ2019.69.3.006

Scholtz C.H. 2009. Section A. Evolution and ecological success of dung beetles. In: Scholtz C.H. Davis A.L.V. \& Kryger U. (eds) Evolutionary Biology and Conservation of Dung Beetles: 29-118. Pensoft Publishers, Sofia.

Scholtz C.H. \& Chown S.L. 1995. The evolution of habitat use and diet in the Scarabaeoidea: a phylogenetic approach. In: Pakaluk J. \& Ślipiński S.A. (eds) Biology, Phylogeny, and Classification of Coleoptera: Papers Celebrating the 80th Birthday of Roy A. Crowson: 355-374. Muzeum i Instytut Zoologii PAN, Warsaw. 
Scholtz C.H. \& Howden H.F. 1987. A revision of the African Canthonina (Coleoptera: Scarabaeidae: Scarabaeinae). Journal of the Entomological Society of Southern Africa 50 (1): 75-119.

Scholtz C.H., Davis A.L.V. \& Kryger U. 2009. Evolutionary Biology and Conservation of Dung Beetles. Pensoft Publishers, Sofia.

Schrago C.G. \& Russo C.A.M. 2003. Timing the origin of New World monkeys. Molecular Biology and Evolution 20 (10): 1620-1625. https://doi.org/10.1093/molbev/msg172

Scotese C.R. 2016. PALEOMAP: PaleoAtlas for GPlates and the PaleoData Plotter Porgram, PALEOMAP Project.

Available from: http://www.earthbyte.org/paleomap-paleoatlas-for-gplates/ [accessed 21 Sep. 2018].

Sick H. 1997. Ornitologia Brasileira. Editora Nova Fronteira, Rio de Janeiro.

Silva F.A.B. 2011. First record of Coprophanaeus bellicosus (Olivier) (Coleoptera, Scarabaeidae) in a "Brejo de Altitude" forest in northeastern Brazil: a historical biogeographical approach. Revista brasileira de Entomologia 55 (4): 615-617. https://doi.org/10.1590/S0085-56262011000400020

Silva F.A.B. \& Génier F. 2019. A new Peruvian species of Scybalocanthon Martínez, 1948 (Coleoptera, Scarabaeidae, Scarabaeinae, Deltochilini) and some remarkable intrapopulational variation in the endophallus of S. pinopterus (Kirsch, 1873). Zookeys 884: 69-80.

https://doi.org/10.3897/zookeys.884.39322

Silva F.A.B. \& Valois M. 2019. A taxonomic revision of the genus Scybalocanthon Martínez, 1948 (Coleoptera: Scarabaeidae: Scarabaeinae: Deltochilini). Zootaxa 4629 (3): 301-341.

https://doi.org/10.11646/zootaxa.4629.3.1

Silva F.A.B. \& Vaz-de-Mello F.Z. 2015. A revision of the genus Aphengium Harold, 1868 (Coleoptera: Scarabaeidae: Scarabaeinae: Ateuchini). Zootaxa 3955 (4): 505-520.

https://doi.org/10.11646/zootaxa.3955.4.3

Silva F.A.B., Louzada J. \& Vaz-de-Mello F.Z. 2015. A revision of the Deltochilum subgenus Aganhyboma Kolbe, 1893 (Coleoptera: Scarabaeidae: Scarabaeinae). Zootaxa 3925 (4): 451-504.

https://doi.org/10.11646/zootaxa.3925.4.1

Silvestro D., Tejedor M.F., Serrano-Serrano M.L., Loiseau O., Rossier V., Rolland J., Zizka A., Höhna S., Antonelli A. \& Salamin N. 2019. Early arrival and climatically-linked geographic expansion of New World monkeys from tiny African ancestors. Systematic Biology 68 (1): 78-92.

https://doi.org/10.1093/sysbio/syy046

Simonis A. 1981. Anoplodrepanus, nuovo genere di Oniticellini (Coleoptera, Scarabaeidae). Bollettino del Museo di Zoologia dell'Università di Torino 7: 87-94.

Simpson G.G. 1980. Splendid Isolation: The Curious History of South American Mammals. Yale University Press, New Haven, CT.

Smith K.G.V. 1987. Darwin's insects. Charles Darwin's “Entomological Notes”, with an introduction and comments. Bulletin of the British Museum (Natural History), Historical Series 14 (1): 1-141.

Sole C.L. \& Scholtz C.H. 2010. Did dung beetles arise in Africa? A phylogenetic hypothesis based on five gene regions. Molecular Phylogenetics and Evolution 56: 631-641.

https://doi.org/10.1016/j.ympev.2010.04.023

Sole C.L., Wirta H., Forgie S.A. \& Scholtz C.H. 2011. Origin of Madagascan Scarabaeini dung beetles (Coleoptera: Scarabaeidae): dispersal from Africa. Insect Systematics \& Evolution 42: 29-40.

https://doi.org/10.1163/187631211X552800 
CUPELLO M. et al., Systematics of Streblopus and dung beetle biogeography

Tarasov S. \& Dimitrov D. 2016. Multigene phylogenetic analysis redefines dung beetles relationships and classification (Coleoptera: Scarabaeidae: Scarabaeinae). BMC Evolutionary Biology 16 (257): 1-19. http://dx.doi.org/10.1186/s12862-016-0822-x

Tarasov S. \& Génier F. 2015. Innovative Bayesian and parsimony phylogeny of dung beetles (Coleoptera, Scarabaeidae, Scarabaeinae) enhanced by ontology-based partitioning of morphological characters. PLoS One 10 (3): 1-86. https://doi.org/10.1371/journal.pone.0116671

Tarasov S.I. \& Solodovnikov A.Y. 2011. Phylogenetic analyses reveal reliable morphological markers to classify mega-diversity in Onthophagini dung beetles (Coleoptera: Scarabaeidae: Scarabaeinae). Cladistics 27: 1-39. https://doi.org/10.1111/j.1096-0031.2011.00351.x

Tarasov S., Vaz-de-Mello F.Z., Krell F.-T. \& Dimitrov D. 2016. A review and phylogeny of Scarabaeinae dung beetle fossils (Coleoptera: Scarabaeidae: Scarabaeinae), with the description of two Canthochilum species from Dominican amber. PeerJ 4: e1988. https://doi.org/10.7717/peerj.1988

Tocco C., Dacke M. \& Byrne M. 2019. Eye and wing structure closely reflects the visual ecology of dung beetles. Journal of Comparative Physiology A 205 (2): 211-221.

https://doi.org/10.1007/s00359-019-01324-6

Trujillo-Arias N., Dantas G.P.M., Arbeláez-Cortés E., Naoki K., Gómez M.I., Santos F.R., Miyaki C.Y., Aleixo A., Tubaro P.L. \& Cabanne G.S. 2017. The niche and phylogeography of a passerine reveal the history of biological diversification between the Andean and the Atlantic forests. Molecular Phylogenetics and Evolution 112: 107-121. http://dx.doi.org/10.1016/j.ympev.2017.03.025

Trujillo-Arias N., Calderón L., Santos F.R., Miyaki C.Y., Aleixo A., Witt C.C., Tubaro P.L. \& Cabanne G.S. 2018. Forest corridors between the central Andes and the southern Atlantic Forest enabled dispersal and peripatric diversification without niche divergence in a passerine. Molecular Phylogenetics and Evolution 128: 221-232. https://doi.org/10.1016/j.ympev.2018.08.005

Valois M., Vaz-de-Mello F.Z. \& Silva F.A.B. 2015. A taxonomic review of the Neotropical genus Hansreia Halffter \& Martínez, 1977 (Coleoptera: Scarabaeidae: Scarabaeinae). Zootaxa 4027 (2): 205226. https://doi.org/10.11646/zootaxa.4027.2.2

Valois M., Vaz-de-Mello F.Z. \& Silva F.A.B. 2017. Taxonomic revision of the Dichotomius sericeus (Harold, 1867) species group (Coleoptera: Scarabaeidae: Scarabaeinae). Zootaxa 4277 (4): 503-530. https://doi.org/10.11646/zootaxa.4277.4.3

Van Lansberge J.W. 1874a. Description de quelques Lamellicornes Coprophages. Coleopterologische Hefte 12: 4-12. Available from https://biodiversitylibrary.org/page/25118460 [accessed 7 Jan. 2020].

Van Lansberge J.W. 1874b. Observations sur la classification des Lamellicornes Coprophages. Annales de la Société entomologique de Belgique 17: 177-193.

Available from https://biodiversitylibrary.org/page/12728027 [accessed 7 Jan. 2020].

Vaz-de-Mello F.Z. 2000. Estado atual de conhecimentos dos Scarabaeidae s. str. (Coleoptera: Scarabaeoidea) do Brasil. In: Martín-Piera F., Morrone J.J. \& Melic A. (eds) Hacia un Proyecto CYTED para el Inventario y Estimación de la Diversidad entomológica en Iberoamérica: PRIBES-2000. m3m: Monografias Tercer Milenio, Vol. 1: 183-195. Sociedad Entomológica Aragonesa (SEA), Zaragoza, Spain.

Vaz-de-Mello F.Z. 2007a. Revision and phylogeny of the dung beetle genus Zonocopris Arrow 1932 (Coleoptera: Scarabaeidae: Scarabaeinae), a phoretic of land snails. Annales de la Société entomologique de France (N.S.) 43 (2): 231-239. https://doi.org/10.1080/00379271.2007.10697516

Vaz-de-Mello F.Z. 2007b. Revisión taxonómica y Análisis filogenético de la Tribu Ateuchini (Coleoptera: Scarabaeidae: Scarabaeinae). PhD thesis, Instituto de Ecología, Xalapa, Mexico. 
Vaz-de-Mello F.Z. 2008. Synopsis of the new subtribe Scatimina (Coleoptera: Scarabaeidae: Scarabaeinae: Ateuchini), with descriptions of twelve new genera and review of Genieridium, new genus. Zootaxa 1955: 1-75.

Vaz-de-Mello F.Z. \& Cupello M. 2018. The type specimens of the New World dung beetles, Part I: On the species described in the genus Canthon Hoffmannsegg, 1817 (Coleoptera: Scarabaeidae: Scarabaeinae) by the German entomologist Adolf Schmidt (1856-1923). Spixiana 41 (1): 33-76.

Vaz-de-Mello F.Z. \& Grossi P.C. 2010. First report of Bolbites Harold (Scarabaeidae: Scarabaeinae: Phanaeini) in Brazil. The Coleopterists Bulletin 64 (3): 220.

https://doi.org/10.1649/0010-065X-64.3.220.6

Vaz-de-Mello F.Z. \& Halffter G. 2006. A new dung beetle genus with two new species from Chile (Coleoptera: Scarabaeidae: Scarabaeinae). Zootaxa 1193: 59-68.

Vaz-de-Mello F.Z., Edmonds W.D., Ocampo F.C. \& Schoolmeesters P. 2011. A multilingual key to the genera and subgenera of the subfamily Scarabaeinae of the New World (Coleoptera: Scarabaeidae). Zootaxa 2854: 1-73.

Vidal N., Azvolinsky A., Cruaud C. \& Hedges S.B. 2008. Origin of tropical American burrowing reptiles by transatlantic rafting. Biology Letters 4: 115-118. https://doi.org/10.1098/rsbl.2007.0531

Vidaurre T., Ledezma J. \& Vaz-de-Mello F.Z. 2009. Primer registro de Eudinopus dytiscoides (Schreibers, 1802) (Coleoptera: Scarabaeidae: Scarabaeinae: Canthonini) para Bolivia. Acta Zoológica Mexicaca (N.S.) 25 (1): 187-189.

Vieira M.K., Vaz-de-Mello F.Z. \& Silva F.A.B. 2019. A taxonomic revision of the Canthon subgenus Pseudepilissus Martínez, 1954 (Coleoptera: Scarabaeidae: Scarabaeinae). Insect Systematics \& Evolution (online): 1-57. https://doi.org/10.1163/1876312X-00001023

Vinson J. 1951. Les cas des sisyphes mauriciens (Insectes Coléoptères). Proceedings of the Royal Society of Arts and Sciences of Mauritius 1 (2): 105-122.

Vinson J. 1958. Catalogue of the Coleoptera of Mauritius and Rodriguez. Part II. The Mauritius Institute Bulletin 4 (2): 75-111.

Voelker G., Rohwer S., Outlaw D.C. \& Bowie R.C.K. 2008. Repeated trans-Atlantic dispersal catalysed a global songbird radiation. Global Ecology and Biogeography 18: 41-49.

https://doi.org/10.1111/j.1466-8238.2008.00423.x

Voloch C.M., Vilela J.F., Loss-Oliveira L. \& Schrago C.G. 2013. Phylogeny and chronology of the major lineages of New World hystricognath rodents: Insights on the biogeography of the Eocene/Oligocene arrival of mammals in South America. BMC Research Notes 6 (160): 1-9.

https://doi.org/10.1186/1756-0500-6-160

Vulcano M.A. \& Pereira F.S. 1964. Catalogue of the Canthonini (Col. Scarab.) inhabiting the Western Hemisphere. Entomologische Arbeiten aus dem Museum G. Frey 15 (2): 570-685. Available from https://biodiversitylibrary.org/page/45986646 [accessed 7 Jan. 2020].

Vulcano M.A. \& Pereira F.S. 1967. Sinopse dos Passalidae e Scarabaeidae s. str. da região amazônica (Insecta, Coleoptera). Atas do Simpósio sobre a Biota Amazônica 5 (Zoologia): 533-603.

Whiting A.S., Sites J.W. Jr, Pellegrino K.C.M. \& Rodrigues M.T. 2006. Comparing alignment methods for inferring the history of the New World lizard genus Mabuya (Squamata: Scincidae). Molecular Phylogenetics and Evolution 38: 719-730. https://doi.org/10.1016/j.ympev.2005.11.011

Williams D.M. \& Ebach M.C. 2008. Foundations of Systematics and Biogeography. Springer, New York.

Wilson E.O. 1994. Naturalist. Island Press, Washington DC. 
CUPELLO M. et al., Systematics of Streblopus and dung beetle biogeography

Wirta H. \& Montreuil O. 2008. Evolution of the Canthonini Longitarsi (Scarabaeidae) in Madagascar. Zoologica Scripta 37: 651-663. https://doi.org/10.1111/j.1463-6409.2008.00352.x

Wirta H., Orsini L. \& Hanski I. 2008. An old adaptive radiation of forest dung beetles in Madagascar. Molecular Phylogenetics and Evolution 47 (3): 1076-1089. https://doi.org/10.1016/j.ympev.2008.03.010

WWF [World Wildlife Fund]. 2006. WildFinder: Online database of species distributions, ver. Jan-06. Available from https://www.worldwildlife.org/pages/wildfinder-database [accessed 19 Sep. 2018].

Yoder A.D. \& Nowak M.D. 2006. Has vicariance or dispersal been the predominant biogeographic force in Madagascar? Only time will tell. Annual Review of Ecology, Evolution, and Systematics 37: 405-431. https://doi.org/10.1146/annurev.ecolsys.37.091305.110239

Yonezawa T., Segawa T., Mori H., Campos P.F., Hongoh, Y., Endo H., Akiyoshi A., Kohno N., Nishida S., Wu J., Jin H., Adachi J., Kishino H., Kurokawa K., Nogi Y., Tanabe H., Mukoyama H., Yoshida K., Rasoamiaramanana A., Yamagishi S., Hayashi Y., Yoshida A., Koike H., Akishinonomiya F., Willerslev E., Hasegawa M. 2017. Phylogenomics and morphology of extinct paleognaths reveal the origin and evolution of the ratites. Current Biology 27 (1): 68-77. https://doi.org/10.1016/j.cub.2016.10.029

Zachos J., Pagani M., Sloan L., Thomas E. \& Billups K. 2001. Trends, rhythms, and aberrations in global climate 65 Ma to present. Science 292 (5517): 686-993. https://doi.org/10.1126/science. 1059412

Zunino M. 1972. Revisione delle specie paleartiche del genere Onthophagus Latr. (Coleoptera, Scarabaeoidea). I. - Il sottogenere Euonthophagus Balth. Bollettino del Museo di Zoologia dell'Università di Torino 1: 1-28.

Zunino M. 1982. Aspectos taxonomicos y biogeográficos del poblamiento americano de Oniticellini (Coleoptera, Scarabaeidae). In: Salinas P.J. (ed.) Zoologia Neotropical: Actas del VIII Congreso Latinoamericano de Zoología 2 1083-1089. Producciones Alfa, Mérida, Mexico.

Manuscript received: 9 April 2019

Manuscript accepted: 21 November 2019

Published on: 11 February 2020

Topic editor: Gavin Broad

Section editor: Max Barclay

Desk editor: Danny Eibye-Jacobsen

Printed versions of all papers are also deposited in the libraries of the institutes that are members of the EJT consortium: Muséum national d'histoire naturelle, Paris, France; Meise Botanic Garden, Belgium; Royal Museum for Central Africa, Tervuren, Belgium; Royal Belgian Institute of Natural Sciences, Brussels, Belgium; Natural History Museum of Denmark, Copenhagen, Denmark; Naturalis Biodiversity Center, Leiden, the Netherlands; Museo Nacional de Ciencias Naturales-CSIC, Madrid, Spain; Real Jardín Botánico de Madrid CSIC, Spain; Zoological Research Museum Alexander Koenig, Bonn, Germany; National Museum, Prague, Czech Republic. 